\title{
Recommendations for the design, calculation, installation and inspection of wind-turbine foundations
}

\section{Members of the Working Group "Wind turbine foundations"}

Chair

Berthelot Patrick Bureau Veritas

Secretaries

Glandy Michel

Soletanche-Bachy-Pieux

Lamadon Thierry

Bureau Veritas

Authors

Aguado Pascal

Carpinteiro Luis

Apave

Socotec

Dano Christophe

Ecole Centrale Nantes

Durand Daniel

Bureau Veritas

Durand Frédéric

Fugro

Gauthey J-Robert

Spie Fondations

Jandel Eric

Fondasol

Lambert Serge

Martin Alexander

Keller

CTE

Plomteux Cyril

Ménard

Thorel Luc

LCPC

With contribution from

Antoinet Eric

Antéa

Bersch Matias

CTE

Bourne Gilles

Alios

Bretelle Sylvie

De Muynck Pascale

Cathie-Associates

Denois Thierry

EDF-EN

Le Kouby Alain

EDF-EN

Liausu Philippe

LCPC

Mazaré Bruno

Ménard

$\mathrm{Pal}$ Olivier

Egis

Reboul Michaël

Eiffage

Terrasol

With recommendations from

Marburger

Nordex

Niedermowwe Nills

Puech Alain

Enercon

Remillon Vincent

SOLCYP

Schacknies Meik

Repower

Enercon 


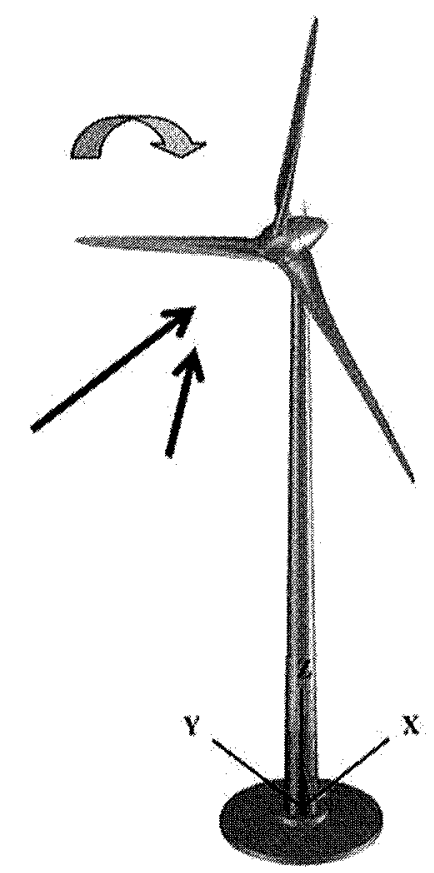

\section{Notations and Units}

\section{Latin Notations}

\begin{tabular}{|c|c|c|}
\hline$A_{p}$ & Cross-section of inclusion or column & {$\left[\mathrm{m}^{2}\right]$} \\
\hline$A_{s w}$ & Surface area of shear force reinforcement & {$\left[\mathrm{m}^{2}\right]$} \\
\hline B & Foundation width "compressed soil" & {$[\mathrm{m}]$} \\
\hline $\mathrm{C}$ & $=2 / \mathrm{n} / \varnothing_{2} / \mathrm{K}_{\mathrm{pv}} / \varnothing_{2} \mathrm{~K}_{\mathrm{ph}} \varnothing_{1} \mathrm{lo}^{3}$ & \\
\hline$C^{\prime}$ & Effective cohesion & {$[\mathrm{Pa}]$} \\
\hline $\mathrm{C}_{\max }$ & Ratio taking required concrete consistency into account & \\
\hline $\mathrm{d}$ & $\mathrm{d}=1-\mathrm{nc} /(1+\mathrm{nc})$ & \\
\hline $\mathrm{d}_{\mathrm{x}}$ & Solid grain diameter at $x$ percent passing & {$[\mathrm{m}]$} \\
\hline $\mathrm{d}_{1}$ & Failure mechanism length & {$[\mathrm{m}]$} \\
\hline $\mathrm{d}_{2}$ & Failure mechanism length & {$[\mathrm{m}]$} \\
\hline $\mathrm{e}$ & Vertical load eccentricity $=\mathrm{M} / \mathrm{V}$ & {$[\mathrm{m}]$} \\
\hline $\mathrm{E}$ & Young's modulus (for deformations between $10^{-3}$ and $10^{-4}$ ) & {$[\mathrm{Pa}]$} \\
\hline $\mathrm{E}_{\mathrm{c}}$ & Spherical modulus (Ménard) & {$[\mathrm{Pa}]$} \\
\hline $\mathrm{E}_{\mathrm{d}}$ & Deviatoric modulus (Ménard) & {$[\mathrm{Pa}]$} \\
\hline $\mathrm{E}_{\mathrm{eq}}$ & Equivalent deformation modulus & {$[\mathrm{Pa}]$} \\
\hline$E_{\max }$ & Young's modulus for deformation of about $10^{-6}$ & {$[\mathrm{~Pa}]$} \\
\hline$E_{\text {oed }}$ & Oedometric modulus & {$[\mathrm{Pa}]$} \\
\hline$E_{\text {yst }}$ & Young's modulus for deformation of about $10^{-2}$ & {$[\mathrm{~Pa}]$} \\
\hline $\mathrm{E}_{\mathrm{M}}$ & Modulus determined from a standardized Ménard pressuremeter test & {$[\mathrm{Pa}]$} \\
\hline $\mathrm{E}_{\mathrm{mEq}}$ & Harmonic mean $\mathrm{E}_{\mathrm{M}}$ & {$[\mathrm{Pa}]$} \\
\hline EV1 & Plate loading test: modulus of the first load & {$[\mathrm{Pa}]$} \\
\hline $\mathrm{EV} 2$ & Plate loading test: modulus of the second load & {$[\mathrm{Pa}]$} \\
\hline
\end{tabular}




\begin{tabular}{|c|c|c|}
\hline $\mathrm{E}_{y}$ & Young's modulus for rigid-component material & {$[\mathrm{Pa}]$} \\
\hline$f_{c}^{*}$ & Characteristic value for concrete or grout strength & {$[\mathrm{Pa}]$} \\
\hline$f_{c d}$ & Inclusion compressive design strength & {$[\mathrm{Pa}]$} \\
\hline$f_{c j}$ & Compressive strength of rigid component material & {$[\mathrm{Pa}]$} \\
\hline$f_{c k}$ & Characteristic concrete compressive strength measured on cylinders at 28 days & {$[\mathrm{Pa}]$} \\
\hline$f_{c k}(t)$ & Characteristic concrete compressive strength measured on cylinders at time $t$ & {$[\mathrm{~Pa}]$} \\
\hline$f_{c k}^{*}$ & Characteristic inclusion concrete, grout or mortar compressive strength & {$[\mathrm{Pa}]$} \\
\hline$f_{\text {ct }}$ & Concrete tensile strength & {$[\mathrm{Pa}]$} \\
\hline$f_{\text {ctol }}$ & Concrete design tensile strength & {$[\mathrm{Pa}]$} \\
\hline $\mathrm{f}_{\text {ctk0.05 }}$ & $5 \%$ fractile of characteristic concrete tensile strength & {$[\mathrm{Pa}]$} \\
\hline$f_{\text {ctm }}$ & Mean value for concrete direct tensile strength & {$[\mathrm{Pa}]$} \\
\hline$f_{\text {cvd }}$ & Concrete shear and compressive design strength & {$[\mathrm{Pa}]$} \\
\hline$f_{\text {gwd }}$ & Steel design strength $\left(=\mathrm{f}_{\mathrm{e}} / \gamma_{\mathrm{s}}\right)$ at ULS & {$[\mathrm{Pa}]$} \\
\hline$f_{s}$ & Local unit sleeve friction (using CPT) & {$[\mathrm{Pa}]$} \\
\hline$f_{e}$ & Material elastic limit for metal inclusions & {$[\mathrm{Pa}]$} \\
\hline $\mathrm{F}_{\text {water }}$ & Vertical heave force exerted on foundation slab by water & {$[\mathrm{N}]$} \\
\hline $\mathrm{F}_{\mathrm{z}}$ or $\mathrm{V}$ & Vertical compressive force exerted on foundation slab & {$[\mathrm{N}]$} \\
\hline $\mathrm{F}_{\mathrm{zULS}}$ & Compression & [N] \\
\hline $\mathrm{F}_{\text {zmin }}$ & Minimum vertical compressive load transmitted to soil by the footing & {$[\mathrm{N}]$} \\
\hline$\gamma$ or $\gamma_{0}$ & Earth's gravity acceleration & {$\left[\mathrm{m} / \mathrm{s}^{2}\right]$} \\
\hline G & Shear modulus (for deformations between $10^{-3}$ and $10^{-4}$ ) & {$[\mathrm{Pa}]$} \\
\hline $\mathrm{G}_{\text {coldyn }}$ & Shear modulus at $10^{-4}$ in stone columns & {$[\mathrm{Pa}]$} \\
\hline $\mathrm{G}_{\text {eq }}$ & Equivalent shear modulus of the soil-column system for deformation from $10^{-3}$ to $10^{-4}$ & {$[\mathrm{~Pa}]$} \\
\hline $\mathrm{G}_{\max }$ & Shear modulus at $10^{-6}$ distortion & [Pa] \\
\hline $\mathrm{G}_{\mathrm{dyneq}}$ & Equivalent dynamic shear modulus & {$[\mathrm{Pa}]$} \\
\hline$G_{\text {soildyn }}$ & Shear modulus at $10^{-4}$ in soil around stone columns & {$[\mathrm{Pa}]$} \\
\hline h & Foundation slab embedding depth & {$[\mathrm{m}]$} \\
\hline $\mathrm{H}_{1}$ & Minimum footing downward displacement & {$[\mathrm{m}]$} \\
\hline $\mathrm{H}_{1}$ & Failure mechanism length & {$[\mathrm{m}]$} \\
\hline $\mathrm{H}_{2}$ & Maximum footing downward displacement & {$[\mathrm{m}]$} \\
\hline $\mathrm{h}_{2}$ & Failure mechanism length & {$[\mathrm{m}]$} \\
\hline$h_{i}$ & Shear force in head of imaginary platform column to the right of the inclusion & {$[\mathrm{N}]$} \\
\hline$h_{\mathrm{r}}$ & Minimum load transfer platform thickness & {$[\mathrm{m}]$} \\
\hline$h_{\mathrm{s}}$ & Shear force applied to load-transfer platform in footing underside & {$[\mathrm{m}]$} \\
\hline $\mathrm{H}$ & Horizontal stress exerted on foundation slab & {$[N]$} \\
\hline $\mathrm{H}_{\mathrm{ULS}}$ & Horizontal stress exerted on foundation slab at ULS & {$[N]$} \\
\hline $\mathrm{H}_{\text {plat }}$ & Load-transfer platform thickness & [m] \\
\hline$I_{8}, i_{\beta}, i_{e}$ & Correction factors for a shallow foundation & \\
\hline$i_{\delta \beta}$ & Bearing reduction factor, the combination of an inclined load and a slope & \\
\hline I & Footing inertia & {$\left[\mathrm{m}^{4}\right]$} \\
\hline I & Pile inertia & {$\left[\mathrm{m}^{4}\right]$} \\
\hline I & Rigid inclusion inertia & {$\left[\mathrm{m}^{4}\right]$} \\
\hline
\end{tabular}




\begin{tabular}{|c|c|c|}
\hline $\mathrm{J}$ & $\mathrm{n} \varnothing_{2}^{2} / 8$ & {$\left[\mathrm{~m}^{2}\right]$} \\
\hline $\mathrm{k}_{1}$ & Boring method function coefficient & {$[-]$} \\
\hline $\mathrm{k}_{2}$ & Slendering function coefficient & {$[-]$} \\
\hline $\mathrm{k}_{3}$ & Type of structure function coefficient & {$[-]$} \\
\hline $\mathrm{k}_{\mathrm{c}}$ & Bearing ratio & {$[-]$} \\
\hline $\mathrm{k}_{\mathrm{p}}$ & Bearing ratio & {$[--]$} \\
\hline $\mathrm{k}_{v}$ & Vertical stiffness & {$\left[\mathrm{N} / \mathrm{m}^{2} / \mathrm{m}\right]$} \\
\hline $\mathrm{K}_{\mathrm{ph}}$ & Horizontal stiffness of inclusion or pile head & {$[\mathrm{N} / \mathrm{m}]$} \\
\hline $\mathrm{K}_{\mathrm{pv}}$ & Vertical stiffness of inclusion or pile & {$[\mathrm{N} / \mathrm{m}]$} \\
\hline $\mathrm{K}_{\mathrm{x}} \mathrm{K}_{\mathrm{y}} \mathrm{K}_{\mathrm{z}}$ & Minimum required horizontal thickness for foundation slab according to axes $x x, y y$ and $z z$ & {$[\mathrm{~N} / \mathrm{m}]$} \\
\hline $\mathrm{K}_{\mathrm{h}}$ & Foundation reaction coefficient & {$[\mathrm{N} / \mathrm{m}]$} \\
\hline $\mathrm{K}_{\mathrm{s}}$ & Soil stiffness & {$[\mathrm{N} / \mathrm{m}]$} \\
\hline $\mathrm{K}_{\mathrm{v}}$ & Soil vertical stiffness & {$[\mathrm{N} / \mathrm{m}]$} \\
\hline $\mathrm{K}_{v s}$ & Static vertical stiffness $\mathrm{K}_{\mathrm{vs}}=\mathrm{q} / \mathrm{w}$ & {$[\mathrm{N} / \mathrm{m}]$} \\
\hline $\mathrm{K}_{\varphi}$ & Rotational stiffness & {$[\mathrm{Nm} / \mathrm{rad}]$} \\
\hline $\mathrm{K}_{\text {} \subset \mathrm{CT}}$ & ST (Short-term) rotational stiffness & {$[\mathrm{Nm} / \mathrm{rad}]$} \\
\hline $\mathrm{K}_{\text {} \mathrm{LT}}$ & LT (Long-term) rotational stiffness & {$[\mathrm{Nm} / \mathrm{rad}]$} \\
\hline $\mathrm{K}_{\varphi \mathrm{NS}}$ & Rotational stiffness when foundation slab is not heaved & {$[\mathrm{Nm} / \mathrm{rad}]$} \\
\hline$K_{p, d y n}$ & Rotational stiffness for small deformations (from $10^{-5}$ to $10^{-3}$ ) & {$[\mathrm{Nm} / \mathrm{rad}]$} \\
\hline $\mathrm{L}$ & Foundation length (inclusion, pile or stone column) & {$[\mathrm{m}]$} \\
\hline $\mathrm{l}_{\mathrm{o}}$ & Transfer length & {$[\mathrm{m}]$} \\
\hline $\mathrm{M}$ & Overturning moment applied on foundation slab & {$[\mathrm{Nm}]$} \\
\hline $\mathrm{M}_{\mathrm{i}}$ & Maximum moment in pile head & {$[\mathrm{Nm}]$} \\
\hline$M^{\prime}$ & $=M_{x y}-n \cdot M_{i}$ & {$[\mathrm{Nm}]$} \\
\hline $\mathrm{M}_{\mathrm{ULS}}$ & Moment at ULS & {$[\mathrm{Nm}]$} \\
\hline M & Overturning moment & {$[\mathrm{Nm}]$} \\
\hline $\mathrm{m}^{\prime}$ & $=(\mathrm{n}-1) / \mathrm{n}$ & {$[-]$} \\
\hline$n$ & Porosity & {$[-]$} \\
\hline $\mathrm{n}$ & Improvement factor $=\sigma_{\text {appl }} / \sigma_{\text {soil }}$ & \\
\hline $\mathrm{n}$ & Number of columns under reference surface $S_{\text {ref }}$ & {$[-]$} \\
\hline $\mathrm{n}$ & Number of inclusions or piles & {$[-]$} \\
\hline $\mathrm{Nc}$ & Cohesion resistance & {$[-]$} \\
\hline $\mathrm{Nq}$ & Depth resistance & {$[-]$} \\
\hline $\mathrm{p}_{\mathrm{f}}$ & Boring pressure & {$[\mathrm{Pa}]$} \\
\hline $\mathrm{p}_{1}$ & Pressuremeter limit pressure & {$[\mathrm{Pa}]$} \\
\hline $\mathrm{p}_{1^{*}}$ & Pressuremeter net limit pressure & {$[\mathrm{Pa}]$} \\
\hline $\mathrm{p}_{\mathrm{Ici}}$ & Design limit pressure $p_{\mathrm{lci}}=\mathrm{p}_{\mathrm{li}}{ }^{*}\left[\left(1+\alpha_{\mathrm{j}}\right)^{2}\right]$ & {$[\mathrm{Pa}]$} \\
\hline $\mathrm{p}_{\mathrm{le}}$ & Equivalent limit pressure & {$[\mathrm{Pa}]$} \\
\hline $\mathrm{p}_{\mathrm{le}}^{*}$ & Equivalent net limit pressure & {$[\mathrm{Pa}]$} \\
\hline $\mathrm{p}_{\mathrm{li}}$ & Limit pressure measured in " $\mathrm{i}$ " section & {$[\mathrm{Pa}]$} \\
\hline $\mathrm{p}_{\operatorname{lmax}}$ & Maximum measured limit pressure & {$[\mathrm{Pa}]$} \\
\hline $\mathrm{p}_{\text {Imin }}$ & Minimum measured limit pressure & {$[\mathrm{Pa}]$} \\
\hline
\end{tabular}




\begin{tabular}{|c|c|c|}
\hline$q$ & $K_{v s}=q / w$ & {$[\mathrm{~Pa}]$} \\
\hline $\mathrm{q}_{0}^{\prime}$ & $=\rho^{\prime} \times \gamma \times z$ & {$[\mathrm{~Pa}]$} \\
\hline $\mathrm{q}_{1}$ & Stress in load-transfer platform underside (to the right of the inclusion) & {$[\mathrm{Pa}]$} \\
\hline $\mathrm{q}_{2}$ & Stress in load-transfer platform underside (to the right of the soil) & {$[\mathrm{Pa}]$} \\
\hline $\mathrm{q}_{\mathrm{a}}$ & Stress in stone columns & {$[\mathrm{Pa}]$} \\
\hline $\mathrm{q}_{\text {app }}^{\prime}$ & Mean stress applied to soil over mesh & {$[\mathrm{Pa}]$} \\
\hline$q_{c}$ & Tip resistance (or cone resistance) & {$[\mathrm{Pa}]$} \\
\hline $\mathrm{q}_{\mathrm{ce}}$ & Equivalent tip (or cone) resistance & {$[\mathrm{Pa}]$} \\
\hline $\mathrm{q}_{\mathrm{cci}}$ & "i" section design tip resistance & {$[\mathrm{Pa}]$} \\
\hline $\mathrm{q}_{\mathrm{ci}}$ & "i" section tip resistance & {$[\mathrm{Pa}]$} \\
\hline $\mathrm{q}_{\mathrm{cEq}}$ & Harmonic mean of $\mathrm{q}_{\mathrm{c}}$ & {$[\mathrm{Pa}]$} \\
\hline $\mathrm{q}_{\mathrm{cm}}$ & Mean tip resistance & {$[\mathrm{Pa}]$} \\
\hline$q_{\text {col }}$ & Stress in columns & {$[\mathrm{Pa}]$} \\
\hline$q_{d}$ & Tip resistance with dynamic penetrometer & {$[\mathrm{Pa}]$} \\
\hline $\mathrm{q}_{\text {plat }}$ & Allowable stress in load transfer plateform at inclusion head level & {$[\mathrm{Pa}]$} \\
\hline $\mathrm{q}_{\mathrm{p}}$ & Soil bearing capacity under footing & [Pa] \\
\hline$q_{p}$ & Stress transmitted to inclusion by load-transfer platform & [Pa] \\
\hline $\mathrm{q}_{\mathrm{p} ; \mathrm{l}}$ & Inclusion tip unit resistance & {$[\mathrm{Pa}]$} \\
\hline $\mathrm{q}_{\mathrm{r}}$ & Vertical failure stress $\mathrm{q}_{\mathrm{r}}$ of an isolated column & {$[\mathrm{Pa}]$} \\
\hline $\mathrm{q}_{\mathrm{re}}$ and $\mathrm{q}_{\mathrm{rp}}$ & $\begin{array}{l}\text { See definitions } \S 5.4 \text { in the "Recommandations colonnes ballastées du CFMS (2011)" } \\
\text { (stone-column recommendations) }\end{array}$ & {$[\mathrm{Pa}]$} \\
\hline $\mathrm{q}_{\text {ref }}$ & Maximum stress applied on soil & {$[\mathrm{Pa}]$} \\
\hline$q_{\text {refSLS }}$ & SLS design stress & {$[\mathrm{Pa}]$} \\
\hline $\mathrm{q}_{\text {refuLS }}$ & ULS design stress & {$[\mathrm{Pa}]$} \\
\hline $\mathrm{q}_{\mathrm{S}}$ & Ultimate unit skin friction & {$[\mathrm{Pa}]$} \\
\hline $\mathrm{q}_{\mathrm{S}}$ & Stress under footing & {$[\mathrm{Pa}]$} \\
\hline $\mathrm{q}_{\mathrm{s}}$ & Stress transmitted to compressible soil by loadtransfer platform & {$[\mathrm{Pa}]$} \\
\hline $\mathrm{q}_{\mathrm{S} ; 1}$ & Failure stress under footing & {$[\mathrm{Pa}]$} \\
\hline$q_{\text {soil }}$ & Overall soil bearing capacity (for stone columns) & {$[\mathrm{Pa}]$} \\
\hline$Q_{\text {col }}$ & Maximum stress value in stone column & {$[N]$} \\
\hline$Q_{i}$ & Load value for imaginary column in loadtransfer platform to the right of the inclusion & {$[N]$} \\
\hline$Q_{\max }$ & Maximum vertical compressive force in the vertical rigid component, induced by overturning moment & {$[\mathrm{N}]$} \\
\hline $\mathrm{Q}_{\mathrm{p}}$ & Vertical load per inclusion under central load & {$[\mathrm{N}]$} \\
\hline$Q_{\text {sem }}$ & Compressive load applied to the soil on footing underside & {$[\mathrm{N}]$} \\
\hline $\mathrm{r}$ & Radius of equivalent circular foundation slab with same section as wind-turbine foundation slab & {$[\mathrm{m}]$} \\
\hline $\mathrm{r}^{*}$ & Radius of equivalent circular foundation slab with same section as completely compressed surface area & \\
\hline$R_{b}$ & Inclusion tip bearing & {$[\mathrm{N}]$} \\
\hline $\mathrm{R}_{\mathrm{f}}$ & Friction ratio & {$[-]$} \\
\hline $\mathrm{R}_{\mathrm{s}}$ & Inclusion friction bearing & {$[\mathrm{N}]$} \\
\hline$s_{t}$ & Coil to coil spacing & {$[\mathrm{m}]$} \\
\hline $\mathrm{s}$ & Settlement & {$[\mathrm{m}]$} \\
\hline$S$ & Pile full section & {$\left[\mathrm{m}^{2}\right]$} \\
\hline $\mathrm{S}_{\text {col }}$ & Column compressed section & {$\left[\mathrm{m}^{2}\right]$} \\
\hline
\end{tabular}




\begin{tabular}{|c|c|c|}
\hline $\mathrm{S}_{\text {comp }}$ & Real compressed section under footing & {$\left[\mathrm{m}^{2}\right]$} \\
\hline $\mathrm{S}_{\mathrm{c}}$ & Ground slab cross section & {$\left[\mathrm{m}^{2}\right]$} \\
\hline $\mathrm{S}_{\mathrm{sem}}$ & Total surface area of footing & {$\left[\mathrm{m}^{2}\right]$} \\
\hline $\mathrm{S}_{\text {mesh }}$ & Mesh surface area & {$\left[\mathrm{m}^{2}\right]$} \\
\hline $\mathrm{S}_{\mathrm{r}}$ & Saturation level & {$[-]$} \\
\hline$S_{\text {ref }}$ & Compressed surface area of half-moon & {$\left[\mathrm{m}^{2}\right]$} \\
\hline $\mathrm{T}(\mathrm{z})$ & Mobilizable friction & {$[N]$} \\
\hline $\mathrm{v}$ & See $J / v$ and equals $\Phi_{2} / 2$ & {$[\mathrm{~m}]$} \\
\hline$V_{i}$ & Maximum shear force in rigid inclusion & {$[\mathrm{m} / \mathrm{s}]$} \\
\hline $\mathrm{V}_{\mathrm{P}}$ & Compression wave velocity (called primary) & {$[N]$} \\
\hline $\mathrm{V}_{\mathrm{Rd}, \mathrm{s}}$ & Allowable shear force of a pile or rigid inclusion at SLS, according to steel installed & {$[\mathrm{N}]$} \\
\hline $\mathrm{V}_{\text {rdmax }}$ & Allowable shear force of a pile or rigid inclusion at SLS, according to concrete strength & {$[\mathrm{m} / \mathrm{s}]$} \\
\hline $\mathrm{V}_{\mathrm{s}}$ & Shear wave velocity (called secondary) & {$[\mathrm{m}]$} \\
\hline $\mathrm{w}_{\mathrm{c}}$ & Spherical settlement & {$[\mathrm{m}]$} \\
\hline$w_{d}$ & Deviatoric settlement & {$[\mathrm{m}]$} \\
\hline W & Total settlement under central load & {$[\mathrm{m}]$} \\
\hline W & Water content & {$[-]$} \\
\hline$w r(z)$ & Relative settlement & {$[\mathrm{m}]$} \\
\hline $\mathrm{w}_{\mathrm{s}}(0)$ & Footing downward displacement & {$[\mathrm{m}]$} \\
\hline $\mathrm{Y}^{\prime}$ & Inclusion or footing rotation & rd \\
\hline $\mathrm{y}_{\max }$ & Maximum footing downward displacement & {$[\mathrm{m}]$} \\
\hline (z) & Depth, variable of functions $w(z), t(z)$ & [m] \\
\hline $\mathrm{z}$ & Lever arm & {$[\mathrm{m}]$} \\
\hline
\end{tabular}

\section{Greek notations}

\begin{tabular}{|c|c|c|}
\hline$\alpha$ & Structural coefficient (Fascicle 62, Ménard, $=\mathrm{E}_{\mathrm{M}} / \mathrm{E}$ ) & {$[-]$} \\
\hline$\alpha$ & Hoop incline & \\
\hline$\alpha_{\mathrm{cw}}$ & EC2 coefficient & \\
\hline$\alpha_{1}$ & $=\mathrm{E}_{\text {oed }} / \mathrm{q}_{\mathrm{c}^{\prime}}$ & {$[-]$} \\
\hline$\alpha_{2}$ & $=\sigma_{\text {max }} / \sigma_{\text {moy }}$ & {$[-]$} \\
\hline$\alpha_{i}$ & Between 0 and 1.5 & \\
\hline$\alpha$ & $\begin{array}{l}\text { Cover ratio of soil reinforced with rigid inclusions, equal to ratio of area covered by inclusion heads } \\
\text { to total surface area treated }\end{array}$ & \\
\hline$\alpha_{c c}$ & Coefficient depends on whether or not reinforcements are present & \\
\hline$\alpha_{\mathrm{cpl}}$ & EC2 coefficient dependent on whether or not reinforcements are present & \\
\hline$\beta$ & $\begin{array}{l}\text { Incorporation ratio for stone column reinforcements, equal to ratio of area covered by inclusion heads } \\
\text { to total surface area treated }=A_{\text {col }} / S_{\text {mesh }}\end{array}$ & {$[-]$} \\
\hline$\beta$ & Reduction coefficient applied to rotational stiffness, according to percentage compressed surface area & {$[-]$} \\
\hline$\beta_{1}$ & $\begin{array}{l}\text { Reduction coefficient applied to rotational stiffness, according to percentage compressed surface area } \\
\mathrm{K}_{\varphi} / \mathrm{K}_{\varphi \mathrm{NS}}\end{array}$ & {$[-]$} \\
\hline$\delta$ & Friction angle between footing and soil & [rad] \\
\hline
\end{tabular}




\begin{tabular}{|c|c|c|}
\hline$\varepsilon$ & Deformation per unit length $(\Delta \mathrm{l} / \mathrm{l}, \Delta \mathrm{l}$ displacement towards component 1$)$ & $\%$ \\
\hline$\varnothing$ & Equivalent diameter of foundation slab & {$[\mathrm{m}]$} \\
\hline$\emptyset_{1}$ & Diameter of inclusion, pile or stone column & {$[\mathrm{m}]$} \\
\hline$\varnothing_{2}$ & Diameter of circle where the most eccentric inclusions are located & {$[\mathrm{m}]$} \\
\hline$\Phi$ & Rotation angle of wind turbine around a horizontal axis & [rad] \\
\hline$\varphi^{\prime}$ & Effective friction angle & {$\left[{ }^{\circ}\right]$} \\
\hline$\varphi_{\mathrm{c}}$ & Stone column friction angle & {$\left[{ }^{\circ}\right]$} \\
\hline$\varphi_{\text {eq }}$ & Equivalent friction angle & {$\left[{ }^{\circ}\right]$} \\
\hline$\varphi_{\mathrm{R}}^{\prime}$ & Residual friction angle & {$\left[{ }^{\circ}\right]$} \\
\hline$\varphi_{\mathrm{s}}$ & Soil friction angle & {$\left[{ }^{\circ}\right]$} \\
\hline$\gamma$ & $\begin{array}{l}\text { Angular distortion or deformation ( } 2 \Delta \alpha \text { or } 2 \mathrm{~d} t / \mathrm{l}, \mathrm{dt}=\text { perpendicular displacement) } \\
\text { (not to be confused with safety factors) }\end{array}$ & $\%$ \\
\hline$\gamma_{b}$ & Safety factor on inclusion tip & {$[-]$} \\
\hline$\gamma_{\mathrm{c}}$ & Partial factor on inclusion material & \\
\hline $\begin{array}{l}\gamma_{\text {load-transfer platform }} \\
\text { or } \gamma_{\text {plat }}\end{array}$ & Safety factor on load transfer platform at punching & {$[-]$} \\
\hline$\gamma_{s}$ & Safety factor on inclusion friction & {$[-]$} \\
\hline$\gamma_{\mathrm{sf}}$ & Safety factor on footing/soil friction & {$[-]$} \\
\hline$\gamma_{\text {soil }}$ & Safety factor on soil bearing under footing & {$[-]$} \\
\hline$\gamma_{\varphi}$ & Safety factor on friction angle & \\
\hline v & Poisson's ratio & {$[-]$} \\
\hline$v_{\mathrm{Eq}}$ & Equivalent Poisson's ratio for soil reinforced with stone columns or rigid inclusions & {$[-]$} \\
\hline$\sigma_{\text {clim }}$ & Ultimate design compressive strength & {$[\mathrm{Pa}]$} \\
\hline$\sigma_{\text {col }}$ & Vertical compressive strength in stone column & {$[\mathrm{Pa}]$} \\
\hline$\sigma_{\mathrm{cp}}$ & Mean compressive stress in inclusion & {$[\mathrm{Pa}]$} \\
\hline$\sigma_{\mathrm{i}}$ & Compressive stress in imaginary column surmounting inclusion or column & {$[\mathrm{Pa}]$} \\
\hline$\sigma_{\text {plat }}^{\prime}$ & Punching strength & {$[\mathrm{Pa}]$} \\
\hline$\sigma_{\max }$ & Maximum soil stress under footing & {$[\mathrm{Pa}]$} \\
\hline$\sigma_{\min }$ & Minimum soil stress under footing & {$[\mathrm{Pa}]$} \\
\hline$\sigma_{\text {moy }}$ & $\mathrm{Fz} / \mathrm{S}_{\mathrm{sem}}$ & {$[\mathrm{Pa}]$} \\
\hline$\sigma_{\mathrm{s}}$ & Vertical compressive stress outside of inclusion or column & {$[\mathrm{Pa}]$} \\
\hline$\theta$ & Diffusion angle of rods & {$[\mathrm{Pa}]$} \\
\hline$\tau_{\mathrm{cp}}$ & Shear stress & {$[\mathrm{Pa}]$} \\
\hline$\tau_{\mathrm{RI}}$ & Shear stress in imaginary column above inclusion or column & {$[\mathrm{Pa}]$} \\
\hline$\tau_{\mathrm{s}}$ & Shear stress outside of inclusion or column & {$[\mathrm{Pa}]$} \\
\hline
\end{tabular}




\section{Acronyms}

Acc

AGAP

ANR

ASIRI

CBR

$\mathrm{CCH}$

DLC

DTU

F

DR

ERP

LT

MASW

NS

OPM

PLU

PPR

PSV

[Q]

QP

$\mathrm{R}$

[R]

RI

SLS

SC

SOLCYP

ST

ULS

ZIG
Accidental

Assurance qualité des prestations de services en Géophysique APpliquées (French standards for best practices in applied geophysics)

French National Research Agency (in French: Agence nationale de la recherche)

Amélioration des Sols par Inclusions Rigides (French national project for soil improvement using rigid inclusions, www.irex-asiri.fr)

Californian Bearing Ratio

Code de la Construction et de l'Habitation (French construction and housing code)

Design Load Case (Standard NF EN 61-400)

Document technique unifié (technical unified document)

Fundamental

Request for Information (in French: Demande de Renseignements)

Public Access Building (in French: Etablissement recevant du public)

Long-term

Multichannel Analysis of Surface Wave

Not heaved (in French: Non soulevé)

Optimum Modified Proctor

Local Urban Development Plan (in French: Plan local d'urbanisme)

Risk Prevention Plan (in French: Plan de prévention des risques)

Vertical Seismic Profile (in French: Profil sismique vertical)

Survey/test providing qualitative information to complement other tests (see USG Recommendations sur les investigations minimales)

Quasi permanent

Rare

Survey/particularly well-adapted survey (see USG Recommendations sur les investigations minimales) to plan in priority.

Rigid inclusion

Serviceability limit state

Stone column (in French: CB, Colonne Ballastée)

SOLlicitations CYcliques des Pieux (French national and ANR research project) www.pnsolcyp. org

Short-term

Ultimate limit state

Geotechnical zone of influence (in French: Zone d'influence géotechnique) 


\section{Background}

In accordance with the national foreword to the Eurocode 7 Recommendations, Part 1 and $\S$ A.P.1 (1), readers are reminded that during "the transition period required for all of these European standards... members of the CEN (European Committee for Standardization) are permitted to maintain their own previously adopted national standards".

In addition, Eurocode 7 (Standard NF EN 1997-1, 2005, Part 2 on "The Bases for Geotechnical Calculation" $\S 2.1$ (21) specifies that wind turbines belong to the category of "very large and unusual structures" and therefore fall within Geotechnical Category 3, "which should usually be subject to rules and procedures other than those found in this standard." These recommendations apply to the design and inspection of wind turbine foundations and can be included among "other" alternative rules and procedures.

The initiatives taken regarding the design, calculation, installation and inspection of wind turbine foundations are based on current regulations, and on additional procedures included in this document that take account of the specific features of this type of structure.

These recommendations will be updated according to feedback based on experience, in view of expected advances in: knowledge of real soil stresses (via windturbineinstrumentation), behavior of foundations under cyclic loads (progress made by the SOLCYP project on the behavior of piles subject to cyclic loads), application of Eurocode standards, and the ASIRI research project on soil improvement using rigid inclusions.

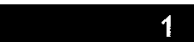

\section{Introduction}

\section{1.}

\section{Wind turbine types and definitions}

Wind turbines are devices that convert kinetic energy from the wind into mechanical energy. They are usually categorized mainly according to their height, location, and their rotor diameter, which is linked to how much power they produce.

\section{1.}

\section{Mainly on-shore wind turbines higher than 12 meters}

These recommendations concern on-shore horizontal-axis wind turbines (HAWT) pointed either upwind (with their rotor blades on one side of the tower pointed forward into the wind) or downwind. They apply to wind turbines used for industrial purposes, on which the rotor's axis of rotation is located more than 12 meters above the platform. Use of these recommendations is not justified for verifying domestic wind turbines less than 12 meters high.

The terms "wind turbine" (the preferred term), "aerogenerator" and "wind mill" all designate a machine with the following components:

\section{W.}

\section{Rotor}

The rotor is composed of a set of turbine blades and a low-speed rotor shaft. The rotor is the component that directly receives wind energy, and is connected to the high-speed shaft in the nacelle by the rotor hub.

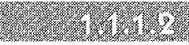

\section{Nacelle}

The nacelle is located at the top of the wind turbine and houses the components generating electrical energy, as well as other components (generator, gearbox, brake, coolers, etc.).

\section{1.}

\section{Tower or main shaft}

The tower is part of the turbine that supports the nacelle and the rotor. It is built sufficiently high to enjoy the best wind conditions and ensure free movement of the blades. Towers may be guyed, supported by a lattice (for small wind turbines), or cylindrical. This document relates to non-guyed cylindrical towers only. The support system designates both the tower and the foundation.

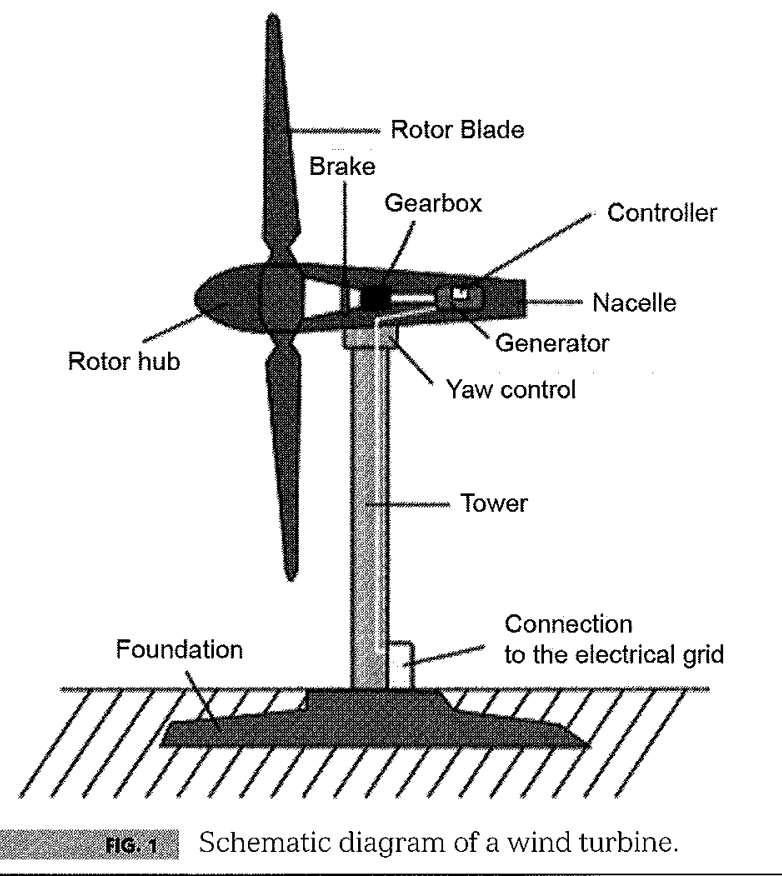

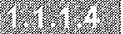

\section{Foundation system}

The foundation system includes the upper part of the base, which links the tower to the foundation elements transferring loads to the soil. In this document, the foundation types discussed include:

- Shallow foundations (gravity-base), see § 5.2;

- Shallow foundations on soil reinforced with stone columns, see $\S 5.3$;

- Shallow foundations on soil reinforced with rigid inclusions, see $§ 5.4$;

- Deep pile foundations, see $\$ 5.5$;

- "Hybrid" or "composite" foundations, see $\$ 5.6$. 
$-1 m$

Gravity base

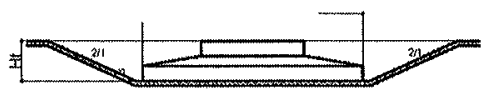

$-3$

On rigid inclusions

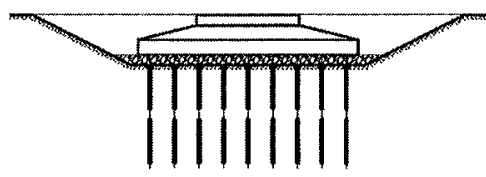

$-5-$

On hybrid foundations

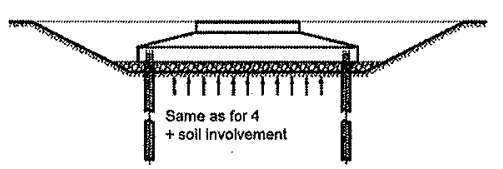

$-2-$

On stone columns

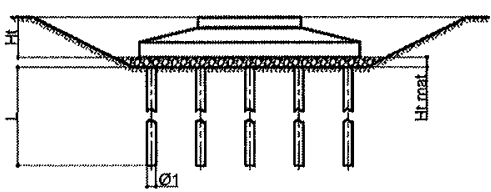

$-4 \cdot$

On piles

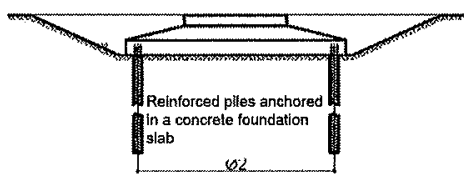

$-6-$

On composite foundations

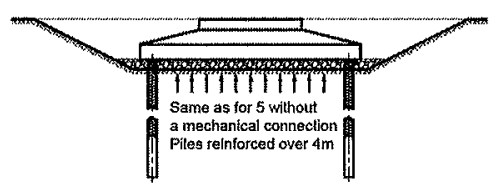

\section{1.}

\section{Off-shore wind turbines}

Special studies must be carried out for off-shore wind turbines, to take into account the specific forces that act on the structure (swell waves, ship impacts, ice, etc.) and geotechnical conditions specific to the marine environment. Such studies are not addressed in these reccomendations.

\section{0.}

\section{Wind turbines shorter than 12 meters}

The recommendations in this document are not intended for wind turbines shorter than 12 meters. In France, this type of wind turbine is not subject to the same urban development code, even though it is still necessary to obtain a construction permit and respect certain procedures and current laws.

In most cases, these wind turbines are for home use and, given their dimensions, they are considered more akin to appliances such as lamps, candelabras, signs, etc.

\section{(1)}

\section{Folding guyed wind turbines}

The purpose of folding guyed wind turbines is to limit structural damage during tropical storms, hurricanes or tornados. They are found most often in areas most affected by this kind of climatic phenomena (such as the West Indies, Réunion, etc.) and must be subject to special studies.

\section{thts}

Wind farms, wind turbine fields and groups

The term "wind farm" (also referred to as a wind turbine "park", "field" or "wind power plant") refers to a group or several groups of wind turbines concentrated in a limited geographic area with the same contractor and electricity provider. In this document, "wind farm" is used to refer to wind turbine farms, parks and fields in a given area. In contrast, the term "wind turbine group" will be used to refer to a set of wind turbines built in an area that is homogenous from a geotechnical and geological perspective (soil type, stratigraphy, mechanical properties, etc.).

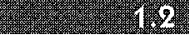

\section{Field of application for these recommendations}

This document concerns on-shore wind turbines over 12 meters high only, either average size (with a rotor diameter of between 12 and 60 meters), or "giant" (with a rotor diameter greater than 60 meters). The recommendations do not apply directly to:

- Off-shore wind turbines;

- Guyed wind turbines.

For wind turbines located in earthquake-prone areas, studies must be carried out to take this risk into account. This document does not address this issue. 


\section{Definitions of general relevance}

\section{6.}

\section{Site Data}

Site data includes environmental information and data on seismic risks (not addressed in this document), the soil, and the electrical network for a given wind turbine site. The wind data should be statistics based on 10-minute samples, unless specified otherwise.

\section{Thes}

\section{Environmental Conditions}

Environmental conditions are factors such as wind, altitude, temperature, and humidity that can affect the behavior of a wind turbine.

\section{1.}

\section{External Conditions}

These factors include all those that affect the working of a wind turbine, including environmental conditions (temperature, snow, ice, etc.), and also the state of the electrical network. Wind conditions are the main external factor that must be taken into account for structural integrity. Soil properties are particularly important for wind turbine foundation design.

\section{3.}

\section{Environmental Constraints}

For the purpose of these recommendations, environmental constraints are those identified by French law regarding preventative measures against natural disasters (referred to as PPR and appended to the Plans Locaux d'Urbanisme, or PLU) as defined by the French Environmental Code (Article L562-1). The purpose of these measures is to reduce the vulnerability of individuals and property. The risks to be assessed include flooding, earthquakes (not addressed in this document), ground movement, forest fires, and avalanches, etc.

\section{References}

See Appendix F for a complete list of sources and standards cited in this document.

\section{1}

\section{Regulatory framework}

Since October 1, 2008, Article R111-38* of the French Construction and Housing Code now includes a sixth point concerning the technical inspection of wind turbines whose tower and nacelle are more than 12 meters above the soil. These structures are covered by French Law 78-12 (January 4, 1978) dealing with legal responsibility and insurance for construction and building. This law known as the "Spinetta Law" was amended by Law 2008-735 (July 28, 2008) and applies to the whole of France and its territories.

Comment: As specified by Article L111-23 of the Construction and Housing Code, which identifies structures legally subject to technical inspection.

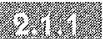

\section{Principles of the Spinetta Law}

France's Spinetta Law includes three sections whose main principles are the following.

\section{3 ).}

Title I: All contractors are subject to decennial liability for their works

The term "contractor" may designate:

- Architects, entrepreneurs, technicians, or other individuals bound to the contracting authority through a labor or service contract (locatio operis);

- Any individual bound to the contracting authority through a labor or service contract (locatio operis);

- Any individual who sells a completed structure which s/he has built or has had built;

- Any individual who, although acting as an agent for the building owner, performs similar duties to a contractor.

\section{1.}

\section{Title II: Building construction} technical inspection

At the contractor's request, a technical supervisor provides opinions on technical problems or issues as part of a binding legal agreement with the contractor.

In particular, these opinions relate to structural stability and human safety.

At each stage of the construction process, the technical supervisor critically inspects the documents submitted to him or her and ensures that technical verifications under the builders' responsibility are carried out satisfactorily. Technical inspection is a legal requirement for certain types of constructions specified in Article R111-38 of the French Construction and Housing Code and Article 2 of Decree 2007-1327 (September 11, 2007), which includes wind turbines "whose tower and nacelle are more than 12 meters above the soil".

\section{2)}

\section{Title III \& Title IV: Mandatory insurance for construction works}

All natural persons and legal entities subject to decennial liability according to Article 1792 and subsequent articles of the French Civil Code must be insured. Any natural person or legal entity that has "construction works" carried out in its capacity as a construction owner must take out insurance guaranteeing coverage for all reparation work to any damage, excluding efforts to seek liability, before the start of construction works. 


\section{Reference standards}

\section{8}

\section{Standard NF EN 61400-1 (June 2006)}

European Standard NF EN 61400-1: 2005 (Wind Turbines: Design Requirements) specifies design requirements for wind turbines, especially those associated with load cases. It is not intended to give requirements for wind turbines installed offshore, in particular for the support structure (the components of a wind turbine including the tower and foundation as defined in $\$ 3.49$ of this standard).

Wind turbine foundation design should enable the structure to:

- Withstand vertical, horizontal, static and transient stresses resulting from the wind turbine itself, its operation, wind conditions, and from potential earthquakes (not addressed in this document);

- Have total and differential settlement compatible with the wind turbine's safe operation.

The expected life span at design for Class I, II and III wind turbines (in normal onshore wind conditions) must be at least 20 years ( $\$ 6.2$ NF EN 61400-1). They are subject to a European "Machinery" directive and $\mathrm{CE}$ marking. The concept of machinery is very wide and covers wind turbine towers.

\section{5 .}

\section{Standard NF P 94-500 (December 2006)}

Wind-turbine foundation design requires appropriate geotechnical studies, namely knowledge of loads, and correct estimates of stresses and settlement, which must be calculated in geotechnical engineering studies as detailed in the French Standard NF P 94-500. Geotechnical studies must also be conducted to assess soil properties for a given site with reference to locally available construction standards and regulations.

\section{5.}

\section{Standards for foundation calculations}

The foundations typically used are either shallow or deep. Soil improvement or reinforcement procedures are also usually carried out. Calculation recommendations for foundations depend on whether they are shallow or deep. In France, the current reference documents ${ }^{(1)}$ are:

- Fascicle 62, Title V (MELT, 1993);

- Specific approved specifications;

- "Recommendations for the design, calculation, construction and supervision of stone columns under buildings and structures subject to settlement" by the Comité Français de Mécanique des Sols (CFMS, the French committee for soil mechanics), 2011 and referred to in this document as the "CFMS Stone-Column Recommendations";

- A technical information note by 0 . Combarieu: "Calcul d'une fondation mixte semelle-pieux sous charge verticale centrée" (calculation of a hybrid footing-pile foundation under a central vertical load).

(1) Pending publication of Eurocode 7 (NF EN 1997-1 \& NF EN 1997-1/ NA) on geotechnical calculations.
Comment: the national implementation standard of Eurocode 0 (NF EN 1990-1/NA) suggests a classification into project-duration categories (10, 25,50 , or 100 years) and geotechnical categories, resulting in three basic justification families:

- Qualitative geotechnical surveys and experiments;

- Geotechnical surveys and calculations;

- Geotechnical surveys and in-depth calculations.

Wind-turbine foundations usually fall within the third category.

\subsection{5.}

\section{Standard NF P 03100 (September 1995)}

Technical inspection of construction in France is carried out in accordance with National Standard NF P 03100 specifying the "General technical supervision requirements for preventing technical risks during construction". The concept of technical inspection implies the existence of both an object to inspect and a reference document to which it can be compared. The reference document includes the technical procedures that are to be supervised and that are found in construction industry documents. They include:

- French National Standards;

- Documents Techniques Unifiés (DTU), which are documents specific to the French building and construction industry issued by the Commission Générale de Normalisation du Bâtiment (the French commission for construction standards);

- Professional recommendations and regulations.

3

\section{Load cases and design loads}

\subsection{1. \\ Introduction}

The basic load cases are provided by the builder and are based on certain conceptual situations described in National Standard NF EN 61400 (electricity generation, electricity generation and unexpected breakdowns or malfunctions, etc.). These various load cases are calculated according to a turbine's expected life span (pm: 20 years, or about 175,000 hours).

\section{2}

\section{Load case analysis}

The reference documents to be taken into consideration are:

- French Standard NF EN 61-400;

- Any additional special builders' specifications.

The various load cases must be communicated in non-weighted values.

\section{3}

\section{Determining usable load cases for foundations}

Table 2, Article 7.4, Standard NF EN 61-400 (pages 34-35) lists 22 load cases, which sometimes include the weight of the foundation slab. 
Comment: Other load cases must also be taken into account if they are related to structural integrity for the design of particular types of wind turbines (guyed, folding, etc.), but are not included in these recommendations.

For each of these loads, the weighted values should be defined to determine the loads at Ultimate Limit State (ULS) and Serviceability Limit State (SLS).

\section{4}

\section{Design loads at SLS and ULS}

\section{(4)}

\section{Determining load cases for foundations}

These load cases must be classified according to standard design loads:

- Quasi-permanent (QP) SLS and Rare (R) SLS;

- Fundamental (F) ULS and Accidental (ACC) ULS.

The following Design Load Cases (DLC) are to be taken into account when designing the foundations:

- Theoretical situation 1 (electricity production);

- Load cases 1.1, 1.3, 1.4 and 1.5 $\quad$ DLC $_{\text {Rare }}$

- Load case 1.2

Fatigue

- Theoretical situation 2 (electricity production + breakdown);

- Load cases 2.1, 2.2 and 2.3 $\quad$ DLC $_{\text {Rare }}$

- Load case 2.4

- Theoretical situation 5 (emergency stop)

- Load case 5.1 Fatigue

DLC $_{\text {Bare }}$

- Theoretical situation 6 (shut-down [complete stop or slow-down]);

- Load cases 6.1 and 6.3

- Load case 6.2

- Load case 6.4

DLC $_{\text {Rare }}$

${ }_{\text {DLC }}^{\text {Rare }}$

Fatigue

- Theoretical situation 7 (shut-down and malfunction conditions);

- Load case 7.1
Comments: At this stage, pending the conclusions of the French national research project SOLCYP, the "fatigue" load cases are not to be taken into account for foundation system design in relation to the soil. They are used to verify the structure and the reinforced concrete foundation slab.

Builders sometimes add a "DLC 1.0" load case, which is regarded as a $D L C_{Q P}$

Builders must give the least favorable case for each $\mathrm{DLC}_{\mathrm{qp}^{\prime}}, \mathrm{DLC}_{\text {Rare }}, \mathrm{DLC}_{\mathrm{Acc}}$ and "fatigue" load case.

\section{1.}

\section{Weighting factors}

Except for situations of fatigue, the weighting factors listed in Table 1 must be applied to define the design loads at SLS and ULS.

Comment: Remember that the torque affecting the foundation base is composed of $F_{2}$ vertical compressive force, Hhorizontal stress and M overturning moment. This torque should take into account the presence or absence of water. The resulting water pressure is taken into account if the ground water level is higher than the bottom surface of the foundation slab.

Comment: The partial safety factor generating the least favorable design situation should be taken into account.

\section{5}

\section{Verifying Design Requirements}

\section{5.}

\section{Percentage of compressed surface area under shallow foundations}

This concerns footings that are usually circular and considered to be infinitely rigid. The percentage of compressed surface area $\left(\mathrm{S}_{\text {comp }} / \mathrm{S}_{\text {sem }}\right)$ must be at least those indicated in Table 2 below.

\begin{tabular}{|c|c|c|c|c|c|}
\hline & & & ate & rits & riterer \\
\hline \multirow{2}{*}{$\mathrm{DLC}_{\mathrm{QP}}$} & ULS $_{\text {Fond }}$ & 1.0 or 1.35 & 1.8 & 1.8 & $1.125 \times 1.05$ \\
\hline & SLS $_{\text {perm }}$ & 1.0 & 1.0 & 1.0 & 1.0 \\
\hline \multirow{2}{*}{$\mathrm{DLC}_{\text {Rare }}$} & ULS $_{\text {Fond }}$ & 1.0 or 1.35 & 1.5 & 1.5 & $1.125 \times 1.05$ \\
\hline & SLS $_{\text {Rare }}$ & 1.0 & 1.0 & 1.0 & 1.0 \\
\hline $\mathrm{DLC}_{\mathrm{Acc}}$ & ULS $_{\text {Acc }}$ & 0.9 or 1.1 & 1.1 & 1.1 & 1.0 \\
\hline
\end{tabular}

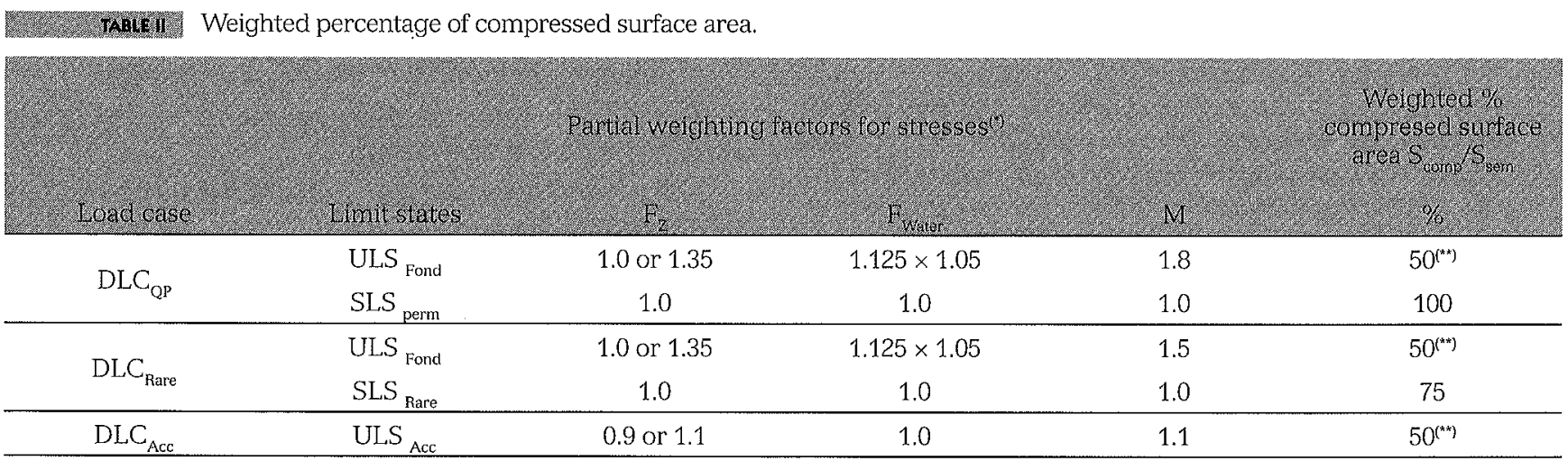




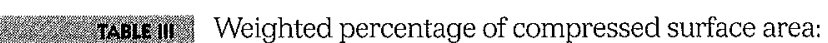
additional information for stiff soil.

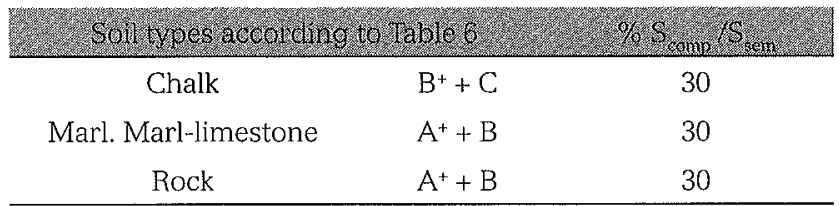

\section{0}

\section{Bearing capacity requirements}

The soil design stresses enable the foundations to be justified at the Serviceability and Ultimate Limit States (SLS and ULS).

- The design loads at the ULS calculated for DLC ${ }_{\text {Op }}$, $\mathrm{DLC}_{\text {Rare }}$ and $\mathrm{DLC}_{\mathrm{Acc}}$ load cases (weighted) enable the $\mathrm{q}_{\text {refts }}$ design stress to be determined (fundamental ULS, as per Fascicle 62 Title V by MELT, 1993).

- The design loads at the SLS calculated for DLC $\mathrm{OP}_{\mathrm{QP}}$ and $D L C_{\text {Rare }}$ (not weighted) enable the $\mathrm{q}_{\text {refSLS }}$ design stress to be determined (SLS is respectively quasi permanent and rare, as per Fascicle 62 Title V by MELT, 1993).

These values are to be compared to the ultimate soil resistance values established as part of a geotechnical study.

The important role of "percentage of compressed surface area" should be emphasized. As shown by Figure 3 for circular footings, when this parameter is at $30 \%$ it can increase the maximum stress by 8 times the stress obtained under the same hypothetical central vertical load.

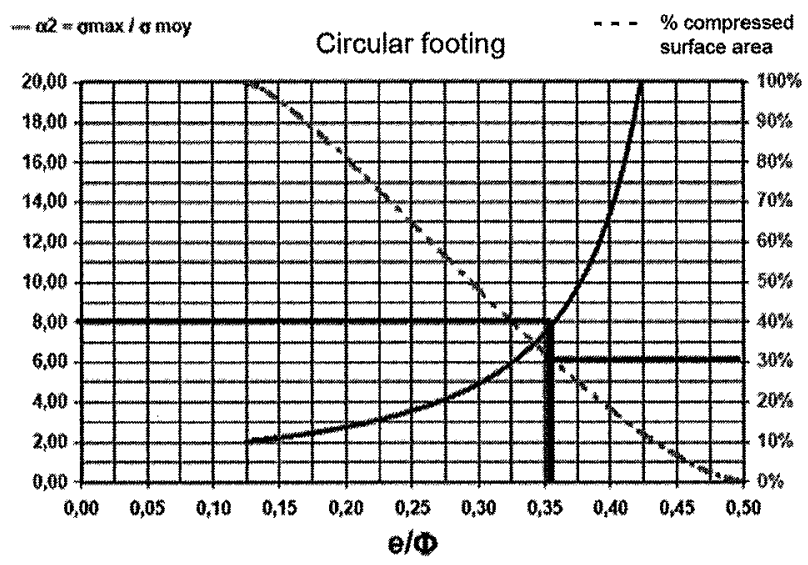

16. 3 Correlation between eccentricity, \% of compressed surface area $S_{\text {comp }} / S_{\text {sem }}$ and maximum stress.

Comment: The "compressed surface area $S$ " used later and suggested in Figure 3 is the value obtained by ignoring heaved sections. $S_{\text {ref }}$ is the "imaginary compressed surface area" value used in overall bearing verifications. These two surface areas are defined in Appendix B.

In accordance with current recommendations, the reference design stress must be verified in relation to the allowable stress at SLS and ULS. Depending on the minimum and maximum bearing stresses $\sigma_{\min }$ and $\sigma_{\max }$ under the footing, this reference stress value $\mathrm{q}_{\text {ref }}$ equals:

$$
q_{\text {ref }}=\left(3 \cdot \sigma_{\text {max }}+\sigma_{\text {min }}\right) / 4 \text { with } \sigma_{\text {min }} \geq 0
$$

This stress reference value can also be calculated for a rectangular surface by following the Meyerhof approach. For a circular surface, the "half-moon" model (see Appendix B) is followed.

\section{6.}

\section{General model}

The reference stress value can be calculated as follows:

$$
\begin{aligned}
\sigma_{\text {avg }} & =F_{z U L S} / S_{\text {sem }} \\
\alpha_{2} & =\sigma_{\text {max }} / \sigma_{\text {avg }}
\end{aligned}
$$

(see solid-line curve on Figure 3)

$$
\begin{gathered}
\mathrm{e}=\mathrm{M}_{\mathrm{ULS}} / \mathrm{F}_{\mathrm{zULS}} \\
\mathrm{q}_{\mathrm{ref}}=3 \cdot \alpha_{2} \cdot \sigma_{\mathrm{avg}} / 4 \text { if } \sigma_{\text {min }}=0
\end{gathered}
$$

Example from Figure 3: e/ $\Phi=0.35>1 / 8$

$\%$ compressed surface area: $30 \% \mathrm{~S}_{\text {ref }}$

$$
\begin{gathered}
\alpha_{2}=\sigma_{\max } / \sigma_{\text {avg }}=8 \text {, and } \sigma_{\min }=0 \\
\mathrm{q}_{\mathrm{ref}}=3 \cdot \alpha_{2} \cdot \sigma_{\mathrm{avg}} / 4=6 \sigma_{\mathrm{avg}}
\end{gathered}
$$

\section{5is 3}

\section{The "Half-moon" model for a circular surface}

The reference stress value can also be calculated by using what is referred to as the "half-moon" method, which is defined in Appendix B.

The reference surface area value $S_{\text {ref }}$ is the hatched zone on the figure in Appendix B (half-moon: bound by two symmetrical circular arcs in relation to an axis measured at $\mathrm{e}=\mathrm{M}_{\mathrm{ULS}} / \mathrm{F}_{\mathrm{zULS}}$ from the center of the wind turbine)

$$
\mathrm{q}_{\mathrm{ref}}=\mathrm{F}_{\mathrm{zuLS}} / \mathrm{S}_{\mathrm{ref}}
$$

Comment: For a circular foundation, the two $q_{\text {ref }}$ calculations give very similar results.

It is advisable to verify that the chosen foundation system is compatible with the maximum stress.

\section{(6)}

\section{Sliding failure}

The following must be verified at ULS:

$$
\mathrm{H}_{\mathrm{ULS}}<\mathrm{F}_{z \mathrm{~min}} \cdot \tan \delta / \gamma_{\mathrm{S}^{\prime}}
$$

Comment: $\delta$ is the friction angle between the footing and soil, and is considered to be the soil friction angle $\varphi^{\prime}$, $\gamma_{s}$ is a safety factor equivalent to 1.2 under fundamental load combinations, 1.1 under accidental combinations and $F_{z m i n}$ is the minimum compression transmitted to the soll by the footing. For foundation components poured in-situ, the material's critical state angle must be used. The standard for retaining structures also notes that $\varphi^{\prime}$ is often greater than $\varphi_{\text {critical }}^{\prime}$ For prefabricated components, this is $2 / 3$ of the critical state angle.

The $\varphi^{\prime}$ value to be taken into account is established as part of a geotechnical study.

Soil passive pressure and soil cohesion are generally not taken into account.

Comment: The horizontal stresses in the footing underside therefore equals the stresses applied in footing head. Nevertheless, when the concrete foundation slab is poured directly in the excavation, the footing passive pressure can be taken into account up to a value determined by the geotechnical study, although this is to be limited to $30 \%$ of the maximum passive pressure value. 


\section{Long-term (LT) rotation requirement}

The builder usually provides an ultimate value for rotation requirement (in $\mathrm{mm} / \mathrm{m}$ ) at SLS, which must not be exceeded during the structure's life span. It takes into account the permanent deformations due to normal wind conditions (it can be calculated using values obtained by combining the $\mathrm{DLC}_{\mathrm{OP}}$ with "longterm" characteristics), but also due to "short-term" effects from stronger wind forces caused by DLC $\mathrm{C}_{\text {rare }}$ or $\mathrm{DLC}_{\mathrm{Acc}}$ design load cases (calculated on the basis of "short-term" characteristics).

The rotation moment ratio $\mathrm{M}_{\mathrm{xy}}$ applied to the foundation for a rotation value $\varphi$ is designated by a rotational stiffness ratio (expressed in $\mathrm{MN} / \mathrm{rad}$ or a multiple).

$\mathrm{K}_{\varphi}$ (in $\mathrm{MNm} / \mathrm{rad}$ ) with

$$
\varphi=M_{x y} / K_{\varphi}
$$

$\mathrm{K}_{\mathrm{oLT}}$ "long-term" rotational stiffness ratio assessed for DLC ${ }_{\mathrm{QP}}$ :

- calculated using standard soil-mechanics formulae (laboratory, pressuremeter and penetrometer tests);

$\mathrm{K}_{\phi C T}$ "short-term" unweighted rotational stiffness

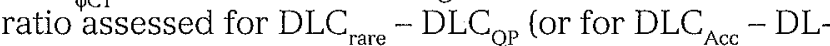
$\mathrm{C}_{\mathrm{QP}}$, in accordance with the builder's specifications):

- calculated using geodynamic and shear modulus G formulae (see $\$ 4.6 .3 .2$ );

- calculated using numerical analysis models, or failing this, calculated using LT soil mechanics values for deformations of about $10^{-2}$ and multiplying this value by 2 .

\section{3...}

\section{Rotational stiffness requirements $\mathrm{K}_{\varphi}$ dyn}

\section{3.61}

\section{Rotational stiffness}

Builders require a minimum rotational stiffness value for small deformations of " $\mathrm{K}_{\text {pdyn }}$ " (from $10^{-5}$ to $10^{-3}$ ) to avoid coupling phenomena with the machine's mechanical components.

This value is to be taken into account under all of the machine's operational conditions.

$\mathrm{DLC}_{\mathrm{QP}}$ and some $\mathrm{DLC}_{\mathrm{Rare}}$ values, in accordance with the builders' specifications (for conceptual situations 1 \& 2 described in Standard NF EN 61 400).

The rotational stiffness calculations require the following information for a foundation slab:

- Its dimensions (diameter, area, etc.);

- The percentage compressed surface area;

- And for each soil layer, the variation curves for the elasticity modulus $E$ and shear modulus $G$, according to the distortion $\gamma$, and Poisson's ratio $v$.

Provided that the soil remains completely compressed under the whole foundation slab, and if we remain within the elastic area, it is possible to use the stiffness ratios $K_{p N S}$ (see Table 7) on the basis of a shear modulus $\mathrm{G}$ measured in the appropriate deformation range.
Comment: When the soil is not entirely compressed, a reduction coefficient $\beta_{\mathrm{i}}=K_{\varphi} / K_{\varphi N S}$ can be applied to the rotational stiffness according to the percentage compressed surface area $\left(S_{\text {comp }} / S_{\text {sem }}\right) . \beta_{1}$ is calculated by comparison with the material's strength, with an implicit solution through successive iterations.

Initially, the values for $\beta$ are depicted by the relationship $M_{x y} / F_{z}\left(M_{x y}\right.$ and $F_{z}^{\prime}$ both unweighted) and the foundation diameter $\Phi=2 \mathrm{r}$ in the following graph.

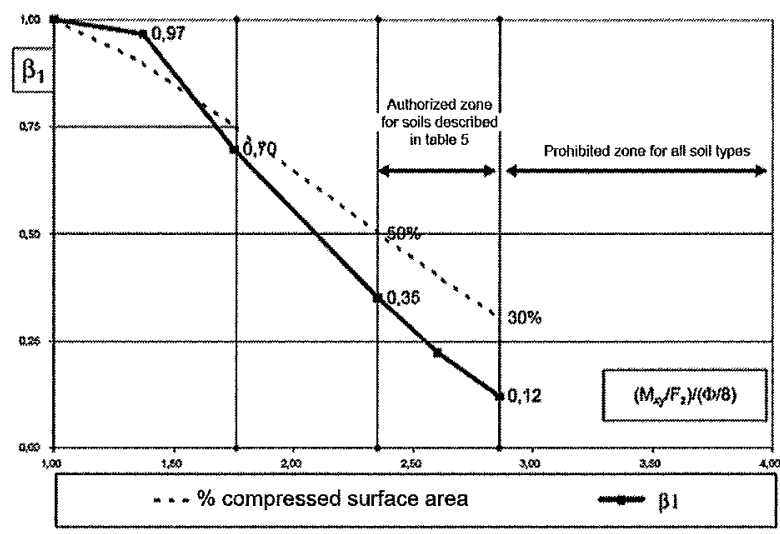

Reduction coefficient $\beta \mathbf{i}$ values applied to rotational stiffness.

Example:

$$
\begin{gathered}
\left(\mathrm{M}_{\mathrm{xy}} / \mathrm{F}_{\mathrm{z}}\right) /(\operatorname{diam} / 8)=2.3 \\
\% \text { compressed }=50 \% \\
\text { and } \beta_{1}=0.35, \mathrm{~K}_{\varphi}=0.35 \mathrm{~K}_{\varphi \mathrm{NS}}
\end{gathered}
$$

\section{3 is}

\section{"Static" and "dynamic" stiffness}

For distortions $\gamma$ of about $10^{-2}$ to $10^{-3}$, the rotational stiffness is usually called "static".

For distortions $\gamma$ of about $10^{-6}$ à $10^{-4}$, the rotational stiffness is usually called "dynamic". In these recommendations, "static" rotational stiffness is to be used to verify settlement and deformation; "dynamic" rotational stiffness enables the absence of coupling phenomena between the soil, foundations and the machine to be guaranteed.

\section{6.}

\section{Stiffness requirements in displacement}

These criteria are sometimes set by the builder and are linked to the horizontal stiffness $\left(\mathrm{K}_{\mathrm{x}^{\prime}} \mathrm{K}_{\mathrm{y}}\right)$ and vertical stiffness $\mathrm{K}_{\mathrm{z}}$.

Comment: The vertical or horizontal stiffness ratio (expressed in $\mathrm{N} / \mathrm{m}$ or a multiple) is designated by the ratio of vertical force $F_{z}$ or horizontal force $H$ applied to the foundation during its vertical or horizontal displacement $w$.

The stiffness values calculated must be greater than those laid down by the builder. 


\section{Geotechnics and design parameters} 4.1.

\section{Introduction}

As a reminder, the sequence of geotechnical engineering operations is defined by the NF P94-500 standard. In particular, this standard includes the following at the "studies" stage:

- A pre-project geotechnical study (G12), which identifies the major risks, ensures correspondence between the nature and depth of the ground and the indications on geological maps, and assesses the mechanical characteristics of each layer. It may recommend one or more foundation types.

- A project geotechnical study (G2).

- If the pre-project study (G12) has identified major risks, this next study must specify measures to be taken to limit their consequences (for example, carrying out a microgravimetric study recommending that the wind turbine should be moved or that karstic cavities should be injected under its land-take).

- In addition, this project study also requires the geotechnical engineer to ensure that the foundations meet the geotechnical requirements as well as those indicated in the wind turbine manufacturer's specifications. It must also define the moduli for the various deformation ranges.

At the "implementation" phase, this standard also includes:

- The geotechnical implementation study and followup (task G3);

- Geotechnical supervision for implementation (task G4).

\section{2}

\section{Information to be provided for the geotechnical engineer}

The contracting authority, assisted by the project manager, shall provide the geotechnical engineer with the following information (in accordance with paragraph $\S 3.47$ - Site data - of Standard NF EN 61400, June 2005):

- Details on where the project is to be constructed;

- Project surveying;

- Topographic map;

- Map of existing networks and list of concessionaires who may be involved (in France, see Demande de Renseignements [Decree 91-1147]);

- In France, specific risk plans: Plans Particuliers des Risques (PPR);

- Environmental criteria;

- Various load lowering values (in accordance with chapter 3 of these recommendations);

- Required values for:

- Settlement " $w$ ", deformations " $\varepsilon$ ", distortion " $\gamma$ ", and stiffness;

- Loads and stresses applied on the soil (if necessary).

\section{3}

\section{Geotechnical data}

The successive geotechnical studies allow the definition of:

- The geotechnical scope as defined in the Standard NF P 94 500, 2006 (geotechnical zone of influence, slope stability, etc.);

- Geological and stratigraphic information;

- Site hydrology and hydrogeology;

- Groundwater levels;

- Aggressiveness (water and soil);

- The geotechnical model describing the various layers to be taken into account, and defining layer by layer the following (non-exhaustive list):

- Thickness,

- Soil type (see Table 6 in $\$ 4.6 .5 .4$, and Standards ISO 14688-1 and 2, and ISO 14689-1 and 2),

- Permeability, if necessary,

- Mean limit pressure (PMT) or mean cone resistance (CPT),

- Moduli (see chapter 4.6):

$E_{y s t}$ for a deformation $\varepsilon$ of about $10^{-2}$ (often called "Young's modulus")

E or $\mathrm{G}$ for deformations $\varepsilon$ between $10^{-3}$ and $10^{-4}$

- Poisson's ratio $v$,

- Construction measures;

- Geotechnical design assumptions, types of foundation and their justifications (see $§ 4.6$ ).

\section{4.}

\section{Minimum site investigation except for anomaly zones}

Anomalies may be defined as any of the following examples (non-exhaustive list): Ground dissolution, quarry, municipal waste fill, karst, very thick fill, unstable zones, landslide zones, etc.

The surveying process is defined:

- By geologically homogeneous groups (or zones) and taking into account the number of wind turbines;

- By wind turbine.

\section{4.}

For a geologically homogeneous group (or zone)

\section{4.}

\section{Definition}

A geologically homogeneous zone is a site in which the geological nature and stratigraphy are considered to be homogeneous.

A wind turbine group is considered to be the number of turbines that are to be built in a homogeneous zone.

\section{6.}

\section{Coring with samples (NF EN ISO 22475-1)}

Coring and sampling shall be done so as a minimum of one sample of each geotechnical facies is retrieved. They enable at least: 
- Materials to be identified (disturbed or undisturbed samples);

- Geomechanical properties to be characterized (undisturbed samples): measurement of $\varphi^{\prime}$ and $c^{\prime}$ in accordance with Standard NF P94 074.

\section{4.}

\section{Piezometer (NF EN ISO 22475-1)}

A piezometer enables specific measurements to be made in real-time. Measurements are to be monitored as soon as possible before construction work begins.

The measurement conditions must comply with the standard. The following must be avoided:

- Clogged filters (filter covers and gravel fill);

- Meteoric water input (entering) at the top of the piezometer (The top of the piezometer must be properly protected from water ingress and shocks by a protective head).

The minimum duration of the survey is 12 months, with measurements at least once a month.

\section{7.}

\section{Geophysical tests}

These are described in the AGAP document entitled Code de Bonne Pratique en Géophysique Appliquée (French code for best practices in applied geophysics). In particular, the following tests shall be carried out: Cross-Hole, MASW, seismic cone or equivalent. They must enable:

- At least $V_{s^{\prime}}$ and even $V_{p}$ to be measured;

- And thus the shear modulus $G_{\max }$ at a distortion of $10^{-6}$, or even Poisson's ratio $v$ to be determined.

\section{twe}

\section{Minimum number and type of sounding}

Table 4 summarizes the number and type of sounding to be carried out.

\section{1.}

\section{Per wind turbine}

In addition, at least 4 soundings shall be carried out for each wind turbine (1 at the center and 3 on the periphery of its base [between 5 and $15 \mathrm{~m}$ from the center]), including:

-1 in situ sounding $[R]$ at the center, either;

- Using a pressuremeter, in accordance with Standard NF P94-110-1 with pressuremeter tests carried out every meter;
- Or using a CPT $\left(q_{c^{\prime}}, f_{s^{\prime}} R_{f}\right)$, in accordance with Standard NF P94-113.

Comment: It should be emphasized that ground water fluctuations may cause a significant variation in soil resistance. Test values measured in a potentially dry or unsaturated layer may drop when this layer subsequently becomes saturated.

- Three soundings [Q] chosen according to the soil type. In particular, these are used to verify soil homogeneity (depth, etc.) under the foundation land-take using;

- CPT $\left(\mathrm{q}_{\mathrm{c}^{\prime}}, \mathrm{f}_{\mathrm{s}^{\prime}}, \mathrm{R}_{\mathrm{f}}\right)$, in accordance with Standard NF P 94113;

- Or pressuremeter, in accordance with Standard NF P 94-110-1 with pressuremeter tests carried out every meter;

- boreholes with drilling parameters recording [see Reiffsteck, et al. (2010)];

- dynamic penetrometer, in accordance with Standard NF EN ISO22476-2 or standard penetration test (SPT) in accordance with Standard NF EN ISO22476-3;

- mechanical digger pit.

Comments: The definition of $[R]$ and $[Q]$ are given in the USG "Recommandations sur les investigations géotechniques pour la construction" (published by: Le Moniteur No. 5325 on Dec. 16, 2005) document. For interest:

- [R]: particularly well-adapted sounding test. This is to be carried out first;

- [Q]: sounding/test giving qualitative information. Only to be carried out in combination with other tests.

Soundings using a mechanical digger are recommended when the rocky substratum is near the surface.

\section{2.}

\section{Investigation depth}

\section{Th:}

\section{Coring surveys and soundings carried out at the center of each wind turbine location}

The soil survey must enable soil characteristics to be determined over a depth equal or greater to that in which the stresses induced by the foundation slab are still perceptible and cause significant deformations.

The survey depth under the foundation slab can be limited as follows:

- For shallow foundation slabs with a diameter $\varnothing$ (see Figure 2), the smallest of the two values;

TABEEW Minimum number and type of sounding per wind turbine group.

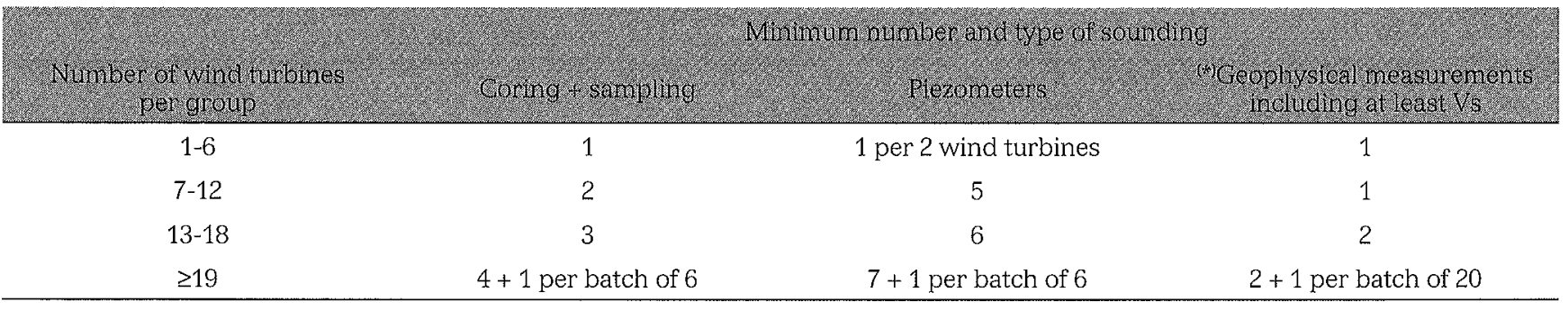

(*) According to soil classification zone (see. \$ 4.6.5). 
- 1.5 times the theoretical diameter of the foundation slab: $1.5 \varnothing$,

Comment: in accordance with the geological map, this limit of $1.5 \varnothing$ assumes that soil characteristics beyond this limit are greater or equal to those measured above and that soil deformation can therefore be disregarded. If this assumption is not proved, the survey must be continued.

- The depth to which soil moduli are sufficiently high to cause no further significant deformations of the foundation slab. This depth is increased by $5 \mathrm{~m}$,

Comments: For wind turbines $80-100 \mathrm{~m}$ high, a modulus value of $E_{y s t}$ greater than $100 \mathrm{MPa}$ can be considered.

For pressuremeter tests, a modulus value $E_{m}$ greater than 1,000 times the stress increase induced by the foundation can also be considered.

- For deep foundations with a diameter of $\Phi_{1}$, up to the largest of the following three values under the tip:

$$
7 \varnothing_{1}
$$

5 meters,

$\varnothing / 2$.

Comment: This last condition may provide an answer to the group effect problem.

- For hybrid (piled raft) or composite foundations, and for soil reinforced with rigid inclusions or stone columns with a diameter $\Phi_{1}$, the envelope depth of the two previous cases is taken.

\section{15 2}

\section{Other soundings on the periphery}

The soil survey must enable the homogeneity (depth, nature, etc.) of soils within the foundation's land-take to be verified. Its depth can thus be limited to the upper sound substratum or foundation horizon.

\section{2.}

\section{In case of anomaly}

In addition to the requirements given in the previous paragraph, and in accordance with Standard NF P94500 , it is advisable to carry out the above defined investigations in greater depth to identify the main significant risks. This requires case-by-case analysis, ensuring that all soil layers influencing the structure and affected by the anomalies are examined during the investigations.

\section{6}

\section{Geotechnical design parameters}

\section{4.}

\section{For deformations between $10^{-2}$ and $10^{-3}$}

The main design parameters to be provided for the relevant soil layers for the project are as follows:

- Classification calegories for the soil layers see § 4.6.5);

- Water levels to be taken into account in the calculations;
- Geomechanical failure characteristics defined using in-situ and laboratory tests (see Appendix F), for example:

- Net limit pressure $\mathrm{p}_{1}$,

- CPT tip resistance $q_{c^{\prime}}$

- Shear strength: $\varphi^{\prime}$ and $c^{\prime}$;

-The soil deformation parameters enable the calculation of the foundation slab's settlement and rotation according to the soil deformation level, namely:

- Values for the modulus of deformation $E$ and shear modulus G (see Figure 5) according to the level of deformation $\varepsilon$ for cases studied $\left(10^{-2}>\varepsilon>10^{-3}\right)$;

- Values for Poisson's ratio $v$.

Comments: For non-saturated soils, the short- and long-term Poisson's ratios $v$ are identical, lying between 0.20 and 0.35 .

For saturated soils:

- On the long-term, v must be 0.20-0.35,

- On the short-term, $v$ is usually 0.30-0.45.

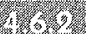

\section{For deformations between $10^{-3}$ and $10^{-4}$}

Under cyclic stresses, the mechanical characteristics of some soil types experience degradation. For example, this is associated with a gradual increase in interstitial pressure or soil attrition. The project geotechnical engineer must plan for this potential risk.

Soil surveying using standard in-situ tests must be completed by more detailed investigations to measure the following (see Figure 5):

- Parameters at a very low soil deformation level (see § 4.4.1.4: Geophysical tests);

- Parameters at a low soil deformation level using, for example, laboratory tests (resonant column and cyclic triaxial tests).

This enables the complete $\mathrm{E} / \mathrm{E}_{\max }$ and/or $\mathrm{G} / \mathrm{G}_{\max }$ curve to be estimated according to $\varepsilon$ and/or $\gamma$.

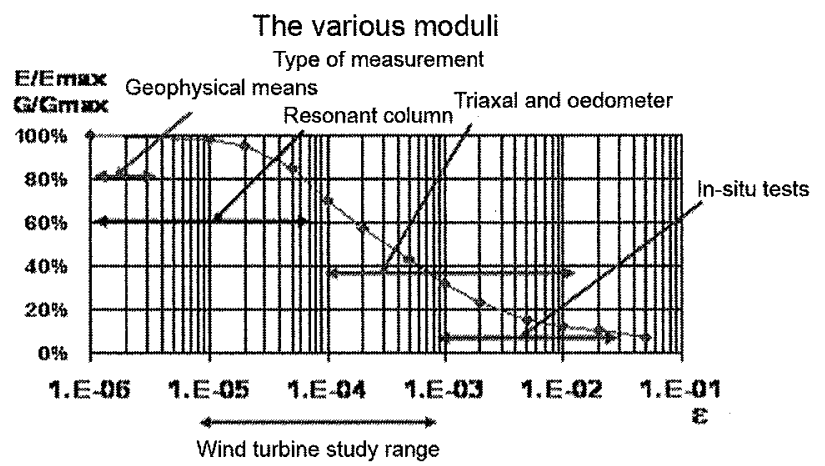

Comment: This diagram is only a representation of the various deformation ranges and should under no circumstances be used for design. See Appendix C for the degradation curves $G$ in function of distortion for clayey and granular materials. 
Comment:Itis useful to compare shear and compression waves velocities determined using geophysical measurements with the standard mean values in Table 5.2.1 of Standard NF P06-013 (called PS 92 Regulations), mentioned in Appendix C (Chapter C.2).

Among other uses, all or part of these parameters are required to calculate the various coefficients for vertical, horizontal and rotational stiffness.

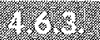

\section{Geotechnical data for footing design}

\section{6.}

\section{Bearing}

The limit pressure " $\mathrm{p}_{1}$ " or CPT " $\mathrm{q}_{\mathrm{c}}$ " values under the foundation slab must be known.

To calculate the bearing capacity, an equivalent limit pressure value " $\mathrm{p}_{\mathrm{le}}$ " or the equivalent penetrometer " $\mathrm{q}_{\mathrm{ce}}$ " value must be determined, calculated using previously measured values over a height of $1.5 \varnothing$ under the footing (see Appendix E.2 of Fasicicle 62-Title $V$ and $\S 3.2 .2$ of Standard NF P11-211 [DTU 13.11]).

We do not consider this method for determining average soil characteristics over $1.5 \varnothing$ under the footing to be entirely suitable for large-scale foundations. In particular, this is because the method limits the design value to 1.5 times the value of the lowest measured limit pressure value. We therefore suggest below a method for calculating $\mathrm{q}_{\mathrm{ce}}$ and $\mathrm{p}_{\mathrm{le}}$ that is suitable for this type of construction and that enables improved weighting of a low value's "weight" according to depth in relation the foundation slab base.

The values for $\mathrm{p}_{\mathrm{le}}$ and/or $\mathrm{q}_{\mathrm{ce}}$ according to a range of diameters $\Phi$ are established as part of a geological study.

\section{1.:}

Suggested calculation method $p_{l e}$ suitable for large-scale footings

To take into account variations in $p_{1}$ measurements over $1.5 \Phi$, the following $p_{1}$ calculation method can be used, which is based on the imaginary footing formula:

- At each level $\alpha_{i} \Phi$ ( $\alpha_{i}$ between 0 and 1.5) for a limit pressure measurement $p_{1}$, the imaginary footing formula is used with a diffusion of $1 \mathrm{H} / 2 \mathrm{~V}$ to determine the design limit pressure $p_{\mathrm{lc} i^{\prime}}$ such that $p_{\mathrm{lci}}=\mathrm{p}_{\mathrm{li}} \times\left[\left(1+\alpha_{\mathrm{i}}\right)^{2}\right]$

$-\mathrm{p}_{\mathrm{le}}=$ minimum of $\mathrm{p}_{\mathrm{li}} \times\left[\left(1+\alpha_{\mathrm{i}}\right)^{2}\right]$

thus calculated over a depth of $1.5 \Phi$

Comments: $\alpha \Phi$ corresponds to the top of the slice (see example in Appendix D). This method has the advantage of weighting the "weight" of a low value according to its depth in relation to the foundation slab base.

For a partially compressed footing, the calculations can be limited to $1.5 b^{\prime}$, with $b^{\prime}$ defined in Figure 6 and replacing $\varnothing$ by $b^{\prime}$ in equations 10 and 11 .

Comment: For homogenous soil characterized by variations in limit pressure between a maximum value $p_{\text {Imax }}$ and a minimum value of $p_{\text {Imin }}$ such that $p_{\text {Imax }} / p_{\text {Imin }}<2$, this calculation method can be simplified and $p_{l e}$ determined by taking a geometric mean and limiting the result to $1.5 p_{\text {Imin }}$.

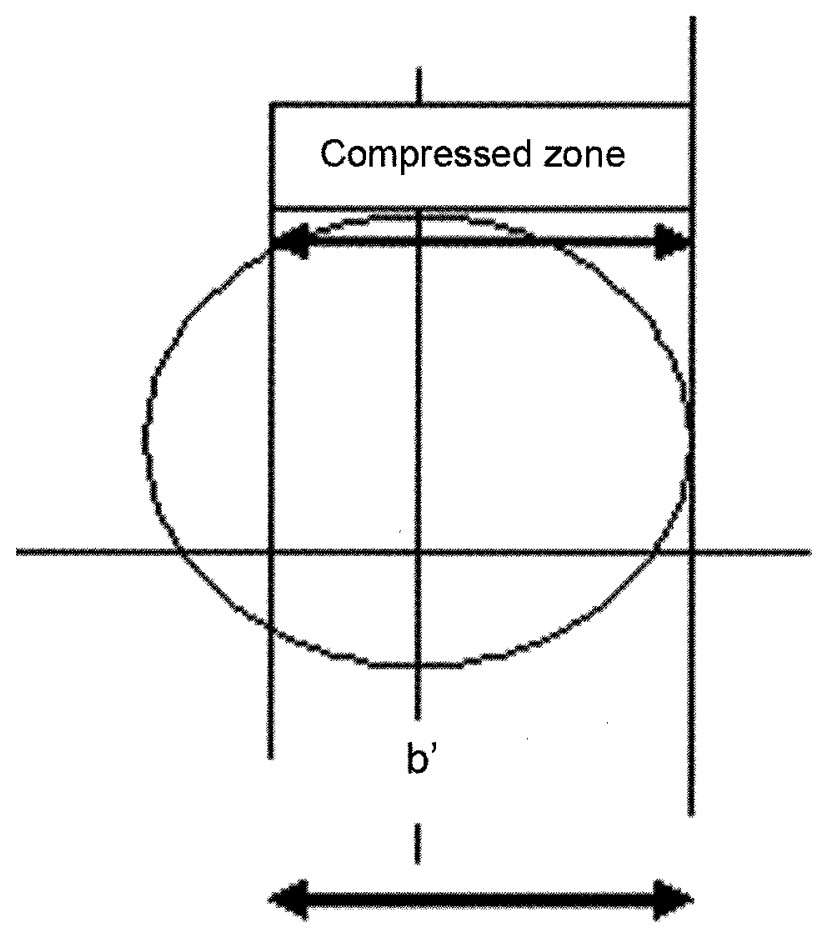

16. 6 Definition of the compressed zone width : $\mathrm{b}^{\prime}$ (see Appendix B).

\subsubsection{1 .}

Suggested method for calculating $q_{c e}$

To take account of $q_{c}$ variations over $1.5 \Phi$, please refer to the calculation method in Fascicule 62-Titre $\mathrm{V}$ (MELT 1993 and Appendix E2):

- The arithmetic mean is calculated for $q_{c}$ over $1.5 \Phi$;

- The values for $q_{c}$ are then reduced by a factor of 1.3 of this mean;

- The mean for the reduced values is then calculated, which is chosen as the $\mathrm{q}_{\mathrm{ce}}$ value.

Comment: For a partially compressed footing, these calculations are limited to $1.5 \mathrm{~b}^{\prime}$ (see Figure 5 and Appendix B).

For a soft layer with metric thickness.

The imaginary footing method is used, with $q_{\text {ce }}$ limited to the value measured as follows:

- At each measurement level $\alpha_{i} \Phi$ ( $\alpha_{i}$ between 0 and 1.5) of the penetrometer résistance value $q_{c i}$, the imaginary footing method is used with a diffusion of $1 \mathrm{H} / 2 \mathrm{~V}$, to determine the design penetrometer value $q_{\mathrm{cci}}$ such that $\mathrm{q}_{\mathrm{cci}}=\mathrm{q}_{\mathrm{ci} .}\left[\left(1+\alpha_{\mathrm{i}}\right)^{2}\right]$

$-q_{c e}=$ minimum of $q_{c i} \cdot\left[\left(1+\alpha_{i}\right)^{2}\right]$ thus calculated over a depth of $1.5 \Phi$;

\subsection{5.}

\section{Deformation}

\section{2 . 2 .}

Between $10^{-3}$ and $10^{-2}$

The settlement value $w$ is determined using standard soil mechanics methods:

- Laboratory test methods: essentially the oedometric test, especially for fine, coherent and saturated soils; 
- In-situ test methods: Ménard's pressuremeter test CPT test, widely used for granular soils in particular.

Comments: For Ménard's pressuremeter test, please refer to Appendix F2 of Fascicle 62-Title V (MELT, 1993) to estimate settlement $W$, and to Appendix F3 of the same Fascicle to estimate the vertical reaction modulus $K_{v s}$

For the CPT, the tip resistance $q_{c}$ is linked to the oedometric modulus $E_{\text {ocd }}$ and Young's modulus $E_{y s}$ (see $§ 4.6 .5$ ) by the following relationships:

$$
\begin{gathered}
E_{\text {oed }}=\alpha_{1} q_{c} \text { (for deformations of about } 10^{-2} \text { ) } \\
E_{\text {oed }}=E_{\text {yst }}(1-v) /[(1+v)(1-2 v)]
\end{gathered}
$$

Table 5 gives value ranges for $\alpha_{1}$ for various normally consolidated soil types and various $q_{c}$ values (Frank, 1996).

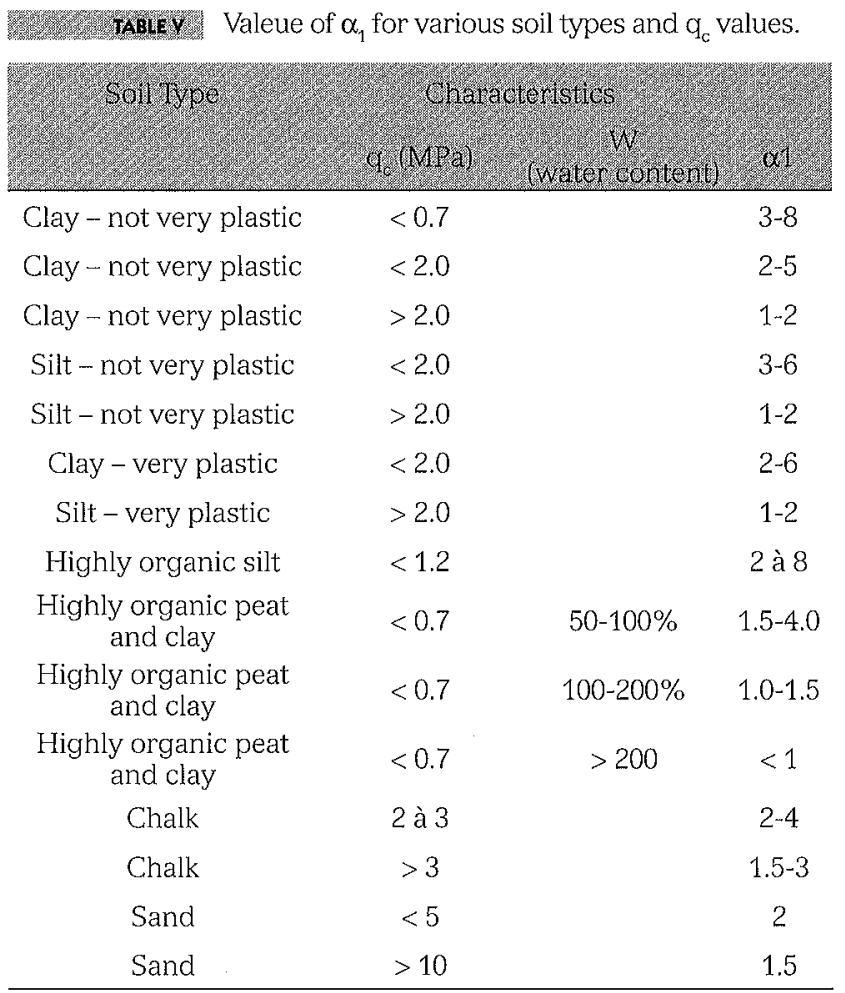

For static deformations between $10^{-3}$ and $10^{-2}$, the following need to be known:

- Either the pressuremeter characteristics enabling the following to be calculated:

- structural coefficient $\alpha$ in relation to the soil, spherical modulus $\mathrm{E}_{\mathrm{c}}$ and deviatoric modulus $\mathrm{E}_{\mathrm{d}}$ according to current practice,

- spherical settlement $\mathrm{w}_{\mathrm{c}^{\prime}}$ deviatoric settlement $\mathrm{w}_{\mathrm{d}^{\prime}}$

- total settlement w,

- $\mathrm{K}_{\mathrm{ys}}$ stiffness = static $\mathrm{q} / \mathrm{w}$ at short-term (ST) and long-term (LT).

- Or the CPT characteristics $\mathrm{q}_{\mathrm{c}^{\prime}}$ the $\alpha_{1}=\mathrm{E}_{\text {oed }} / \mathrm{q}_{\mathrm{c}}$ ratio, enabling the following to be calculated:

- total settlement w under a load causing stress q,

- $\mathrm{K}_{\mathrm{vs}}$ stiffness = static $\mathrm{q} / \mathrm{w}$ at ST and LT.

- Or the laboratory measured characteristics.

These various $\mathrm{K}_{\mathrm{vs}}$ ST and LT values are established as part of a geotechnical study.

\section{4.,}

Between $10^{-3}$ and $10^{-5}$

For a rigid disk supported by a semi-undefined homogenous elastic environment, extending a solution given by Boussinesq in 1885 for a central vertical load is successful for complex loads with the following moduli:

$$
\begin{gathered}
\mathrm{k}_{\mathrm{v}}=4 \mathrm{G} /(\pi \mathrm{r}[1-\mathrm{v}]) \text { in } \mathrm{N} / \mathrm{m}^{2} / \mathrm{m} \\
\mathrm{K}_{\mathrm{v}}=4 \mathrm{Gr} /(1-\mathrm{v}) \text { in } \mathrm{N} / \mathrm{m} \\
\mathrm{K}_{\varphi}=8 \mathrm{G} \mathrm{r}^{3} /[3(1-\mathrm{v})] \text { in } \mathrm{MNm} / \mathrm{rad} \\
\text { (see } \S 5.2 .3 .3 .1 .1 \text { ) }
\end{gathered}
$$

This elastic model is valid for a footing subject to a moment without offset and for short-term actions causing no consolidation or creep.

Comment: this is to be applied only in the case of a footing subject to a moment without lifting: $r$ can be identified at the disk radius. If an eccentric vertical stress is present, the width of the compressed zone is less than $2 r$. An equivalent radius $r^{*}$ to be defined must therefore be adopted (in principle, equal to the disk radius with the same inertia as the compressed zone).

The values under consideration for $G$ in the field of deformation are drafted as part of a geotechnical study.

\section{-}

\section{Data for piles, rigid inclusions and stone columns design}

In accordance with the current practices [Fascicle 62-Title V, MELT, 1993, "CFMS Stone-Columns Recommendations (2011)]") for justifying bearing capacity and settlements of piles, rigid inclusions and stone column (with length $L$ and diameter $\varnothing_{1}$ ) and foundation-slab rotation, soil surveying at the location of the structure must be done over a depth equal to $\mathrm{h}+$ $\mathrm{L}+$ maximum $\left(5 \mathrm{~m} ; 7 \emptyset_{1} ; \varnothing / 2\right.$, see $\left.\S 5.4 .1\right)$.

Comment: The geotechnical investigation is to be adapted when there is an identified anomaly risk (karst, quarry, etc.).

Successive geotechnical studies should make it possible to specify a standard cross-section, including the following data per layer:

- Ground type;

- Characteristic mean limit pressure or CPT values, enabling friction and lateral earth pressure to be calculated for the stone columns;

- Maximum value for the equivalent limit pressure $\left(\mathrm{p}_{\mathrm{l}}^{*}\right.$ ) or CPT $\left(\mathrm{q}_{\mathrm{ce}}\right)$ value, enabling the tip resistance to be calculated;

- Mean value for pressuremeter modulus, to calculate the friction mobilization;

- Mean value for structural coefficient $\alpha$, to calculate soil horizontal stiffness;

- Mean value for pressuremeter modulus under the tip, to calculate tip mobilization.$$
\text { 4. } 6
$$

\section{Soil classification areas}

Depending on the "typical static" deformation values (Young's modulus) $\mathrm{E}_{\text {yst }}$ (deformation between $10^{-3}$ and $10^{-2}$ ) and in situ tests (pressuremeter and/or CPT), three areas of study can be distinguished for a similar soil over a thickness of $1.5 \Phi$. 


\subsection{6.}

Area 1: $\mathrm{E}_{\mathrm{yst}}<15 \mathrm{MPa}$

In principle, shallow foundations cannot be envisaged unless specific modifications or reinforcement are made:

- If the layer in direct contact with the foundation slab is in area 1, this layer's soil characteristics do not allow for shallow foundations matching the deformation and rotation requirements prescribed by the special specifications of contractors. In this case, deep foundations are required. It may also be possible to consider adapting the shallow foundation system by soil substitution or reinforcement;

- If a soil layer in area 1 is at sufficient depth and is not very thick, it may potentially return to area 2 if a specific study is carried out.

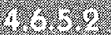

\section{Area 2: $15 \mathrm{MPa} \leq \mathrm{E}_{\text {yst }} \leq 50 \mathrm{MPa}$}

For a multilayer with a depth equal to 1.5 times the foundation slab diameter, the project is in area 2 if one of the layers is in area 2 and if there is no area 1 layer.

If a soil layer in area 1 is at sufficient depth but is not very thick, it may potentially return to area 2 if a specific study is carried out.

The mere definition of "typical static" deformation modulus $E_{\text {yst }}$ does not allow a shallow foundation system to be kept in working order. Nevertheless, a shallow foundation principle is not excluded.

- Soil surveying using standard in situ tests must be completed by more detailed investigations ( $\$ 4.6 .2)$ to measure the parameters at a very low soil deformation level and thus estimate the complete $\mathrm{E} / \mathrm{E}_{\max }$ and/or $\mathrm{G} / \mathrm{G}_{\max }$ curve according to $\varepsilon$ and/or $\gamma$

- Soil reinforcement may also be considered.

Comment: For this example of shallow foundations on reinforced or substituted soil, and as part of hybrid or composite foundations, the investigations detailed in $\$ 4.6 .2$ can be dispensed.

\section{63}

For a pre-design study

The following correlation between the "static" moduli and maximum moduli for very slight deformation (about 10-6), called "dynamic" moduli, can be used (see $\$ 3.5 .5 .2$ ):

$\mathrm{G}_{\max }=10 \mathrm{G}$, with a "static" $\mathrm{G}$ modulus for deformations of $10^{-2}$

$\mathrm{E}_{\max }=10 \mathrm{E}_{\mathrm{yst}^{\prime}}$ with a $\mathrm{E}_{\mathrm{yst}}$ "static" modulus for deformations of $10^{-2}$

For correlations using pressuremeter tests, the following can be chosen:

$$
\mathrm{G}_{\max }=(6-8) \mathrm{E}_{\mathrm{m}}
$$

By default, for the deformation rates considered for wind turbines $\left(\varepsilon \approx 10^{-3}\right.$ to $10^{-4}$ ) are:

$\mathrm{G}_{\mathrm{at} 10}{ }^{-4} / \mathrm{G}_{\max }=0.33$ for clayey and compact material (22) $\mathrm{G}_{\mathrm{at10}}{ }^{-4} / \mathrm{G}_{\max }=0.50$ for compact sandy/gravel material (and weathered rocks).

For other materials, interpolation is possible.
Pre-design taking into account more favorable values than those obtained by the above correlations must undergo the tests described in chapter 4.6.5.2, paragraph 4.

\section{5}

Area 3: $\mathrm{E}_{\mathrm{yst}}>50 \mathrm{MPa}$

A shallow foundation principle is entirely conceivable for wind turbines. It is sufficient to carry out the soil survey giving "typical static" deformation moduli $\mathrm{E}_{\mathrm{yst}}$.

For the project to be in area 3 , all layers over a depth equal to 1.5 times the foundation slab diameter must be in area 3.

If a soil layer in area 2 is at sufficient depth but is not very thick, it may potentially return to area 3 if a specific study is carried out.

\section{6.}

\section{Classification}

By taking up the soil types in Fascicle 62-Title V (MELT, 1993), we suggest the areas classification described in the "Study Areas Summary" table.

In practice, at a height of 1.5 times the width of the foundation slab $\Phi$, it is advisable to define the various soil layers with homogeneous geological and mechanical characteristics.

The average characteristics for these various soil layers are determined as follows:

$\mathrm{q}_{\mathrm{cEq}}$ and $\mathrm{E}_{\mathrm{mEq}}$ are calculated by establishing the harmonic mean (for $q_{c}$ and $E_{m}$ respectively) over the height of the layer being examined, and limited to 1.5 times the lowest measured value.

\section{Different foundation types}

\section{1}

\section{General observations}

\section{Then \\ Introduction}

A wind-turbine foundation slab has generally a polygonal shape and is similar to a circular foundation slab with the same surface area and diameter $\varnothing$. It generally has a horizontal base and is found at an embedding depth of $h$ from the surface.

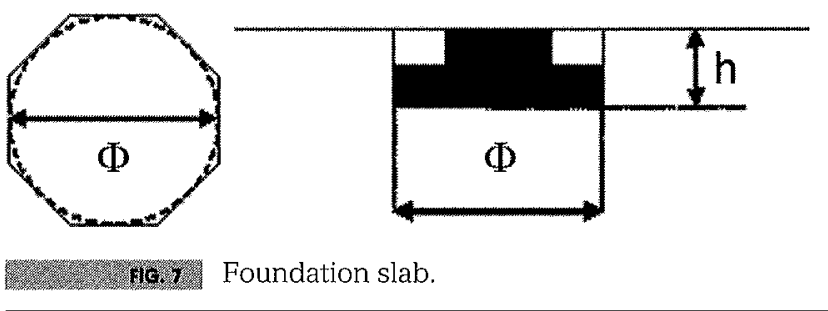

It can be built as follows (see $§ 1.1 .1 .4$ ):

- Without soil reinforcement: this is a "gravity-base" (\$ 5.2);

- On soil reinforced with stone columns (SC) (§ 5.3); 
20. TABE

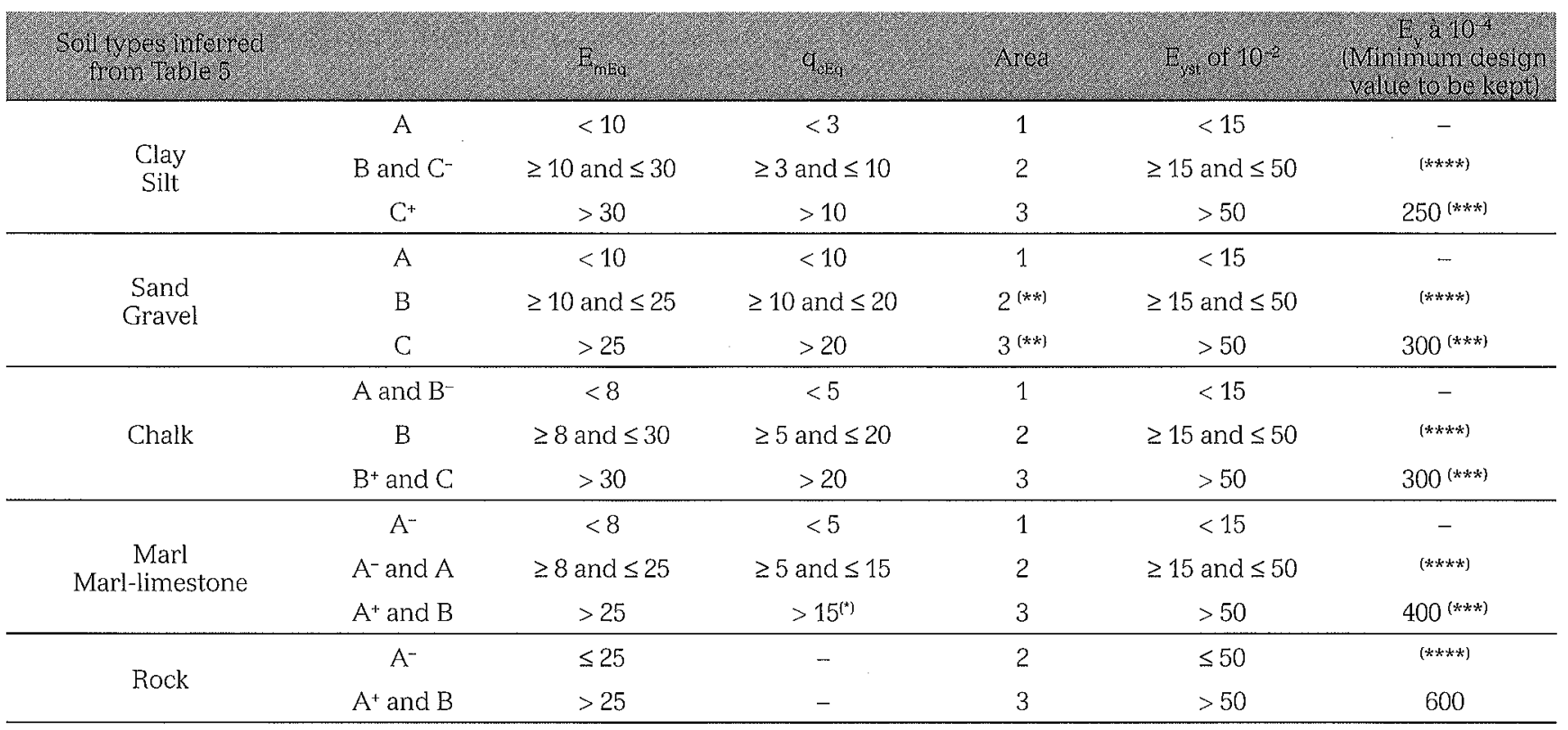

") As well as additional tests, if refusal is encountered.

"') As well as liquefaction test under cyclic stresses if $\mathrm{D}_{10}$ (diameter at $10 \%$ passing) < 2 mm (Standard NF P 06-013-PS 92, Article 9.122)

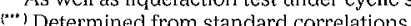

(…) Vetermined from standard correlations.

$A^{-}, A^{+}, B^{-}, B^{+}, C^{-}, C^{+}$additional categories to those suggested in Fascicule 62-Title $V$

The correlations between $E_{y s 1}$ and $E_{n 1}$ are given conservatively and include a fatigue phenomenon associated with cyclic stresses.

- On soil reinforced with rigid inclusions (RI) (\$5.4);

- On piles: these are deep foundations (\$5.5);

- On "hybrid" or "composite" foundations (\$5.6).

Comment: Reinforcement by hybrid columns solutions (rigid inclusion surmounted with a stone column head) must comply with both stone column and rigid inclusion recommendations and arrangements, as described in $§ 5.3$ and 5.4 .

Comment: For soils with mechanical characteristics that are likely to change significantly over time (tips, poorly consolidated embankments, silt, peat, etc.), it is preferable to choose deep foundations or gravity bases after soil substitution.

\section{6.}

\section{General construction measures}

\section{.}

\section{For ground water}

If ground water is present, its effect is always taken into consideration. The water levels to be taken into account are established as part of a geotechnical assignment.

\section{5.}

\section{For surface water}

If there is a risk of water accumulation and ground saturation to a level higher than the foundation base, the water level is taken into account unless permanent gravity drainage can be justified.

Comment: The water levels to be taken into account according to site topography, stratigraphy, permeability of the various soil layers and the zone's pluviometry are established as part of a geotechnical study.

\section{(3)}

\section{For weathering of the excavation bottom}

After the bottom of the excavation has been validated by geotechnical works supervision (Stage 3 Standard NF P94-500), measures required to protect the bottom of the excavation during construction work are to be implemented.

Depending on the foundation used, either blinding concrete, a work-platform protective layer or a foundation support layer are made. Construction measures required to ensure that this protective layer is not contaminated by the supporting soil at the bottom of the excavation are to be implemented (geotextile, anti-contamination layer, etc.).

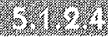

\section{For soil passive pressure}

Please refer to paragraph 3.5.3.

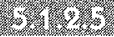

\section{Minimum reinforcement length (SC, $\mathrm{RI}$, or piles)}

Except for special justifications, the minimal reinforcement length is the ground height in area 1 and/or 2.

\subsection{4}

\section{General verification and inspection}

Current regulations apply and are completed by the following. 


\section{3.}

\section{Concrete foundation slab}

The contract documents specify the number and nature of samples. The recommended frequency of sampling is at least the following:

- 1 sample per $100 \mathrm{~m}^{3}$ of concrete installed;

- 1 sample per wind turbine;

-6 specimens per sample. 206.

Concrete characteristics must comply with NF EN

\section{6.}

\section{For bearing and weathering of the excavation bottom}

At the end of the excavation, the geotechnical model is checked by the geotechnical engineer for conformity with soil type and homogeneity at the bottom of the excavation.

If there are differentsub-base levels, the geotechnical engineer ensures conformity with stepping rules.

If new material is brought in, its classification and bearing must be defined and checked by the geotechnical engineer.

\section{3.}

\section{For hydraulic assumptions}

The validity of the hydrogeological model, especially for the absence of surface water accumulating on the foundation slab, is verified by the geological engineer.

\section{2}

\section{Gravity bases}

\section{1.}

\section{Description}

A wind-turbine foundation slab is generally polygonally shaped and is similar to a circular foundation slab with the same surface area and diameter $\varnothing$. It generally has a horizontal base and is found at an embedding depth of $\mathrm{h}$ from the surface.

The footings are considered to be infinitely rigid.

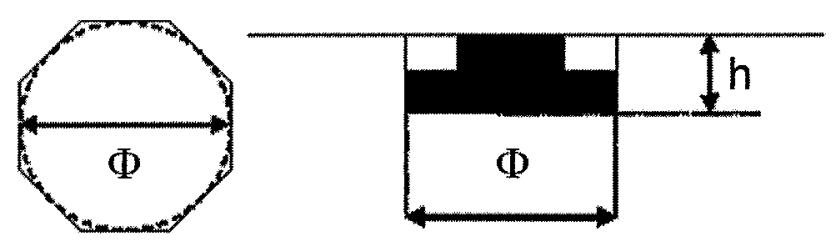

178. 8 Wind-turbine foundation slab.

Chapter 5.2 applies to both gravity bases made directly on natural soil and also to gravity bases made on soil whose "mass" has been substituted or improved by specific techniques not covered by these recommendations (dynamic compaction, vibroflotation, solid injection).

\section{(6)}

\section{Geotechnical data}

In accordance with Fascicle 62-Title V (MELT 1993), justifying the bearing and calculating the settlement and rotation of a foundation slab requires knowledge of the soil over a theoretical height equal to $h+8 \varnothing$. This height may be limited for wind-turbine foundation slabs with values described in $§$ 4.4.3.1.

The bearing capacity is calculated from an equivalent limit pressure $\mathrm{p}_{\mathrm{le}}{ }^{*}$ or an equivalent penetrometer value $\mathrm{q}_{\text {ce. }}$

These values for $\mathrm{p}_{\text {le }}$ and/or $\mathrm{q}_{\mathrm{ce}}$ according to a range of diameters $\Phi$ are given as part of a geotechnical study.

\section{6.}

Justifications

\section{5}

\section{Bearing}

The bearing capacity is calculated by applying current regulations (example: pressuremeter and penetrometer regulations) at SLS and ULS.

For all SLS and ULS load charges, the following are calculated: $\sigma_{\text {max }}, \sigma_{\min }$ and $\mathrm{q}_{\text {ref }}=\left(3 \sigma_{\max }+\sigma_{\min }\right) / 4$ in accordance with $\S 3.5 .2$.

For the maximum constraint $\mathrm{q}_{\text {ref }}$, verify that:

$$
\begin{aligned}
& \mathrm{q}_{\text {ref }}<\mathrm{i}_{\delta \beta} \mathrm{k}_{\mathrm{p}} \mathrm{p}_{\mathrm{le}}{ }^{*} / \gamma_{\text {soil }}+\mathrm{q}_{\mathrm{o}}^{\prime} \\
& \mathrm{q}_{\text {ref }}<\mathrm{i}_{\delta \beta} \mathrm{k}_{\mathrm{c}} \mathrm{q}_{\mathrm{ce}} / \gamma_{\text {soil }}+\mathrm{q}_{\mathrm{o}}^{\prime}
\end{aligned}
$$

where $\gamma_{\text {soil }}$ is the partial factor of safety under footings in current regulations.

Comment: $i_{8 \beta}$ is calculated in conformity with current standards according to the applied load inclination and to the proximity of an embankment slope.

Comment: For pressuremeter tests, ensure that the maximum pressure applied on the soil is not exceeded by the creep pressure $p_{f}$.

\section{9}

\section{Settlement}

\section{Overall settlement}

For static deformations between $10^{-3}$ and $10^{-2}$ under a charge causing a constraint $q$, the settlement $w$ can be calculated. This enables the ST and LT static stiffness $K_{v s}=q / w$ to be determined.

Remember that these ST and LT values for $\mathrm{K}_{\mathrm{vs}}$ are given as part of a geotechnical study.

\section{(5)}

\section{Rotation}

Rotation is defined using the widths given in Figure 9 by the following formula:

$$
\varphi=\left(h_{2}-h_{1}\right) / \Phi
$$

The rotational stiffness is defined as $K_{\varphi}=M / \varphi$ 

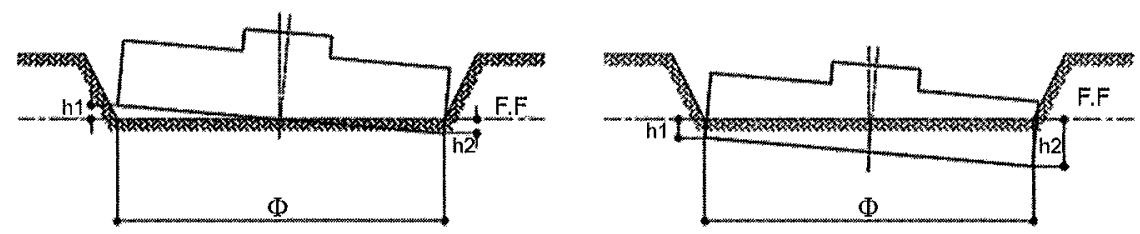

Diagram of rotation in a gravity-base foundation slab.

The specific case of completely compressed soil

The following table below gives the literal expressions enabling coefficient values for the spring stiffness to be determined for rigid circular foundation slabs with a radius $r$ in a perfectly homogenous, elastic, semi-infinite and isotropic medium.

$$
\text { With } \mathrm{G}=\mathrm{E} /[2(1+\mathrm{v})]
$$

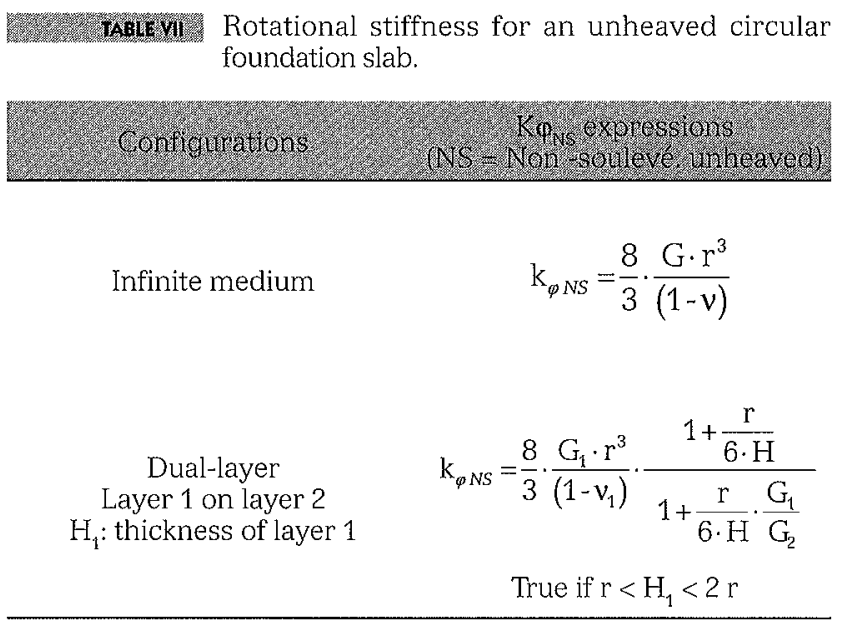

Comment: These expressions are related to the main inertia axis and are only valid if the soil remains compressed under the entire circular foundation with a radius $r=\Phi / 2$.

Remember that in quasi-permanent SLS (obtained from $\mathrm{DLC}_{\mathrm{OP}}$ load cases), the soil under the footing must always be completely compressed.

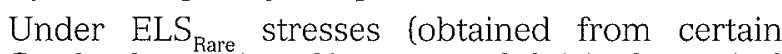
$\mathrm{DLC}_{\text {Rare }}$ loads mentioned in paragraph 3.4.1-theoretical situations 1 and 2), the soil may not be completely compressed. In this case, $\mathrm{K}$ must be weighted with a coefficient $\beta_{1}$ (see $\$ 3.5 .5 .1$ and Figure 4) that depends on the percentage of completely compressed soil under the footing.

\section{6.}

\section{Sliding failure}

Please refer to paragraph 3.5 .3 of these recommendations.

\section{3.}

\section{Gravity bases on soil reinforced with stone columns}

This chapter applies exclusively to soil reinforcement using stone columns under wind-turbine foundation slabs. These footings are considered to be infinitely rigid.
The stone columns are made and inspected according to the "CFMS Stone-Column Recommendations (2011)" and Standard NF EN 14731 (Improving soil foundation by deep vibration). The recommendations in this document supplement these reference documents, taking into account the specific aspects of wind-turbine foundations. If there are divergent recommendations, the least favorable condition or method must be used.

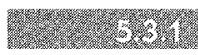 \\ Description}

This type of soil reinforcement involves installing a group of vertical columns made of granular, cohesionless material. They are installed by soil displacement and compacted by successive passes.

These columns pass through compressible soil to improve and homogenize soil conditions under the foundation.

In addition to paragraph 4.2 of the "CFMS StoneColumn Recommendations (2011)", the specific case of wind turbines requires load transfers (especially shear) via a load-transfer platform on the underside of the foundation slab.

Comment:If the stone columns are made at the bottom of the excavation on a work platform consisting of natural gravel, this platform can be integrated into the load-transfer platform. If the stone columns are made on the natural ground before excavation, it is advisable to lay a load-transfer platform between the column heads and foundation underside.

Soil treatment with stone columns combines the following actions, one or more of which can be explored:

- Improving bearing and reducing settlement;

- Increasing the equivalent characteristics of the foundation slab on treated soil (horizontal shear strength, internal friction angle and deformation parameters).

A stone column is a soil reinforcement procedure: it is not a foundation component or a deep foundation. The foundations of a structure supported by soil treated with stone columns are always considered as shallow.

The soil reinforcement design parameters are as follows:

- Depth L of the stone columns;

- Cross-sectional area of these inclusions and/or their equivalent diameter $\Phi_{1}$ in each of the layers crossed;

- Allowable stress in the stone column (depends on the mechanical characteristics of the surrounding soil), and its deformation characteristics (modulus of deformation, Poisson's ratio, etc.);

- Number of columns;

- Column mesh, or the reinforcement incorporation ratio $\beta$, which represents the ratio of area covered by column heads to total surface treated area; 
- Load-transfer platform characteristics:

- Thickness $\mathrm{H}_{\text {plat }}$

- Intrinsic characteristics: $c^{\prime}$ and $\varphi^{\prime}$,

- Deformation modulus E and shear modulus G,

- Compactness.

\section{3.}

\section{Geotechnical data}

Please refer to chapter 4: "Geotechnics and design parameters" of these recommendations.

To justify the bearing and calculate the settlement and rotation of this foundation slab on reinforced soil, the geotechnical data must combine:

- The requirements of chapter 5.2.1 on the gravity bases, and;

- The specific requirements for calculating stone column bearing, namely knowledge of the soil over a height equal to $L+\max \left(5 \mathrm{~m} ; 7 \Phi_{1}\right)$.

Successive geotechnical studies must enable a standard cross-section to be specified, with all the soil parameters listed in paragraphs 4.6.1 and 4.6.2 per approximately homogenous layer.

Comment: Remember that the $p_{l}^{*}$ or $q_{c}$ values for calculating the lateral earth pressure of the stone column must be given as part of a geotechnical study.

\section{35}

\section{Stone-column operation}

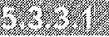

\section{General principles}

The following assumptions are made:

- Loads applied by the foundations are distributed between the soil and stone columns according to the vertical stiffness and incorporation ratio via diffusion of stresses through the load-transfer platform;

- Loading of stone columns, and hence overall load distribution, is limited by mobilizable lateral earth pressure of the surrounding ground (lateral earth pressure is a function of the limit pressure, or CPT tip resistance; see chapter 5.4.1 of the "CFMS StoneColumn Recommendations [2011]).

\section{1.t. 6.}

\section{Areas of application}

For wind-turbine projects, stone columns should not be used in compressible soil that cannot guarantee sufficient lateral confinement.

We draw attention to the difficulty of justifying allowable stresses in the soil and columns (mainly ULS stresses), unless the foundation slab diameter can be increased to significantly reduce the stresses applied under the foundation.

Comment: In compressible soil, it is usually difficult to justify a foundation slab on stone columns with a soil bearing capacity under the foundation slab greater than $250 \mathrm{kPa}$ ( 2.5 bars) at SLS, and greater than $350 \mathrm{kPa}$ (3.5 bars) at ULS.

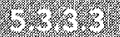

\section{The aims of soil reinforcement}

Soil reinforcement aims to provide reinforced soil with the mechanical characteristics required for constructing a wind turbine on a foundation slab with ordinary weight. The foundations must behave as on homogeneous soil.

The following parameters thus need to be determined to design the foundation slab:

- Parameters for calculating SLS/ULS bearing capacity on reinforced soil;

-Foundation reaction coefficients $\mathrm{K}_{\mathrm{v}}$ and $\mathrm{K}$ or equivalent $\mathrm{ST}$ or LT deformation moduli $\mathrm{E}_{\text {eq }}$ for reinforced soil;

- Parameters for sliding failure, especially the friction angle $\varphi$ of soil under the foundation (which corresponds to the foundation's friction angle on the load-transfer platform);

- Equivalent Poisson's ratio $v_{\text {eq }}$ for reinforced soil;

- Equivalent dynamic shear modulus $G_{\text {dyneq }}$ for reinforced soil in the deformation range $10^{-3}$ to $10^{-4}$ and the dynamic rotational stiffness ratio $K_{\text {cpdyn }}$ of the foundation on the reinforced soil.

\section{S.t.}

\section{Justifications}

\section{1.}

\section{Bearing verification}

When the design calculations are carried out, the stress distribution between the soil and the stone columns must be verified for all stone columns, to ensure that the limit values for $\mathrm{q}_{\mathrm{S}}$ under the footing and $\mathrm{q}_{\mathrm{a}} / \mathrm{q}_{\mathrm{aULS}}$ in the columns are not exceeded (see definition of $\mathrm{q}_{\mathrm{a}}$ and $\mathrm{q}_{\mathrm{a} u L S}$ in paragraphs 5.4 .4 and 5.4 .5 of the "CFMS Stone-Column Recommendations").

In all SLS and ULS cases, the $S_{\text {comp' }} \sigma_{\text {max }} \sigma_{\min }$ and $\mathrm{q}_{\text {ref }}=\left(3 \sigma_{\max }+\sigma_{\text {min }}\right) / 4$ are calculated according to $\S 3.5 .2$.

Comment: For a column to be taken into account in the overall bearing calculation, its presence in the completely compressed imaginary soil section must be verified, as set out in $\S 3.5 .2$ and illustrated in Appendix $B$.

To take account of the specific character of windturbine foundations, the local and overall bearing requirements described in the following paragraphs must be verified for all load cases by pressuremeter and penetrometer methods.

\section{2.}

\section{Overall bearing requirements}

The following overall bearing requirement is verified for all SLS and ULS load cases, with:

$$
\begin{gathered}
\mathrm{q}_{\text {soilELS }}>\left(\mathrm{q}_{\text {refSLS }} \mathrm{S}_{\text {comp }}-\mathrm{nQ}_{\text {colSLS }}\right) /\left(\mathrm{S}_{\text {comp }}-\mathrm{n} \mathrm{A}_{\mathrm{p}}\right) \\
\mathrm{q}_{\text {soileLU }}>\left(\mathrm{q}_{\text {refULS }} \mathrm{S}_{\text {comp }}-\mathrm{n}_{\text {colULS }}\right) /\left(\mathrm{S}_{\text {comp }}-\mathrm{n} A_{\mathrm{p}}\right)
\end{gathered}
$$

$\mathrm{n}=$ number of columns under the reference surface area $\mathrm{S}_{\text {ref }}$ illustrated in Appendix B:

$$
\begin{aligned}
& Q_{\text {colSLS }}=A_{p} q_{a S L S} \\
& Q_{\text {colULS }}=A_{p} q_{a U L S}
\end{aligned}
$$


With pressuremeter or penetrometer methods, the following are used respectively:

$$
\begin{aligned}
& \mathrm{q}_{\text {soilSLS }}=\mathrm{k}_{\mathrm{p}} \mathrm{p}_{\text {le }} / \gamma_{\text {soiluLS }}+\mathrm{q}_{\mathrm{o}}^{\prime} \text { or } \mathrm{q}_{\text {soiluLS }}= \\
& \mathrm{k}_{\mathrm{c}} \mathrm{q}_{\mathrm{ce}} / \gamma_{\text {soiluLs }}+\mathrm{q}_{\mathrm{o}} \\
& \begin{array}{c}
\mathrm{q}_{\text {soilsLS }}=\mathrm{k}_{\mathrm{p}_{\mathrm{c}}} \mathrm{p}_{\text {le }} / \gamma_{\text {soilSLS }}+\mathrm{q}_{\mathrm{o}}^{\prime} \text { or } \mathrm{q}_{\text {soilsLS }}= \\
\mathrm{k}_{\mathrm{c}} \mathrm{q}_{\mathrm{c}} / \gamma_{\text {soilsLS }}+\mathrm{q}_{\mathrm{o}}^{\prime}
\end{array}
\end{aligned}
$$

with $\gamma_{\text {soilsLS }}=3$ and $\gamma_{\text {soiluLS }}=2$

\section{1.}

Local bearing requirements

The following must be verified for all load cases (SLS and ULS), mesh by mesh:

The following soil bearing requirements:

$$
\begin{gathered}
q_{\text {soilsLS }}>\left(q_{\text {refSLS }} S_{\text {mesh }}-Q_{\text {colsLS }}\right) /\left(S_{\text {mesh }}-A_{p}\right) \\
q_{\text {soilULS }}>\left(q_{\text {refULS }} S_{\text {mesh }}-Q_{\text {colULS }}\right) /\left(S_{\text {mesh }}-A_{p}\right) \\
Q_{\text {colsLS }}=A_{p} q_{\text {aSLS }} \\
Q_{\text {colULS }}=A_{p} q_{\text {aULS }}
\end{gathered}
$$

With pressuremeter and penetrometer methods, the following equations are used respectively:

$\mathrm{q}_{\text {soiluLS }}=\mathrm{k}_{\mathrm{p}} \cdot \mathrm{p}_{\mathrm{le}} / \gamma_{\text {soiluLS }}+\mathrm{q}_{\mathrm{o}}^{\prime}$ or $\mathrm{q}_{\text {soiluLS }}=\mathrm{k}_{\mathrm{c}} \cdot \mathrm{q}_{\mathrm{ce}} / \gamma_{\text {soilULS }}+\mathrm{q}_{\mathrm{o}}^{\prime}$ $\mathrm{q}_{\text {soilsLS }}=\mathrm{k}_{\mathrm{p}} \cdot \mathrm{p}_{\text {le }} / \gamma_{\text {soilsLS }}+\mathrm{q}_{\mathrm{o}}^{\prime}$ or $\mathrm{q}_{\text {soilSLS }}=\mathrm{k}_{\mathrm{c}} \cdot \mathrm{q}_{\mathrm{ce}} / \gamma_{\text {soilSLS }}+\mathrm{q}_{\mathrm{o}}^{\prime}$ with $\gamma_{\text {soilsLS }}=3$ and $\gamma_{\text {soiluLS }}=2$.

The following settlement requirements at SLS, to ensure that they remain elastic:

$$
\mathrm{q}_{\mathrm{app}}^{\prime}<\mathrm{k}_{\mathrm{p}} \mathrm{p}_{\mathrm{le}} / \gamma+\mathrm{q}_{\mathrm{o}}^{\prime} \text { or } \mathrm{q}_{\mathrm{app}}^{\prime}<\mathrm{k}_{\mathrm{c}} \mathrm{q}_{\mathrm{ce}} / \gamma+\mathrm{q}_{\mathrm{o}}^{\prime}
$$

where $q^{\prime}$ app is the mean stress taken up by the soil over the mesh.

The following stress requirements in the columns:

$\mathrm{q}_{\mathrm{col}}<\mathrm{q}_{\mathrm{aSLS}}$ at SLS limited to a minimum $\left(\mathrm{q}_{\mathrm{re}} ; \mathrm{q}_{\mathrm{rp}}\right.$; $1.6 \mathrm{MPa}) / 2$;

$\mathrm{q}_{\mathrm{col}}<\mathrm{q}_{\mathrm{auLS}}$ at ULS limited to a minimum $\left(\mathrm{q}_{\mathrm{re}} ; \mathrm{q}_{\mathrm{rp}}\right.$; $1.6 \mathrm{MPa} / 1.5$;

$\mathrm{q}_{\mathrm{aSLS}}$ : maximum allowable stress in the column at SLS; $\mathrm{q}_{\mathrm{aULS}}$ : maximum allowable stress in the column at ULS; $\mathrm{q}_{\mathrm{re}}$ and $\mathrm{q}_{\mathrm{r}}$ : see definitions $\S 5.4$ in the "CFMS StoneColumn Recommendations (2011)".

\section{1.}

\section{Sliding failure}

The stone columns enable an increase in the equivalent characteristics of the foundation slab on treated soil: horizontal shear strength, internal friction angle, and potentially the deformation parameters.

The shear stresses at the footing underside are distributed through the load-transfer platform according to the friction under the footing, and thus in proportion to the distribution of compressed vertical stresses:

$\sigma_{\text {col }}$ in the stone column;

$\sigma_{\mathrm{s}}$ outside this stone column's land-take.

They therefore only apply on soil or columns bearing under compression, especially in the case of overturning moments on the footing.

In the case of a footing subject to a torque $(Q, M$, $\mathrm{H}_{\mathrm{UL}}$ ), only those columns bearing under compression are taken into account in the verification.

According to the share of the total load taken up by the soil and by the stone columns respectively, the equivalent shear strength can be determined from the internal friction angles for the entire soil/column structure.

With

$$
\tan \varphi_{\mathrm{eq}}=\mathrm{m}^{\prime} \tan \varphi_{\mathrm{c}}+\left(1-\mathrm{m}^{\prime}\right) \tan \varphi_{\mathrm{s}}
$$

$$
\begin{gathered}
m^{\prime}=(n-1) / n \\
n=\text { improvement factor }=\sigma_{\text {app }]} / \sigma_{\text {soil }}
\end{gathered}
$$

Please refer to the comments in paragraph 3.5.3, replacing $\varphi^{\prime}$ with $\varphi_{\mathrm{eq}}$.

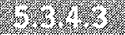

\section{Calculating deformations}

The foundation's settlement and rotation are calculated using equivalent reinforced soil characteristics for short-and long-term loads according to the principles set out in $\S 5.2 .3$.

\section{6.}

\section{Intrinsic behavior of stone columns}

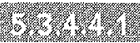

\section{Maximum allowable stress in the columns}

Calculating the maximum allowable stress requires vertical failure stress $q_{r}$ of an isolated column from column material characteristics and those of the surrounding soil to be determined for the following potential failures mechanisms:

- Lateral expansion failure (often a design requirement); - Punching failure (floating columns).

\subsection{1.}

Stone-column static deformation modulus of $10^{-2}$

This modulus equals a maximum of 10 times the modulus for the surrounding ground. According to paragraph 5.3 of the "CMFS Stone-Column Recommendations (2011)", it can be taken equal to $\mathrm{E}=$ $60 \mathrm{MPa}$ if the columns comply with the compactness requirements:

$$
\begin{aligned}
& \mathrm{q}_{\mathrm{cm}}>10 \mathrm{MPa} \\
& \mathrm{p}_{\mathrm{l}}>1.2 \mathrm{MPa} \\
& \mathrm{q}_{\mathrm{d}}>10 \mathrm{MPa}
\end{aligned}
$$

\section{5.}

"Dynamic" stress of $10^{-4}$ in the stone column

If the columns respect the above minimum compactness requirements, the shear modulus of $10^{-4}$ in the stone columns may be taken equal to:

$$
\mathrm{G}_{\text {coldyn }}=0.55 \mathrm{G}_{\max }=55 \mathrm{MPa}
$$

Comment: This value is obtained from the following correlations: $G_{\max }=7 E_{m^{\prime}} E_{m}=15 \mathrm{MPa}, G_{\text {coldyn }} / G_{\max }=$ 0.55 to $10^{-4}$.

\section{5.}

\section{Calculating equivalent "dynamic" characteristics for reinforced soil}

For deformation between $10^{-3}$ and $10^{-4}$ a simplified assumption is adopted, according to which shear 
deformations in the soil and stone columns are equal, and the equivalent shear modulus of the soil-column system is thus written (see $\S 4.6 .2$ and 5.3.4.4.3):

$$
\begin{gathered}
G_{\text {ect }}=\beta \cdot G_{\text {coldyn }}+(1-\beta) \cdot G_{\text {soildyn }} \\
\beta: \text { substitution rate }=A_{\text {col }} / S_{\text {mesh }} \\
A_{\text {col }} \text { : stone column area; } \\
S_{\text {mesh }} \text { column mesh surface area. }
\end{gathered}
$$

This value of $\mathrm{G}_{\mathrm{eq}}$ at $10^{-4} \mathrm{~m}$ enables the rotational stiffness requirement $K_{\varphi}$ to be calculated using the formula from $\S$ 4.6.3.2.2 and applying the requirement from $\S 3.5 .5$.

\section{6)}

\section{Construction measures}

Current regulations (CFMS Stone-Column Recommendations [2011]) and those of paragraph 5.1.2 apply, and are completed below.

\section{6.}

\section{Containing columns}

The mobilizable load in stone columns is limited by the mobilizable lateral earth pressure in surrounding ground (according to the limit pressure or CPT tip resistance, see chapter 5.4.12 of "CFMS Stone-Column Recommendations [2011])".

Wind-turbine foundation slabs generate significant specific stresses at the foundation edges.

If the calculation methods used to design stone columns assume a perfect column confinement and an infinite mesh, the number of peripheral stone columns under the foundation slab must be increased, or an additionnal row of peripheral columns must be installed to allow for this containment.

In addition, containing columns must be planned outside the footing in the following cases:

- When the foundation design takes account of improvements of soil characteristics located between the columns (especially for the lateral earth pressure) as a result of their installation method (ground tightening);

- In this case, acceptance tests between columns (CPT, PMT, etc.) must be carried out to confirm these improvements;

- In the case of liquefiable soil, where stone columns have an anti-liquefaction function;

- The treatment must then be extended to an extended width equal to half the bottom depth of the layer prone to liquefaction.

\subsection{5.}

\section{Load-transfer platform}

In addition to paragraph 4.2 of the "CFMS StoneColumn Recommendations", load transfer (especially shear strength) in the specific case of wind turbines must be obtained by means of a load-transfer platform on the underside of the foundation slab.

The aim of this platform is avoid any disturbance and ensure homogenous contact between the footing and soil.

Comment: If the stone columns are made at the bottom of the excavation on a work platform made of natural gravel, this work platform can be integrated into the load-transfer platform. If the stone columns are made on natural ground before excavation, it is advisable to lay a load-transfer platform between the columns and foundation underside.

The load-transfer platform with a height $\mathrm{H}_{\text {plat }}$ must be installed in accordance with "sub-grade layer" or "road" requirements (LCPC/SETRA 2000a and b), whether it is made of frictional material (natural gravel) and/or treated with binders (cement, lime, etc.).

It is characterized by in-situ "sub-grade layer" or "road" tests (plate loading tests, etc.), or by more standard geotechnical tests (such as pressuremeter or penetrometer tests), or laboratory tests (CBR or Immediate Bearing Index, cohesion measurements, friction angle, water content, etc.).

The aim of these tests is to check the in situ compactness of the material and determine its constitutive behavior by estimating its various deformation moduli (pressuremeter modulus if possible, Young's modulus E, or oedometric modulus Eoed) and shear strength $\left(c^{\prime}, \varphi^{\prime}\right)$. This is in order to calculate the settlement, ultimate compressive strength and shear resistance of the material in this layer.

The geomechanical characteristics of this loadtransfer platform, for example EV2 modulus and its thickness, will vary according to the foundation system. design. This load-transfer platform generally consists of at least $40 \mathrm{~cm}$ of material:

- Natural gravel granular backfill;

- For example, class D1, D2 or D3, or R in accordance with LCPC/SETRA (2000a and b) (or NFP 11-300),

- Compacted to $95 \%$ of the Modified Proctor Optimum (OPM),

- Which gives a deformation modulus (equivalent to an EV2 modulus) of around $50 \mathrm{MPa}$, an EV2/EV1 ratio $<2.1$ and a friction angle of $40^{\circ}$ for crushed aggregate and $38^{\circ}$ for rolled aggregate;

- Soil treated with binder, whose ordinary cohesion characteristics and friction angle to be taken into account for the calculations are at least $\mathrm{c}^{\prime}=50 \mathrm{kPa}$ and $\varphi^{\prime}=25^{\circ}$.

The load-transfer platform is to be installed according to professional practices and is subject to the standard inspections for accepting sub-grade layers beneath ground slabs.

To distribute the concentration of foundation-slab peripheral stresses as well as possible, there must be a load-transfer platform extended over a width corresponding to at least the maximum of $\left(\mathrm{H}_{\mathrm{plat}} / 2\right.$; $0.5 \mathrm{~m}$ ) beyond the edge of the foundation slab and last row of columns. This is the minimum width to ensure satisfactory compaction.

Construction measures to ensure that the load-transfer platform is not contaminated by the supporting soil are to be implemented (geotextile, anticontamination layer, etc.).

\section{5}

\section{Verification and Inspection}

These are to comply with those in chapter 6 of the "CFMS Stone-Column Recommendations (2011)" and are completed by the following recommendations. 


\section{4he}

\section{Bearing and weathering of the excavation top}

Please refer to chapter 5.1.3.

\section{2}

\section{Load-transfer platform}

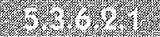

Thickness

Load-transfer platform thickness is verified by comparing topographic readings at three different points per wind turbine.

\section{6)}

Quality

"Sub-grade layer", plate loading, CBR or Immediate Bearing Capacity test, as well as $\varphi^{\prime}$ and particle-size measurements are recommended.

Comment: For an embankment thicker than $1 \mathrm{~m}$, pressuremeter or CPT tests can be used.

The frequency of these various types of test can be as follows:

- Bearing tests (a choice of plate loading, $\mathrm{q}_{\mathrm{c}^{\prime}} \mathrm{p}_{1}$ or CBR);

- At least 3 per foundation slab and 3 per construction site;

- Identification (particle size) and/or characterization tests $\left(c^{\prime}, \varphi^{\prime}\right)$;

- At least 1 per construction site.

\section{4}

\section{Gravity bases on soil reinforced with rigid inclusions}

The recommendations in this chapter 5.4 are an addition to those of the National ASIRI (Amélioration des Sols par Inclusions RIgides) Project and contractor specifications, and take account of the specific character of wind-turbine foundations.

\section{6.t.}

\section{Description}

A wind-turbine foundation slab is generally polygon-shaped and is similar to a circular slab with the same surface area and diameter $\boldsymbol{\Phi}$. Its base is usually horizontal and is at depth $\mathrm{h}$ from the surface level. The footings are considered to be infinitely rigid.

The foundation slab is supported by soil improved using a group of $n$ rigid inclusions (RI) with a diameter $\Phi_{1}$ and a length $\mathrm{L}$.

Chapter 5.4 applies exclusively to soil reinforcement using the technique of vertical rigid inclusions under wind-turbine foundation slabs. This type of soil reinforcement involves installing a group of vertical rigid inclusions that pass through the compressible soil. This is to improve and homogenize soil conditions under the foundation by creating composite material;
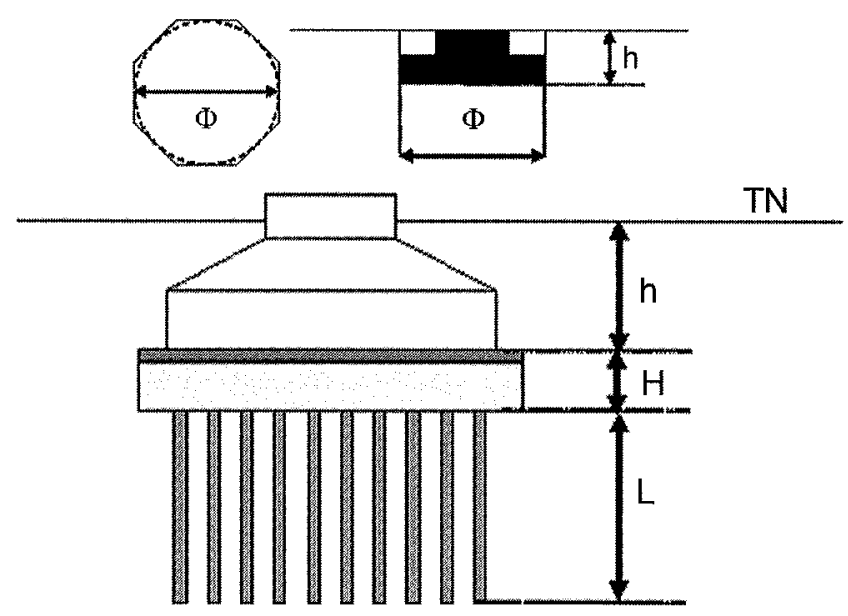

4co 10 . Reinforcement diagram.

- These inclusions can be installed using a wide variety of techniques (drilling, boring, vibration, soil displacement, etc.);

- These inclusions are usually made of concrete, mortar, or metal.

Load transfer from the foundation slab therefore must be via a load-transfer platform laid between the foundation base and the inclusion heads. If this is not possible, the procedures for hybrid or "composite" foundations are applied (see chapter 5.6).

The design parameters for soil reinforcement are therefore as follows:

- Inclusion depth L;

- Inclusion cross-section area and/or its equivalent diameter $\Phi_{1}$;

- Inclusion material strength, its deformation characteristics (modulus of deformation, Poisson's ratio, etc.);

- Inclusion bearing requirements in relation to the soil;

- Number of inclusions, their mesh, or the incorporation ratio $\alpha$ of reinforcements, which represents the ratio of area covered by the inclusion heads and total treated surface area;

- Load-transfer platform characteristics:

- thickness $\mathrm{H}_{\text {plat }}$

- intrinsic characteristics: $\mathrm{c}^{\prime}$ and $\varphi^{\prime}$,

- the modulus of deformation $E$ and shear modulus $G$,

- compactness.

\section{S.}

\section{Area of use}

This soil reinforcement system is the preferred choice in areas 1 and 2, with the comments made in paragraph 5.1 taken into account.

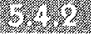

\section{Geotechnical Data}

To justify the bearing and calculate settlement and rotation of the foundation slab on reinforced soil, it is important to remember that the geotechnical data should combine: 
- The requirements in chapter 5.1.2 for gravity bases; - Specific requirements for calculating rigid inclusion bearing, namely including knowledge of the soil over a height equal to $\mathrm{h}+\mathrm{H}+\mathrm{L}+\operatorname{maximum}\left(5 \mathrm{~m} ; 7 \varnothing_{1} ; \varnothing / 2\right)$.

Successive geotechnical studies must enable a standard cross-section to be specified, with all of the soil parameters listed in $\$ 4.6 .1$ and 4.6 .2 per approximately homogeneous layer.

\subsection{5}

\section{Rigid-Inclusion Operation}

\section{Ua}

\section{Vertical structural stresses}

The following assumptions are made:

- The structure's load is distributed between the soil and rigid inclusions:

- by stresses diffusing through the load-transfer platform,

- by "soil-inclusion" and "inclusion-soil" load transfer under the effect of relative displacement of the inclusions and the surrounding soil due to their differential shortening (elastic behavior);

- Loading of rigid inclusions is limited by the effect of their settlement on the sub-base layer under the inclusion tip and by the inclusion penetrating into the load-transfer platform (elastoplastic behavior of "inclusion-load-transfer platform" and "inclusionanchoring" contact).

\section{1.}

\section{Non-vertical structural stresses}

Rigid inclusions are not designed to directly take up horizontal stresses, moments or heaving stress from the structure.

Specific measures must therefore be adopted to take up these stresses. Standard design methods for shallow footings (friction, ballasting, etc.) can be used for this.

Depending on their intrinsic characteristics and soil conditions, inclusions can tolerate low parasitic stress values (horizontal stresses, shear, etc.) that must be estimated. It is therefore advisable to verify how compatible these stress values are with the strength requirements for inclusion materials (see $§ 5.4 .4$ ).

\section{5.}

\section{The aim of soil reinforcement}

Soil reinforcement aims to provide reinforced soil with the mechanical characteristics required for constructing a wind turbine on a standard-weight foundation slab. The foundation must behave as on a homogenous soil.

The following parameters must therefore be determined to design the foundation slab:

- Those for calculating SLS/ULS bearing capacity of reinforced soil;

- $K_{v}$ and $K_{4}$ foundation reaction coefficients, or equivalent $\mathrm{ST}$ and $\mathrm{LT}$ deformation moduli $\mathrm{E}_{\mathrm{eq}}$ for reinforced soil;
- Those enabling slide verification, especially the friction angle:

- Equal to the load-transfer platform friction angle, for verifying horizontal sliding under the footing,

- Equal to the soil friction angle, for verifying horizontal sliding on the underside of the loadtransfer platform;

- Equivalent Poisson's ratio $v_{\text {eq }}$ for reinforced soil;

- Equivalent dynamic shear modulus $G_{\text {dyneq for }}$ reinforced soil in the deformation range of $10^{-3}$ to $10^{-4}$ and the dynamic rotational stiffness ratio $\mathrm{K}_{\text {cpdyn }}$ for the foundations on reinforced soil.

The construction, design and supervision of rigid inclusions not defined in Fascicle 62-Title $V$ must be covered and validated by the ASIRI recommendations, or by specifications that are specific to the contractor's construction method [in accordance with DTU 13.2 $\S 1.11$ ( + comments)].

Rigid inclusions are soil reinforcement procedures: they are not foundation components or deep foundations. The design regulations for foundation piles or granular inclusions do not apply to soil reinforced with rigid inclusions.

\section{Whis}

\section{Inclusion justification}

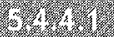

\section{Verifying reinforced soil bearing}

When the design calculations are carried out, the distribution of stresses between the soil and the inclusions must be verified to ensure that soil-inclusion interaction limits are not exceeded. This must be verified for all rigid inclusions, including between the load-transfer platform and rigid inclusions.

Nevertheless, partial excess of some of these interaction limits values is allowed, subject to verification of the overall and local bearing capacity.
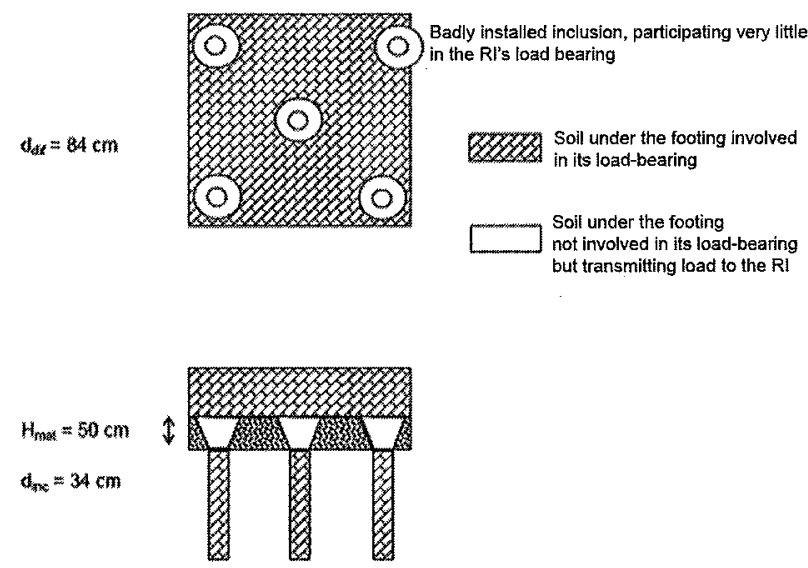

Fe. 11. Example of rigid-inclusion distribution under a footing.

In all cases of SLS or ULS, $\mathrm{S}_{\text {comp }}, \sigma_{\max } \sigma_{\min }$ and $q_{\text {ref }}$ $=\left(3 \sigma_{\max }+\sigma_{\min }\right) / 4$ are calculated in accordance with paragraph 3.5 .2 
Comment: For a column to be taken into account in the overall bearing calculation, its presence in the entirely compressed imaginary soil section must be verified, as set out in $\$ 3.5 .2$ and illustrated in Appendix $B$.

To take account of the specific character of windturbine foundations, the local and overall bearing requirements described in the following paragraphs must be verified for all load cases by pressuremeter and penetrometer methods.

\section{3) 4 (t)}

Overall Bearing Requirement

The following overall bearing requirement is verified for all cases of SLS and ULS loads, with:

$$
\begin{aligned}
& q_{\text {soilSLS }}>\left(q_{\text {refSLS }} S_{\text {ref }}-n Q_{\text {colsLS }}\right) /\left(S_{\text {ref }}-n A_{p}\right) \\
& q_{\text {soilULS }}>\left(q_{\text {refULS }} S_{\text {ref }}-n Q_{\text {colULS }}\right) /\left(S_{\text {ref }}-n A_{p}\right)
\end{aligned}
$$

$\mathrm{n}=$ number of inclusions under the reference surface area $S_{\text {ref }}$ illustrated in Appendix $B$

$$
\begin{gathered}
\mathrm{Q}_{\text {colsLS }}=A_{p} \min \left[0.3 f_{c}{ }^{*} ;\left(R_{b} / \gamma_{b}+R_{s} / \gamma_{s}\right) / A_{p}\right] \\
Q_{\text {colULS }}=A_{p} \min \left[\alpha_{c c} f_{c}^{*} / 1.5 ;\left(R_{b} / \gamma_{b}+R_{s} / \gamma_{s}\right) / A_{p}\right]
\end{gathered}
$$

$\alpha_{c c}=0.8$ for unreinforced inclusions, 1 in other cases.

With pressuremeter or penetrometer methods, the following are used respectively

$$
\mathrm{q}_{\text {soilsLS }}=\mathrm{k}_{\mathrm{p}} \mathrm{p}_{\mathrm{le}} / \gamma_{\text {soilsLS }}+\mathrm{q}_{\mathrm{o}}^{\prime} \text { or } \mathrm{q}_{\text {soiluLS }}=\mathrm{k}_{\mathrm{c}} \mathrm{q}_{\text {ce }} / \gamma_{\text {soiluLS }}+\mathrm{q}_{\mathrm{o}}^{\prime}
$$

\begin{tabular}{|c|c|c|c|c|c|}
\hline \multirow[t]{2}{*}{ QP SLS } & Driven RI & 2.00 & 2.00 & & 3.00 \\
\hline & Bored RI & 2.80 & 2.00 & & 3.00 \\
\hline \multirow[t]{2}{*}{ Rare SLS } & Driven RI & 1.57 & 1.57 & & 3.00 \\
\hline & Bored RI & 2.20 & 1.57 & & 3.00 \\
\hline ULS & & 1.40 & 1.40 & 1.75 & 2.00 \\
\hline
\end{tabular}$$
\mathrm{q}_{\text {soilsLS }}=\mathrm{k}_{\mathrm{p}} \mathrm{p}_{\mathrm{le}} / \gamma_{\text {soilsLS }}+\mathrm{q}_{\mathrm{o}}^{\prime} \text { or } \mathrm{q}_{\text {soilsLS }}=\mathrm{k}_{\mathrm{c}} \mathrm{q}_{\mathrm{ce}} / \gamma_{\text {soilsLS }}+\mathrm{q}_{\mathrm{o}}^{\prime}
$$

For the overall bearing requirement, the coefficients chosen to apply the formulae are as follows:

Additional Information: During verification of the system's overall bearing capacity by applying the above safety factors, the ultimate values for some of the resisting components (soil under the footing, load-transfer platform, inclusion friction and inclusion tip) may be attained but not exceeded (partial safety factor of 1 when in operation) when the calculations for stress distribution between the soil, load-transfer platform and inclusions are carried out.

\section{1.}

\section{Local Bearing Requirement}

The following must be verified for all load cases (SLS and ULS), mesh by mesh.

The following local bearing requirement is verified with:

$$
\begin{gathered}
\mathrm{q}_{\text {soilsLS }}>\left(\mathrm{q}_{\text {refULS }} \mathrm{S}_{\text {mesh }}-\mathrm{Q}_{\text {colULS }}\right) /\left(\mathrm{S}_{\text {mesh }}-\mathrm{A}_{\mathrm{p}}\right) \\
\mathrm{q}_{\text {soiluLS }}>\left(\mathrm{q}_{\text {refSLS }} \mathrm{S}_{\text {mesh }}-\mathrm{Q}_{\text {colsLS }}\right) /\left(\mathrm{S}_{\text {mesh }}-\mathrm{A}_{\mathrm{p}}\right) \\
\mathrm{Q}_{\text {colSLS }}=\mathrm{A}_{\mathrm{p}} \min \left[0.3 \mathrm{f}_{\mathrm{c}}^{*} ; \max \left(\mathrm{S}_{\mathrm{d}^{\prime}} \mathrm{A}_{\mathrm{p}}\right) / \mathrm{A}_{\mathrm{p}} \sigma_{\text {plat }}^{\prime} / \gamma_{\text {plat }} ;\right. \\
\left(\mathrm{R}_{\mathrm{b}} / \gamma_{\mathrm{b}}+\mathrm{R}_{\mathrm{s}} / \gamma_{\mathrm{s}} / \mathrm{A}_{\mathrm{p}}\right] \\
\mathrm{Q}_{\text {colULS }}=\mathrm{A}_{\mathrm{p}} \min \left[\alpha_{\mathrm{cc}} \mathrm{f}_{\mathrm{c}}^{*} / 1.5 ; \max \left(\mathrm{S}_{\mathrm{d}} ; \mathrm{A}_{\mathrm{p}}\right) / \mathrm{A}_{\mathrm{p}} \sigma_{\text {plat }}^{\prime} / \gamma_{\text {plat }} ;\right. \\
\left.\left(\mathrm{R}_{\mathrm{b}} / \gamma_{\mathrm{b}}+\mathrm{R}_{\mathrm{s}} / \gamma_{\mathrm{s}}\right) / \mathrm{A}_{\mathrm{p}}\right]
\end{gathered}
$$

Comment: Remember that the imaginary column bearing $\left(Q_{c o l}=q_{c o l} . S_{c o}\right)$ equals the minimum inclusion bearing value in terms of material strength, the inclusion bearing in relation to soil assessed under the neutral point and the embankment column bearing above the inclusion in terms of punching effect:

$\sigma_{\text {plat }}^{\prime}$ and $\gamma_{\text {plat }}$ defined in paragraph 5.4 .5 with pressuremeter or penetrometer methods, the following are used respectively:

$$
\begin{gathered}
\mathrm{q}_{\text {soilsLS }}=\mathrm{k}_{\mathrm{p}} \mathrm{p}_{\mathrm{le}} / \gamma_{\text {soilSLS }}+\mathrm{q}_{\circ}^{\prime} \text { or } \mathrm{q}_{\text {soiluLS }}= \\
\mathrm{k}_{\mathrm{c}} \mathrm{q}_{\mathrm{ce}} / \gamma_{\text {soiluLS }}+\mathrm{q}_{\mathrm{o}^{\prime}}^{\prime} \\
\mathrm{q}_{\text {soilsLS }}=\mathrm{k}_{\mathrm{p}} \mathrm{p}_{\mathrm{le}} / \gamma_{\text {soilsLS }}+\mathrm{q}_{\mathrm{o}}^{\prime} \text { or } \mathrm{q}_{\text {soilsLS }}= \\
\mathrm{k}_{\mathrm{c}} \mathrm{q}_{\mathrm{ce}} / \gamma_{\text {soilsLS }}+\mathrm{q}_{\mathrm{o}}^{\prime} .
\end{gathered}
$$

The safety factors are those given in Table 8.

\section{3.}

\section{Calculating Deformations}

The foundation's settlement and rotation are calculated from the equivalent characteristics of the reinforced soil for short- and long-term loads, according to the principles set out in paragraph 5.2.3.

It is advisable to take account of significant variations in these equivalent characteristics according to mesh-position, as well as differences in geotechnical conditions and applied loads.

\section{3.}

\section{Verification in Compression}

The intrinsic behavior of rigid inclusions is characterized by:

- Young's modulus $\mathrm{E}_{\mathrm{y}}$ for the rigid component's material, for long - and short-term applied loads;

- The compressive strength $\mathrm{f}_{\mathrm{cj}}$ of the rigid component's material, which for concrete inclusions is tested by compressive strength tests;

- The material grade, quality and elastic limit $f_{s}$ in the case of metal inclusions.

\section{1.}

Mortar, grout or concrete inclusions

- Definition of $\mathrm{f}_{\mathrm{cd}}$

If concrete or grout is used, the characteristic design value $f_{c c}$ of the material is defined according to the National Implementation Standard of Eurocode 7 (NF P94 262 Deep Foundations) or special specifications:

$$
f_{c d}=\operatorname{Min}\left(\alpha_{c c} k_{3} \frac{f_{c k}^{*}}{\gamma_{C}} ; \alpha_{c c} \frac{f_{c k}(t)}{\gamma_{C}} ; \alpha_{c c} \frac{C_{\max }}{\gamma_{C}}\right)
$$

with:

$\alpha_{c c}$ coefficient depends on the presence or absence of a reinforcement (if reinforcement is present $=1$, without reinforcement $=0.8$ );

$\gamma_{C}$ partial factor with a value of 1.5 at fundamental ULS and 1.2 at accidental ULS;

$\mathrm{f}_{\mathrm{ck}}{ }^{*}$ characteristic value of the compressive strength of the concrete, grout or mortar in the inclusion, determined using the following formula:

$$
f_{c k}^{*}=\inf \left(f_{c k}(t) ; C_{m a x} ; f_{c k}\right) \frac{1}{k_{1} k_{2}}
$$


$\mathrm{f}_{\mathrm{ck}}$ characteristic concrete strength under compression, measured on cylinders at 28 days;

$f_{c k} \quad(t)$ characteristic concrete strength under compression, measured on cylinders at time t;

$\mathrm{k}_{1}$ and $\mathrm{k}_{2}$ according to boring method and slenderness;

$\mathrm{k}_{3}$ according to type of structure for more thorough inspection or additional in-situ test procedures;

$\mathrm{C}_{\max }$ takes account of the required consistency for fresh concrete, grout or mortar.

- Definition of $\mathrm{k}_{3}$

The $k_{3}$ value is defined in the following table, according to test type, foundation type and number of inclusions under this foundation.

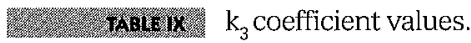

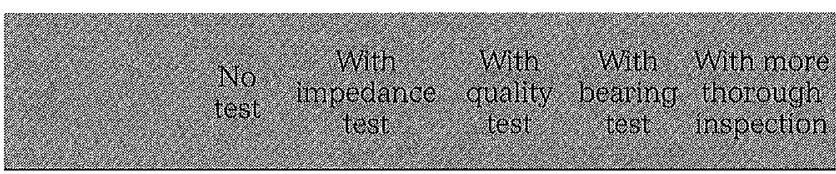

Area 1:

\begin{tabular}{|c|c|c|c|c|c|}
\hline $\begin{array}{l}\text { (inclusions } \\
\text { required } \\
\text { for stability) }\end{array}$ & 1.0 & 1.1 & 1.15 & 1.2 & 1.2 \\
\hline $\begin{array}{c}\text { Area 2: } \\
\text { (inclusions } \\
\text { not required } \\
\text { for stability) }\end{array}$ & 1.0 & 1.3 & 1.4 & 1.5 & 1.5 \\
\hline
\end{tabular}

Quality tests at the allowable service load; bearing capacity test at 1.5 times the allowable service load with creep increments; more thorough inspection as per the DTU (French building regulations) 13.2. The allowable load is defined as the load giving maximum stress at SLS. The columns tested may or may not form part of the structure.

- Bearing capacity at SLS and ULS

The maximum compressive force at ULS is limited to the design value $\mathrm{f}_{\mathrm{cd}}$. The mean compressive force on the only compressed section is limited to $7 \mathrm{MPa}$.

The maximum compressive force of concrete at SLS is limited to $0.6 \mathrm{f}_{\mathrm{c}}^{*}$ and the mean compressive force on its only compressed section is limited to a minimum $\left(0.3 \mathrm{f}_{c}\right.$; $\left.0.45 \mathrm{f}_{\mathrm{c}}\right)$.

Comment: For mortar (fc $\leq 15 \mathrm{MPa}$ ) or soil concrete (jet-grouting, soil mixing, etc.) rigid inclusions, $f_{c i}$ is calculated according to the compressive test results), with lower cement and binder doses than prescribed by standards for concrete. The mean stress on the compressed section is obtained using coefficients $k_{1}, k_{2}$ and $k_{3}$ and is limited to $5 \mathrm{MPa}$ at SLS; the maximum stress in combined bending is limited to $10 \mathrm{MPa}$ at ULS.

\subsubsection{5.}

\section{Metal inclusions}

For metals, the material's grades and quality are those specified in NF EN 10025.

Comment: The sacrificial thicknesses due to corrosion must be taken into account (See Fascicle 62 - Title $V$ [MELT, 1993]].

\section{1.:5}

\section{Verification in combined bending and in shear}

\section{5.t. Wh}

\section{Transmission of Horizontal Stresses}

It is advisable to design the load-transfer platform so that transmission of horizontal stresses to rigid inclusions is limited as much as possible (horizontal stress, shear, etc.). The intensity of these stresses must be evaluated, as well as the consequences on rigid inclusions regarding the maximum and minimum stresses in inclusion material.

The aim of the calculation is to verify that stresses in the rigid inclusions are acceptable, by considering both:

- Vertical stress;

- Horizontal stress applied in the inclusion head;

- Soil displacement under the horizontal stress applied by the foundations.

The following simplified method is suggested, and provides an order of magnitude of the expected results.

- Simplified method

Shear stresses at the underside of the footing are distributed according to the friction under the footing and thus in proportion to the distribution of vertical stresses under compression:

- $\sigma_{i}$ and $\tau_{\mathrm{RI}}$ respectively in the imaginary column surmounting the rigid inclusion through the loadtransfer platform;

- and $\sigma_{\mathrm{s}}$ and $\tau_{\mathrm{s}}$ outside this imaginary column.

The shear stresses therefore only apply on soils or imaginary columns under compression, especially in the case of overturning moments applied to the footing.

In the case of footings subject to a set of efforts $(Q$, $\mathrm{M}, \mathrm{H}$ ), each column subject to compression has a value $Q_{i}$ and thus takes up a shear force $h_{i}$ in the head of the imaginary column such that:

$$
\begin{gathered}
h_{\mathrm{i}}=H \mathrm{Q}_{\mathrm{i}} / \mathrm{Q} \\
\mathrm{h}_{\mathrm{s}}=\mathrm{HQ}_{\mathrm{sem}} / \mathrm{Q} \\
\text { with } \mathrm{Q}= \\
\mathrm{Q}_{\text {sem }}+\Sigma \mathrm{Q}_{\mathrm{i}^{\prime}} \text { with } \mathrm{H}=\mathrm{h}_{\mathrm{s}}+\Sigma \mathrm{h}_{\mathrm{i}}
\end{gathered}
$$

According to the load-transfer platform's thickness, horizontal stresses in the imaginary column reduce with depth.

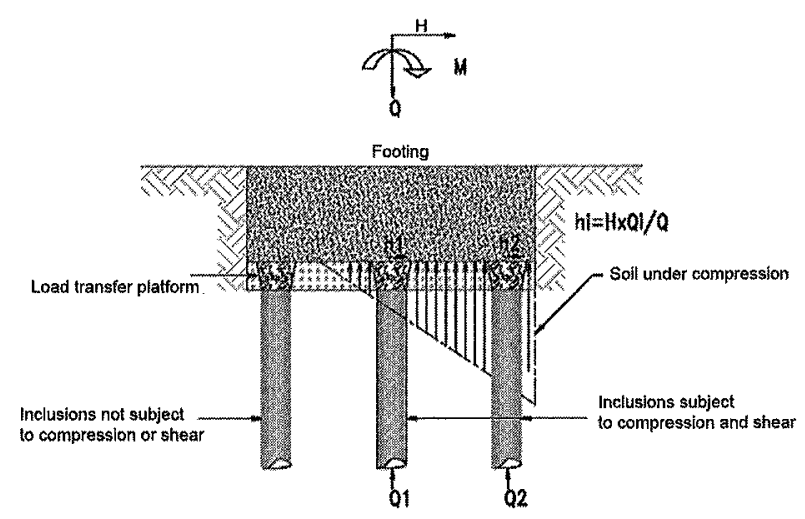

月6. 1 (1) Load-distribution diagram. 
Initially, this reduction may be ignored and shear force $h_{i}$ and bending moment $M_{i}$ induced in the rigid section of the rigid inclusion may be calculated according to the elastoplastic reaction model:

$$
\begin{gathered}
h_{i}=\tau_{i} A_{p} \text { where } A_{p} \\
\text { is the surface area of the rigid inclusion } \\
M_{i}=0.32 l_{o} h_{i} \text { where } l_{0} \\
\text { is the transfer length }
\end{gathered}
$$

and design the necessary reinforcements according to $M_{i} / Q_{i}$ and $h_{i}$.

Comment: Note that this simplified method is conservative since it does not take account of stress diffusion through the load-transfer platform and hence only enables us to give a maximum value for horizontal stresses that may be transmitted to the inclusions.

- Finite element methods

To obtain a more accurate picture of these stresses, a more sophisticated approach with finite element (or finite differences) can be used, which enables:

- Either complete 3D-modeling, with rigid inclusions, load-transfer platform, foundation footing and their interfaces by applying the total torque $(\mathrm{Q}, \mathrm{H}, \mathrm{M})$;

- Or simpler modeling:

Step1: the equivalent characteristics of reinforced soil around a representative rigid inclusion (concentric soil cylinder around the rigid inclusion, for an average mesh) are calculated using an axisymmetric model, as well as the distribution of compressive forces between the soil and rigid inclusion.

Step 2: a 3D-calculation is performed after replacing the reinforced soil with rigid inclusion by this equivalent homogeneous soil and by applying the total torque $(\mathrm{Q}$, $\mathrm{H}, \mathrm{M})$.

Step 3: the rotation and maximum settlement of the footing, as well as the geometry of the completely compressed soil surface under the footing are then deduced. This is to locate the rigid inclusions under compression and the compressive and shear forces acting on the least favorable mesh (with a surface area $\mathrm{S}_{\mathrm{m}}$ ) at the base of load-transfer platform.

Step 4: the vertical load $\left(S_{m} \times\right.$ mean compressive stress) acting on this mesh is distributed according to the schema in step 1 , and $Q_{i}$ is defined.

Step 5: the horizontal load is distributed in proportion to the compressions.

Note: In particular, these finite element methods enable the diffusion of shear forces through the loadtransfer platform to be taken into account.

Comment: A pre-design analysis using analytical calculation must be carried out before these finite element methods.

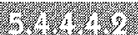

Verification in combined bending and in shear

For each inclusion under compression, shear force $V_{i}$ and force eccentricity $M_{i} / Q_{i}$ are then verified to determine whether reinforcement of concrete is necessary (for concrete inclusions), according to $V_{i}$ and $\mathrm{M}_{\mathrm{i}} / \mathrm{Q}_{\mathrm{i}}$.

\section{- Combined bending}

The extreme normal stresses in the rigid inclusions used in combined bending (axial stress $\mathrm{N}$ and bending moment $\mathrm{M}$ ) are then given by the following formula:

$$
\sigma=\frac{N}{S} \pm \frac{M}{I / v}
$$

Where for a completely compressed surface:

$$
S=\pi \frac{B^{2}}{4} ; I=\pi \frac{B^{4}}{64} ; v=\frac{B}{2}
$$

- Shear at ULS

Shear stresses in rigid inclusions induced by shear forces are then given by the following formulae, according to the maximum shear force $V_{i}$.

Without reinforcements and for a completely compressed section.

For unreinforced inclusions, the shear stress at ULS must be verified in accordance with Eurocode 2, Part 12 , reduced to the diameter in accordance with the following equations:

$$
\begin{gathered}
\tau_{c p}=1.91 \mathrm{~V}_{\mathrm{i}} / \mathrm{B}^{2} \\
\tau_{\mathrm{cp}}<\mathrm{f}_{\mathrm{cvd}} \\
\sigma_{\mathrm{clim}}=\mathrm{f}_{\mathrm{cd}}-2\left[\mathrm{f}_{\mathrm{ctd}}\left(\mathrm{f}_{\mathrm{ctd}}+\mathrm{f}_{\mathrm{cd}}\right)\right]^{0.5} \\
\sigma_{\mathrm{cp}}=\mathrm{Q}_{\mathrm{i}} / \mathrm{S}_{\mathrm{col}}
\end{gathered}
$$

$\mathrm{S}_{\text {col }}=$ compressed column section

$$
\begin{gathered}
\mathrm{f}_{\mathrm{ctm}}=0.3\left[\mathrm{f}_{\mathrm{ck}}\right]^{(2 / 3)} \\
\mathrm{f}_{\mathrm{ctk} 0.05}=0.7 \mathrm{f}_{\mathrm{ctm}} \\
\mathrm{f}_{\mathrm{ctd}}=\alpha_{\mathrm{cpl}} \mathrm{f}_{\mathrm{ctk} 0.05} / 1.5 \text { with } \alpha_{\mathrm{cpl}}=0.8
\end{gathered}
$$

$\mathrm{f}_{\mathrm{cd}}=$ design strength under compression

and by writing $f_{c k}=f_{c}^{*}$ we obtain:

$$
f_{c d}=\min \left(0.8 f_{c}^{*} / 1.5 ; 0.8 f_{c} / 1.5\right)
$$

$\mathrm{f}_{\mathrm{cyd}}=$ design strength in compressed shear

$$
\begin{gathered}
\text { if } \sigma_{c p}<\sigma_{c l i m} \\
f_{c v d}=\left(f_{c t d}{ }^{2}+\sigma_{c p} f_{c t d}\right) 0.5
\end{gathered}
$$

otherwise: $\mathrm{f}_{\text {cyd }}=\left(\mathrm{f}_{\mathrm{ctd}}{ }^{2}+\sigma_{\mathrm{cp}} \mathrm{f}_{\mathrm{ctd}}-\left[\left(\sigma_{\mathrm{cp}}-\sigma_{\mathrm{clim}}\right) / 2\right]^{2}\right)^{0.5}$

In accordance with the National Appendix of Eurocode 2 and the National Implementation Standard of Eurocode 7 (NF P94-262), no shear is allowed when the diameter is less than $400 \mathrm{~mm}$.

In accordance with the National Implementation Standard of Eurocode 7 (NF P 94-262), when $\mathrm{N}_{\text {ed }}$ exceeds $0.3 f_{c}^{*} A_{p}$ at SLS, the $f_{c v c}$ value is taken to be:

$$
f_{c v d}=0.1\left[\left(f_{c t d}{ }^{2}+\sigma_{c p} \cdot f_{c t d}-\left[\left(\sigma_{c p}-\sigma_{c l i m}\right) / 2\right]^{2}\right)^{0.5}\right]
$$

The table in Appendix $\mathrm{E}$ gives the corresponding values according to the material's compressive strength.

If reinforcements are present

Verify that $\mathrm{V}_{\mathrm{i}}<\mathrm{V}_{\mathrm{Rd}, \mathrm{S}}$ and that $\mathrm{V}_{\mathrm{i}}<\mathrm{V}_{\mathrm{Rd} \text {,max }}$ at ULS.

The reinforcements to be installed are calculated as follows:

$$
V_{\mathrm{R} d, S}=\frac{A_{s w} z / 4_{s t}^{f}}{y w d}(\cot \theta+\cot \alpha) \sin \alpha
$$

Where $s_{t}$ is the coil spacing, $\alpha$ the hoop incline, $\mathrm{f}_{\text {rwd }}$ the steel strength $\left(=\mathrm{f}_{\mathrm{e}} / \gamma_{\mathrm{s}}\right)$, and where $\cot \theta \operatorname{can}$ be between 1 and 2.5 .

Comment: These recommendations stipulate that $\alpha=90^{\circ}$ and $\theta=45^{\circ}$.

The maximum ULS shear force taken up by the concrete is calculated as follows, using the following formula:

$$
V_{R d, \max }=\alpha_{c w^{\prime}}\left(b_{W z} / 1.4\right)_{V 1 f_{c d}}(\cot \theta+\cot \alpha) /\left(1+\cot ^{2} \theta\right)(66)
$$

Where $\mathrm{z}$ is the lever $\operatorname{arm}(\mathrm{z}=7(\Phi-\mathrm{e}) / 8)$; $\mathrm{b}_{\mathrm{w}}=\Phi ; \alpha_{\mathrm{cw}}=1$. 


\subsection{1.}

\section{Load-transfer platform}

Load transfer from the foundation slab occurs via a load-transfer platform. This platform must be laid between the foundations and inclusion heads.

This platform also has a diffusion effect that helps limit the transmission of horizontal stresses and shear to the inclusions.

The load-transfer platform with a height $\mathrm{H}_{\text {mat }}$ must be installed according to "sub-grade layer" or "road" requirements (LCPC/SETRA 2000a and b), whether they consist of frictional materials (natural gravel) and/ or are treated with binders (cement, lime, etc.).

It is characterized using in-situ "road" or "sub-grade layer" tests (plate load tests, etc.), or more standard geotechnical tests (pressuremeter or penetrometer tests), or laboratory tests (CBR or Immediate Bearing Capacity ratio, cohesion measurements, friction angle and water content, etc.).

The aim of these tests is to verify the in-situ compactness of the materials and determine their constitutive behavior law by estimating their various ordinary moduli of deformation (pressuremeter modulus, if possible, Young's modulus E or oedometric modulus $\mathrm{E}_{\text {oed }}$ ) and shear $\left(\mathrm{c}^{\prime}, \phi^{\prime}\right)$, and calculating the settlement, the ultimate compressive strength and the shear strength of the material in this layer.

Its geomechanical characteristics, for example EV2 modulus and platform thickness, will vary according to the design study for the foundation system. They depend on in-situ soil characteristics, column diameter, spacing and depth, the type and intensity of loads, and the rigidity of the planned structure.

This load-transfer platform generally consists of at least $40 \mathrm{~cm}$ of material:

- Natural gravel granular backfill;

- for example, class D1, D2 or D3 or R in accordance with LCPC/SETRA (200a and b) (or NFP 11-300),

- compacted to $95 \%$ of the Modified Proctor Optimum,

- which gives a deformation modulus (equivalent to an EV2 modulus) of around $50 \mathrm{MPa}$, an EV2/EV1 ratio $<2.1$, and a friction angle of $40^{\circ}$ for crushed aggregate and $38^{\circ}$ for rolled aggregate;

- For soils treated with binder, whose ordinary cohesion characteristics and friction angle to be taken into account for the calculations are at least $\mathrm{c}^{\prime}=50 \mathrm{kPa}$ and $\varphi^{\prime}=25^{\circ}$

The inclusion head stands proud of poor-quality soil and punches through the load-transfer platform. At this level, the behavior of the upper side of the platform is comparable to the behavior of an embedded anchor plate at depth $\mathrm{H}_{\text {th }}$ (platform thickness) and is drawn upwards by a load $\mathrm{Q}_{i}(0)$ (equal to the inclusion head load) when under tension.

This behavior law in the inclusion head depends on the following parameters:

- The platform's deformation characteristics (Young's modulus and Poisson's ratio);

- The material's intrinsic characteristics (cohesion and friction angle);

- The material's confinement state.
Construction measures required to ensure the load-transfer platform is not contaminated by the supporting soil are to be implemented (geotextile, anticontamination layer, etc.)

\section{8.}

\section{Modulus of deformation}

The platform's modulus of deformation may be calculated by correlation with plate loading tests, CBR tests or equivalent, or correlation with in-situ tests (pressuremeter or penetrometer tests):

- Pressuremeter tests are reserved for thicknesses greater than $1 \mathrm{~m}$; the modulus of deformation $E_{y s t}$ is considered to be $\mathrm{E}_{\mathrm{M}} / \alpha / 1.5$ for $v=0.33$;

- Penetrometer tests are reserved for thicknesses greater than $0.8 \mathrm{~m}$; for granular aggregate the correlation $\mathrm{E}_{\mathrm{y}} \approx 6 \mathrm{q}_{\mathrm{c}}$ is used;

-Different tests (plate loading, CBR, Immediate Bearing index) are preferable in other cases; in the case of a plate loading test, we consider that $\mathrm{E}_{\mathrm{y}}=\mathrm{EV} 2$ (natural gravel granular backfill).

\section{14}

\section{Verifying the load-transfer platform}

The failure mechanism is similar to a head punching effect in the platform.

For aggregate treated with hydraulic binders, the failure mechanism may be related to the appearance of a fissure (shear failure or tensile failure).

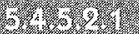

\section{Calculating ultimate compressive strength}

The maximum mobilizable stress in the platform at the inclusion head level can be calculated using the material's failure parameters: cohesion $\mathrm{C}^{\prime}$ and friction angle $\varphi^{\prime}$, according to Prandtl's diagram of failure on the platform layer (Frossard et al., 2002; Berthelot et al., 2006, 2007 and 2011).

The left-hand drawing in Figure 13 describes the distribution of stresses on the underside of the mat foundation. The right-hand drawing shows a simplified distribution of stresses $q_{1}$ and $q_{2}$ on the underside of the load-transfer platform.

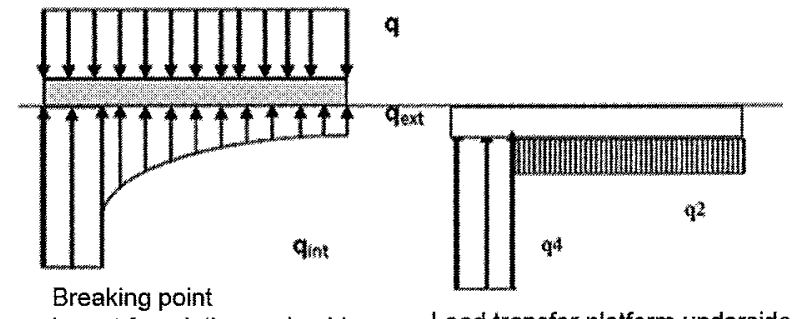

in mat foundation underside

Load transfer platform underside

16. 13 Stress distribution

The diagram for load-transfer platform failure over the inclusion heads can be incorporated into the Prandtl mechanism by combining an equilibrium zone for Rankine active pressure (I) above the inclusion head, a zone delimited by a logarithmic spiral arc (II) and an equilibrium zone for Rankine passive pressure outside the inclusion head (III). 


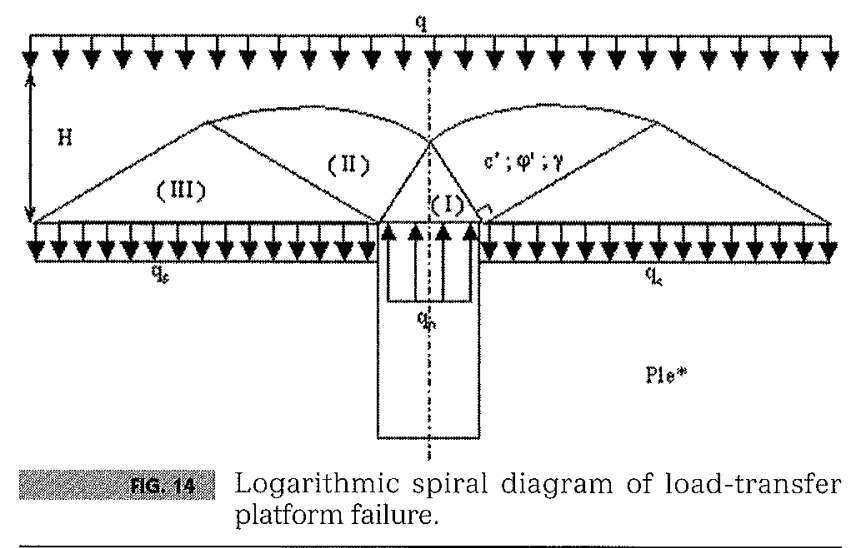

The allowable stress in the inclusion head of the load-transfer platform $q_{\text {plat }}$ is then determined using the stress applied on the soil support $\mathrm{q}_{\text {ext }}$ (limited to $\mathrm{p}_{1} /$ $\gamma_{\text {soil }}$ ) and the load-transfer platform's failure parameters $c^{\prime}$ and $\varphi^{\prime}$ by the following relationship:

Or:

$$
\begin{gathered}
\mathrm{Q}_{\text {piat:SLS }}=\min \left(3 \mathrm{MPa} ; \mathrm{q}_{1 ; \mathrm{SLS}}\right) \text { at SLS } \\
\mathrm{Q}_{\text {plat;ULS }}=\min \left(5 \mathrm{MPa} ; \mathrm{q}_{1 ; \mathrm{ULS}}\right) \text { at ULS }
\end{gathered}
$$

$$
\begin{gathered}
q_{1}=N_{q} \times q_{2}+1.2 \times\left(\frac{C^{\prime}}{\gamma_{c}}\right) \times N_{C} \\
\mathrm{q}_{2}=\min \left(\mathrm{q}_{\text {ext' }} \mathrm{p}_{1} / \gamma_{\text {soil }}\right. \\
N_{q}=\tan ^{2}\left(\pi / 4+\left(\frac{\varphi^{\prime}}{\gamma_{\varphi}}\right) / 2\right) \times e^{\pi \cdot \tan \left(\frac{\varphi^{\prime}}{\gamma_{\varphi}}\right)} \\
N_{c}=\left(N_{q}-1\right) \times \cot \left(\frac{\varphi^{\prime}}{\gamma_{\varphi}}\right)
\end{gathered}
$$

And where the following safety factors are applied:

$$
\begin{gathered}
\gamma_{\text {soil }}=3 \text { at SLS and } 2 \text { at ULS; } \\
\gamma \varphi=1.1 \text { at SLS and ULS; }
\end{gathered}
$$

Example of application: for $40^{\circ}, \mathrm{N}_{\mathrm{q}}(40)=64.2 ; \mathrm{N}_{\mathrm{c}}$ $(40)=75.4$

$\rightarrow \mathrm{N}_{\mathrm{q}}(40 / 1.1)=\mathrm{N}_{\mathrm{q}}(36)=37.8 ; \mathrm{N}_{\mathrm{c}}(40 / 1.1)=\mathrm{N}_{\mathrm{c}}(36)=50.6$ $\mathrm{N}_{\mathrm{q}}$

In other words, a safety factor of $64.2 / 37.8=1.70$ on

$\gamma_{c}=1.25$ at SLS and ULS 1.80

In other words, a safety factor of $1.25 * 75.4 / 50.5=$

Comment: This method can be simplified by retaining a $\gamma_{\text {plat }}$ safety factor $=1.75$.

- Influence of load-transfer platform height

Please refer to the French National ASIRI Project (chapter 4).

- Influence of load-transfer platform extended dimension

Please refer to the French National ASIRI Project (chapter 4).

- Influence of distance between footing edge and outside part of the inclusion

Please refer to the French National ASIRI Project (chapter 4).

\section{5.}

\section{Construction measures}

Current regulations and those of chapter 5.1.2 apply, and are completed in the following chapters.

\section{1.}

\section{Distance between Inclusions}

The minimum distance between inclusion axes must be three times their diameter. Nevertheless, the contractor is responsible for verifying that there is no risk of damage to neighboring columns during construction work. The instructions for their installation are to be changed if necessary.

\section{6 ard 2}

\section{Containing Columns}

The inclusion meshing generally covers the entire surface area of the foundation slab. In principle, provision of confining columns outside the footing is not required.

\section{3}

\section{Load-transfer Platform}

External rigid inclusions are to be installed in a circle, with a maximum diameter of:

$$
\varnothing-\left(h+\varnothing_{1}\right)
$$

\section{5}

\section{Trimming low top levels / work platforms / load- transfer platform}

It is recommended to build columns at a low-level work platform near the foundation base.

Leveling rigid inclusions at the platform level is the best way to ensure homogeneity of the load-transfer platform and a precise concrete top level, thus limiting variations in the load-transfer platform's thickness between inclusion heads and the underside of the mat foundation.

\section{Heving}

Leveling inclusion tops at the work-platform

The work platform can only be recompacted after the inclusions have been installed when at least $25 \mathrm{~cm}$ of sub-grade layer material has been laid. This is to avoid direct compaction over rigid-inclusion heads and their breaking.

\section{3.}

Leveling inclusion tops at the work-platform base

These top levels must be made with a maximum tolerance of $+/-5 \mathrm{~cm}$, to avoid unacceptable local variations in load-transfer platform thickness. The contractor is responsible for ensuring that everything necessary is done to guarantee these tolerances.

It is generally recommended to make these levels using a mini-excavator after drilling machines have been used, while the columns are still "fresh".

The column heads are excavated as far as the platform underside; the mixture containing large quantities of platform material and column mortar is then put back into the platform body before recompaction.

The work platform at this level can be directly recompacted after the inclusions have been installed only if the inclusion top levels are more than $25 \mathrm{~cm}$ beneath the work-platform level. 
For load-transfer platforms treated with binders in-situ above the inclusion heads, the contractor must justify a precise treatment level compatible with the depth tolerance of the earthwork equipment.

Earthworks in the area of non-reinforced rigid inclusions are not permitted: for example, this would be the case for a rigid inclusion work platform higher than the footing underside.

\section{3.}

\section{Verification and inspection}

Current regulations and those of chapter 5.1.2 apply, and are completed in the following chapters.

\section{6.t.}

\section{Inclusion Material}

The sampling frequency is 1 sample per $100 \mathrm{~m}^{3}$ of concrete installed, with a least 1 sample every 3 days and 1 sample per wind turbine (6 specimens per sample).

\section{6.}

\section{Inclusion Continuity}

The continuity of inclusions built is to be verified:

- Either verifying 1 in 8 inclusions;

- with an impedance test,

- or rebound (echo) test;

- Or for all inclusions by recording the boring and concreting parameters.

\section{6.}

\section{Load-transfer platform}

\section{6.i.}

\section{Thickness}

The load-transfer platform thickness is verified by comparing topographic readings at 3 points per wind turbine.

\section{then}

Quality

"Sub-grade" layer, plate loading tests, CBR or Immediate Bearing Capacity ratio tests are recommended, and possibly including $\varphi^{\prime}$ and particlesize measurements.

Comment: For embankments thicker than $80 \mathrm{~cm}$, a pressuremeter test or CPT may be used.

The various tests can be carried out at the following frequencies:

- Bearing tests (a choice between plate loading, $q_{c^{\prime}}$ $\mathrm{p}_{1}$ or $\mathrm{CBR}$ ): at least 3 per foundation slab and 3 per construction site;

- Identification (particle size) and characterization ( $c^{\prime}$, $\left.\varphi^{\prime}\right)$ tests: at least 1 per construction site.

Comment: For good-quality natural gravel as characterized above, characterization tests can be dispensed.

\section{6.}

\section{Work platform/Construction measures}

During and after soil reinforcement, it is advisable to take precautions to avoid inclusion shear (when the inclusions are not reinforced).

Shear risks in the upper section of rigid inclusions may appear in the following cases:

- Heavy construction site equipment moving directly above rigid inclusion heads;

- Taking up the work platform after soil reinforcement by flushing out aggregate.

\section{6}

\section{Pile foundations}

\section{3.}

\section{Description}

A wind-turbine foundation slab is generally polygon-shaped, comparable to a circular slab with the same surface area and diameter $\Phi$. It generally has a horizontal base and is located at depth $\mathrm{h}$ from the platform level. It is supported by $\mathrm{n}$ piles with a diameter $\Phi_{1}$ at a depth $h+\mathrm{L}$, arranged in a circle with a diameter $\Phi_{2}$. rigid.

The foundation slab is considered to be infinitely

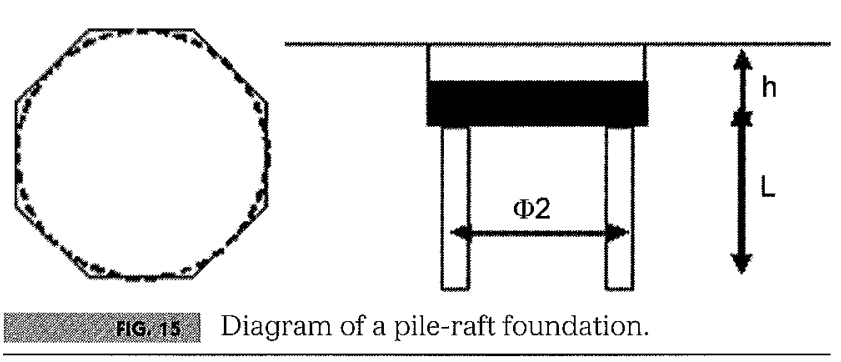

\subsection{9}

\section{Geotechnical data}

Please refer to paragraph 4.6.

\section{thes}

\section{Justifications}

\section{Ther.t.}

\section{Bearing capacity}

Bearing calculations are carried out in accordance with current regulations. No tension is allowed in deep foundations under quasi-permanent ULS loads (due mainly to $\mathrm{DLC}_{\mathrm{QP}}$ load caused by cyclic effects).

\section{Micropiles}

The bearing and aggregate strength calculations are to be carried out in accordance with current regulations. 
A loading test is mandatory: 1 per 50 micropiles and at least 1 per construction site. It is to be carried out in accordance with current regulations.

No tension is allowed in micropiles under quasipermanent ULS (due mainly to DLC ${ }_{\mathrm{QP}}$ load, caused by cyclic effects).

\section{6.}

\section{Settlement and elongation}

\section{5.}

Settlement

Settlement calculations are carried out in accordance with the $\mathrm{t}-\mathrm{z}$ curves method (Frank/Zhao 1982, see Fascicle 62-Title V [MELT, 1993]) in the slab deformation range of $10^{-2}$ to $10^{-3}$.

\section{53.3 .32}

\section{Elongation}

As long as mean tensile stress of the concrete on the tensile section of the pile is greater than $f_{c t} / \gamma_{s^{\prime}}$ the only produced pile ES retained for calculating elongation is that of the steel (value generally around 1.5 MPa).

\section{3.}

\section{Horizontal Stresses}

Horizontal stress calculations are carried out in accordance with current regulations (Appendix E, Fascicle 62-Title V [MELT, 1993]) in the slab deformation range of $10^{-2}$ to $10^{-3}$

Comment: When the foundation slab is not poured directly in the excavation, the soil passive pressure is ignored and the horizontal stresses beneath the underside of the footing equal those applied in the footing head. But when the foundation slab is poured directly into the excavation, the footing passive pressure can be taken into account up to a value validated the geotechnical engineer, subject to the compatibility of deformations based on both footing stop stiffness and horizontal stiffness of the piles. Nevertheless, this value must be limited to $30 \%$ of the maximum passive pressure value.

\section{6}

\section{Overall Rotation}

Rotation is to be calculated according to the moment value, and the vertical and horizontal stiffness of piles.

Remember to take the horizontal soil-pile interaction and group effects between piles into account.

\section{5.}

When the piles are embedded

If the piles are embedded, overall rotation induces $\mathrm{M}_{\mathrm{i}}$ moments in the pile heads, according to:

- Their flexural rigidity (EI);

$\mathrm{EI}$ completely compressed $>\mathrm{EI}$ partially compressed $>\mathrm{EI}$ completely tense - Soil stiffness (in other words, according to $\mathrm{K}_{\mathrm{s}^{\prime}} \Phi$ );
- And hence on the transfer length value $l_{0}$ according to the reaction moduli method).

This reduces the tensile/compressive force applied to the piles.

If the piles are assumed to have the same initial inertia and thus the same head stiffness, namely $\mathrm{K}_{\mathrm{pv}}$ and $\mathrm{K}_{\mathrm{ph}}(\mathrm{MN} / \mathrm{m})$ in the vertical and horizontal planes respectively, the following calculations can be carried out:

$$
\begin{aligned}
& \mathrm{J}=\mathrm{n} \Phi_{2}^{2 / 8} \\
& \mathrm{~J} / \mathrm{V}=\mathrm{J} /\left(\Phi_{2} / 2\right)=\mathrm{n} \Phi_{2} / 4 \\
& \mathrm{Q}_{\max }=\mathrm{M}^{\prime} /(\mathrm{J} / \mathrm{V})=4 \mathrm{M}^{\prime} / \mathrm{n} / \Phi_{2} \\
& \text { With } \mathrm{M}^{\prime}=\mathrm{M}_{\mathrm{xy}}-\mathrm{n} \cdot \mathrm{M}_{\mathrm{i}} \\
& \mathrm{y}_{\max }=\mathrm{Q}_{\max } / \mathrm{K}_{\mathrm{pv}}=4 \mathrm{M}^{\prime} / \mathrm{n} / \Phi_{2} / \mathrm{K}_{\mathrm{pv}} \\
& \varphi=2 \mathrm{y}_{\max } / \Phi_{2}=8 \mathrm{M}^{\prime} / \mathrm{n} / \Phi_{2} / \mathrm{K}_{\mathrm{pv}} / \Phi_{2} \\
& \rightarrow \mathrm{M}^{\prime} / \varphi=\Phi_{2} \mathrm{~K}_{\mathrm{pv}} \Phi_{2} \cdot \mathrm{n} / 8 \\
& \mathrm{M}_{\mathrm{i}}=\varphi \mathrm{K}_{\mathrm{ph}} \Phi_{1} \mathrm{l}_{\mathrm{o}}^{3} / 4=\left[8 \mathrm{M}^{\prime} / \mathrm{n} / \Phi_{2} / \mathrm{K}_{\mathrm{pv}} / \Phi_{2}\right] \mathrm{K}_{\mathrm{ph}} \Phi_{1} \mathrm{l}_{\mathrm{o}}{ }^{3 / 4} \\
& \mathrm{M}_{\mathrm{i}}=\left[8\left(\mathrm{M}_{\mathrm{xy}}-\mathrm{n} \mathrm{M}_{\mathrm{i}} \mathrm{j} / \mathrm{n} / \Phi_{2} / \mathrm{K}_{\mathrm{pv}} / \Phi_{2}\right] \mathrm{K}_{\mathrm{ph}} \Phi_{1} \cdot \mathrm{l}_{\mathrm{o}}^{3 / 4}\right. \\
& \text { By writing } \mathrm{c}=2 / \mathrm{n} / \Phi_{2} / \mathrm{K}_{\mathrm{pv}} / \Phi_{2} \mathrm{~K}_{\mathrm{ph}} \Phi_{1} \mathrm{lo}^{3} \\
& \mathrm{M}_{\mathrm{i}}=\mathrm{M}_{\mathrm{xy}} \mathrm{c} /(1+\mathrm{n} \mathrm{c}) \\
& M^{\prime}=M_{x y}-n M_{1}=M_{x y}[1-n c /(1+n c)] \\
& \mathrm{K} \varphi=\mathrm{M}_{\mathrm{xy}} / \varphi=\mathrm{M}^{\prime} / \mathrm{y}^{\prime} / \mathrm{d}=\Phi_{2} \mathrm{~K}_{\mathrm{pv}} \Phi_{2} \mathrm{n} / 8 / \mathrm{d} \\
& \rightarrow \mathrm{K} \varphi=\Phi_{2} \mathrm{~K}_{\mathrm{pv}} \Phi_{2} \mathrm{n} / 8 \text { when } \mathrm{c} \text { is very large } \\
& \rightarrow Q_{\max }=4 M_{x y} / n / \Phi_{2} / d
\end{aligned}
$$

\section{Then}

When the piles are free-standing

In this case:

$$
\begin{gathered}
\mathrm{d}=1 \\
\mathrm{M}_{\mathrm{i}}=0 \\
\mathrm{Q}_{\max }=4 \mathrm{M}_{\mathrm{xy}} / \mathrm{n} / \Phi_{2}
\end{gathered}
$$

\section{6}

Maximum pile load

Under a central load $Q$, the load per pile equals:

$$
\mathrm{Q}_{\mathrm{p}}=\mathrm{Fz} / \mathrm{n}
$$

Compression will always be complete if $\mathrm{Q}_{\mathrm{p}}>\mathrm{Q}_{\max }$ : - in other words, if we verify that $\mathrm{M}_{\mathrm{xy}} / \mathrm{Fz}<\mathrm{n} \mathrm{d} \Phi_{2} / 4$.

Taking account of the horizontal reaction of the soil on piles when they are embedded:

- increases K $\varphi$;

- reduces tensile/ compressive force;

- increases pile head moments.

\section{3.}

Conclusions for pile design

At SLS, the geotechnical design of piles under tension for $Q_{p}-Q_{\max }$ is to be calculated without taking this horizontal reaction into account.

On the other hand, for pile reinforcements in combined bending and for footing reinforcements, the effect of the horizontal reaction, and hence the $M_{i}$ value, is to be taken into account. 


\section{Construction Measures}

Current regulations and those of chapter 5.1.2 apply and are completed in the following chapters.

\section{3.}

\section{Concrete pile reinforcements}

Concrete piles are reinforced:

- Longitudinally over the height calculated;

- The entire height in the case of a tension-bending moment;

- Transversally in accordance with current regulations.

\section{6.}

\section{Verification and inspection}

Current regulations apply and are completed in the following paragraphs.

\section{5.}

\section{Concrete piles}

The sampling frequency is 1 sample per $100 \mathrm{~m}^{3}$ of concrete installed, with a least 1 sample every 3 days and 1 sample per wind turbine ( 6 specimens per sample).

Concrete characteristics must comply with Standard NF EN 206 and pile-installation standards.

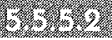

\section{Mat-foundation reinforcements}

The mat foundation is to be designed to take up:

- Fixed-end moments $M_{i}$ if the piles are embedded;

- Moments and shear forces generated by the transmission of compressive forces or potential tension in the piles.

According to the respective stiffness of each pile, which must be justified by the contractor (especially on heterogeneous ground).

\section{r.t.}

\section{Pile Continuity}

The continuity of piles made is to be verified by examining 1 in 8 piles:

- Either using an impedance test;

- Or a rebound (echo) test.

On all piles by recording the boring and concreting parameters.

\section{6}

\section{Hybrid or "Composite" foundations}

The foundation slab is supported by the soil and $n$ piles with a diameter $\Phi_{1}$ and a height $h+L$, which are located over one or more circles with a diameter $\Phi_{2}$ (without a load-transfer platform between the pile heads and foundation slab, unlike the "foundations on rigid inclusions" solution).
The foundation slab is considered to be infinitely rigid.

These piles may or may not be connected to the structure and hence may or may not take up tensile forces. When they are connected to the structure, they are called "hybrid foundations", as defined by O. Combarieu. When they are not connected to the structure, they are called "composite foundations".

They must also be calculated under compression, combined bending and shear, and even under tensile stress when they are connected to the structure.

\section{6)}

\section{Operating principles}

Hybrid or "composite" foundations can be considered in two different ways:

- As a standard foundation on piles: taking account of the footing enables pile size to be reduced, at the cost of a slight increase in the settlement of the overall structure;

- As a direct foundation on the soil, with piles added to limit settlement.

These recommendations apply to these two types of hybrid or "composite" foundations; the number of piles may vary, but the recommendations assume that the footing is infinitely rigid.

This foundation design is only relevant if the soil enables substantial mobilization of force under the footing. Its relevance is limited by at least two conditions:

- Pile tips supported by very resistant soils, and loadtransfer footing supported by very compressible soils;

- Settlement of the soil surface supporting the footing, due to external actions such as embankment work, storage, pumping, etc.

Taking account of the combined mobilization of the piles and soil under the footing can also help optimize the overall design of the foundation slab (smaller piles and foundation slab).

\section{2.}

\section{Description}

The designations "hybrid foundation" or "composite foundation" apply to the entire "footing and pile" structure, which is designed and calculated by taking into account the actual potential for simultaneous mobilization of soil forces by the piles and footing (Combarieu, 1988; Borel, 2005).

Both of these principles are in continuity with the "gravity-base" solution ( $\$ 5.2)$, "gravity-base on rigid inclusions" solution ( $\$$ 5.4) and "deep foundations" solution ( $\S 5.5)$. The fundamental difference from the "gravity-base on rigid inclusions" solution is the absence of a load-transfer platform. Nevertheless, they operate in the same way, by the combined mobilization of soil under the footing and piles. Both the piles and the soil under the footing can therefore be mobilized, provided that their respective load curves and mutual interaction are compatible.

To design this type of system, it is always essential to calculate displacements (finite element or iterative calculations) to model all foundation components. This 
calculation must be carried out for all load cases, so that their respective reactions with the soil and piles can be combined in each case.

This model must use behavior laws developed for various types of ground and all interfaces. It must also be able to describe system behavior over the whole operating range of stress, up to the approach of failure.

Since the soil withstands stresses and deformations in this type of solution, sensitivity studies on soil parameters are always required.

Comment: A structural behavior study is essential for this type of solution. It must take vertical and horizontal stresses and overturning moments into account, as an extension of design methods taking account of central vertical loading (Combarieu, 1988) and horizontal stresses (Borel, 2005).

\section{(5)}

\section{Geotechnical data}

To justify the bearing and calculate settlements and rotation for this type of foundation, remember that the geotechnical data must combine:

- The requirements of chapter 5.1.2 on gravity-bases;

- Specific requirements for pile bearing calculations, namely knowledge of the soil over a height equal to $L$ $+\max \left(5 \mathrm{~m} ; 7 \Phi_{1}\right)$.

Successive geotechnical studies must allow for a standard curve, with all soil parameters as per $\S 4.6 .1$ and 4.6.2 for every homogeneous layer.

The geotechnical engineer must also give the value of $p_{l e}{ }^{*}$ and $q_{c e}$ under the footing, and the short- and long-term $K_{v} K_{x^{\prime}} K_{y^{\prime}} K_{z}$ and $K_{\varphi}$ soil stiffness under this footing. The $G$ values to be taken into account for the calculation in very slight deformation $\left(10^{-3}\right.$ to $\left.10^{-5}\right)$ must be given as part of a geotechnical study.

\section{5)}

Pile justification

\section{Sherenting}

\section{Calculating deformations and load distribution}

Calculating deformations and load distribution is essential for designing hybrid or "composite" foundations.

This calculation is based on relations between unit forces and deformations for the various foundation components. For a load applied to the foundations, the calculation involves determining the forces applied to the footing, lateral surface and pile points respectively, and calculating settlement in the foundation head. In this way, a load-settlement curve can be drawn for the foundations and the level of mobilization for each component in relation to the corresponding ultimate loads or intrinsic pile load can be verified for all load cases (SLS and ULS).

Figure 16 depicts the respective soil and pile settlements according to depth $\mathrm{z}$, for a footing downward displacement depth value $w_{s}(0)$, with the hypothesis that this footing may or may not be compressible.

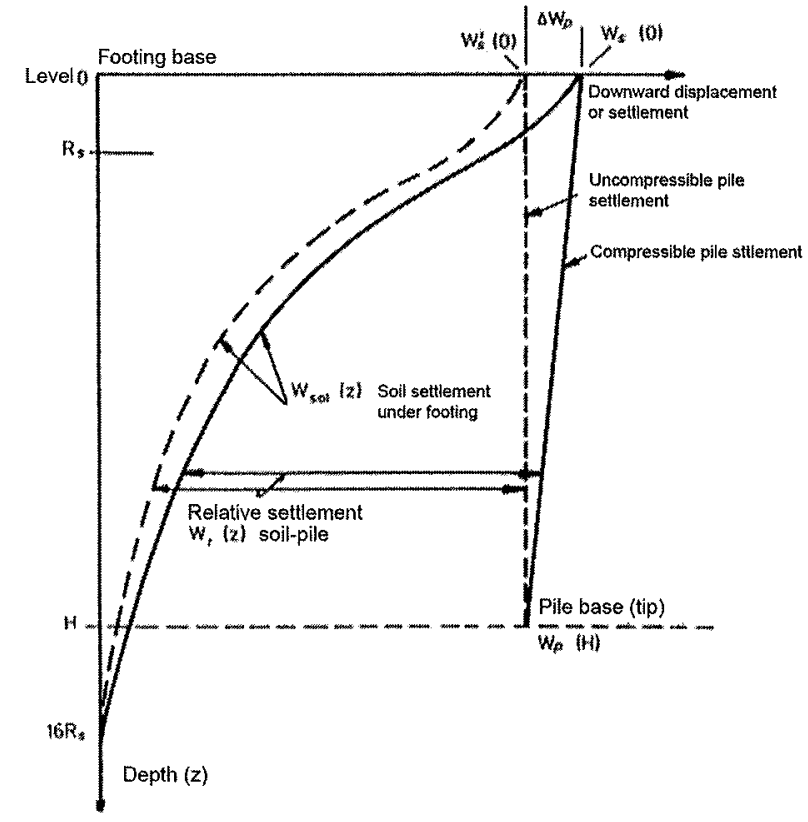

16.16. Soil and foundation settlement.

In the upper section of the piles under the footing, the relative settlement wr $(\mathrm{z})$ is always very low. It is thus advisable to consider that mobilizable friction $t(z)$ over a length $R_{s}=\Phi / 2$ may be disregarded. For the bearing calculation, it is recommended to cancel out this friction over $\mathrm{R}_{\mathrm{s}} / 2$.

The friction mobilized under $\mathrm{R}_{\mathrm{s}} / 2$ is calculated according to the relative pile displacement in relation to the soil.

Pile settlement calculations are carried out in accordance with current regulations, following the method described by Combarieu (1988).

As long as mean tensile stress of the concrete over the tensile section of pile is greater than $\mathrm{f}_{\mathrm{ct}} / \gamma_{\mathrm{s}}$, the only produced pile ES retained for calculating pile elongation when the piles are connected to the structure is the steel one.

Taking account of the cross-coupled stiffness of both components (soil under the footing and piles), as well as the horizontal interaction and applied moment on the slab, requires 3D finite element calculations or iterative calculations, which must highlight:

- friction mobilized along the pile shaft;

- foundation slab rotation;

- mobilized stress in the soil under the footing;

- applied load under compression or under tension for each pile;

- pile heads moments applied to the mat foundation when the piles are embedded in it;

- horizontal stresses applied to each pile.

This model must use behavior laws developed for various types of ground and all interfaces. It must also be able to describe the system's behavior over the whole operational range up to the approach of failure.

\section{5.}

\section{Verifying reinforced soil bearing capacity}

In all SLS and ULS load cases: 
$-\mathrm{S}_{\text {comp }}, \sigma_{\max }, \sigma_{\min }$ and $\mathrm{q}_{\mathrm{ref}}=\left(3 \sigma_{\max }+\sigma_{\min }\right) / 4$ is calculated in accordance with $\S 3.5 .2$. The reaction (positive or negative) of each pile is incorporated using iterative calculations;

- Local and overall bearing capacity requirements described in the following paragraphs must be verified.

Comment: Piles in the completely compressed imaginary soil section as illustrated in Appendix $B$ bear under compression, while all other piles bear under tension if they are connected to the structure.

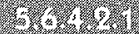

\section{Overall bearing capacity requirement}

The following overall bearing requirement is verified for all SLS and ULS load cases, using:

$$
\begin{gathered}
\mathrm{q}_{\text {soilsLS }}>\left(\mathrm{q}_{\text {refSLS }} \mathrm{S}_{\text {ref }}-\mathrm{n} \mathrm{Q}_{\text {pileSLS }}\right) /\left(\mathrm{S}_{\text {ref }}-\mathrm{nA} \mathrm{A}_{\mathrm{p}}\right), \\
\mathrm{q}_{\text {soilULS }}>\left(\mathrm{q}_{\text {refULS }} \mathrm{S}_{\text {ref }}-\mathrm{n} \mathrm{Q}_{\text {pileULS }}\right) /\left(\mathrm{S}_{\text {ref }}-\mathrm{n} \mathrm{A}_{\mathrm{p}}\right) .
\end{gathered}
$$

The ultimate $Q_{\text {pile }}$ value to consider is defined with reference to the base resistance $R_{b}$ and friction resistance $R_{s}$

$$
\begin{gathered}
Q_{\text {pilesLS }}=\min \left[A_{p} 0.3 f_{c}^{*} ;\left(R_{b} / \gamma_{b}+R_{s} / \gamma_{s}\right)\right] \\
Q_{\text {pileULS }}=\min \left[A_{p} a_{c c} f_{c}^{*} / 1.5 ;\left(R_{b} / \gamma_{b}+R_{s} / \gamma_{s}\right)\right]
\end{gathered}
$$

with pressuremeter or penetrometer methods, the following equations are used respectively:

$$
\begin{gathered}
\mathrm{q}_{\text {soiluLS }}=\mathrm{k}_{\mathrm{p}} \mathrm{p}_{\mathrm{le}} / \gamma_{\text {soiluLS }}+\mathrm{q}_{\mathrm{o}}^{\prime} \text { or } \mathrm{q}_{\text {soiluLS }}= \\
\mathrm{k}_{\mathrm{c}} \mathrm{q}_{\text {ce }} / \gamma_{\text {soilULS }}+\mathrm{q}_{\mathrm{o}}^{\prime} \\
\mathrm{q}_{\text {soilsLS }}=\mathrm{k}_{\mathrm{p}} \mathrm{p}_{\mathrm{le}} / \gamma_{\text {soilsLS }}+\mathrm{q}_{\mathrm{o}}^{\prime} \text { or } \mathrm{q}_{\text {soilsLS }}=\mathrm{k}_{\mathrm{c}} \mathrm{q}_{\mathrm{ce}} / \gamma_{\text {soilSLS }}+\mathrm{q}_{\mathrm{o}}^{\prime}
\end{gathered}
$$
with $\gamma_{\text {soil }}, \gamma_{b}$ and $\gamma_{s}$ in accordance with current regulations.

Comment: The current values are as follows.

\begin{tabular}{cllll}
\hline \multirow{2}{*}{\begin{tabular}{l} 
IAwEX \\
\multirow{2}{*}{ QP SLS }
\end{tabular}} & Suggested safety factors. & & \\
& driven pile & 2.00 & 2.00 & 3.00 \\
& bored pile & 2.80 & 2.00 & 3.00 \\
\hline \multirow{2}{*}{ Rare SLS } & driven pile & 1.57 & 1.57 & 3.00 \\
& bored pile & 2.20 & 1.57 & 3.00 \\
\hline ULS & & 1.40 & 1.40 & 2.00 \\
\hline
\end{tabular}

Additional Information: During verification of the overall bearing capacity by applying the above safety factors, the ultimate values for some of the resistant components (soil under the footing, inclusion friction and pile point) may be reached but not exceeded (partial safety factor of 1 when in operation) when the calculations for stress distribution between the soil and piles are carried out.

Comment: These values are to be updated as soon as the French National Implementation Standard of Eurocode 7 NF $94-262$ is published.

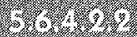

\section{Local bearing capacity requirement}

As stated previously ( $\$ 5.6 .2$ ), the following must be verified for all load cases (SLS and ULS) using iterative load-distribution calculations:

- Local soil-bearing requirement, verified with:

$$
\begin{aligned}
& q_{\text {soilSLS }}>\sigma_{\text {maxSLS }} \\
& q_{\text {soilULS }}>\sigma_{\operatorname{maxULS}}
\end{aligned}
$$

Where $\sigma_{\max }$ is the maximum stress applied to the soil under the footing.

With pressuremeter and penetrometer methods, the following equations are used respectively:

$\mathrm{q}_{\text {soilULS }}=\mathrm{k}_{\mathrm{p}} \mathrm{p}_{\mathrm{le}} / \gamma_{\text {soiluLS }}+\mathrm{q}_{\mathrm{o}}^{\prime}$ or $\mathrm{q}_{\text {soiluLS }}=\mathrm{k}_{\mathrm{c}} \mathrm{q}_{\mathrm{ce}} / \gamma_{\text {soiluLS }}+\mathrm{q}_{\mathrm{o}}^{\prime}$

$\mathrm{q}_{\text {soilsLS }}=\mathrm{k}_{\mathrm{p}} \mathrm{p}_{\mathrm{le}} / \gamma_{\text {soilSLS }}+\mathrm{q}_{\mathrm{o}}^{\prime}$ or $\mathrm{q}_{\text {soilSLS }}=\mathrm{k}_{\mathrm{c}} \mathrm{q}_{\mathrm{ce}} / \gamma_{\text {soilsLS }}+\mathrm{q}_{\mathrm{o}}^{\prime}$

- Verify that stresses for each pile in the system, calculated using iterative load-distribution calculations, remain within allowed limits.

$$
\begin{gathered}
\mathrm{Q}_{\text {pileSLS }}=\min \left[\mathrm{A}_{\mathrm{p}} 0.3 \mathrm{f}_{\mathrm{c}}^{*} ;\left(\mathrm{R}_{\mathrm{b}} / \gamma_{\mathrm{b}}+\mathrm{R}_{\mathrm{s}} / \gamma_{\mathrm{s}}\right)\right] \\
\mathrm{Q}_{\text {pileULS }}=\min \left[\mathrm{A}_{\mathrm{p}} \mathrm{a}_{c c} \mathrm{f}_{\mathrm{c}}^{*} / 1.5 ;\left(\mathrm{R}_{\mathrm{b}} / \gamma_{\mathrm{b}}+\mathrm{R}_{\mathrm{s}} / \gamma_{\mathrm{s}}\right)\right]
\end{gathered}
$$

with $\gamma_{\mathrm{b}}$ and $\gamma_{\mathrm{s}}$ in accordance with current pile regulations.

Additional Information: During verification of the system's overall bearing capacity by applying the above safety factors, the ultimate values for some of the resistant components (soil under the footing, inclusion friction and pile point) may be reached but not exceeded (partial safety factor of 1 when in operation) when the calculations for stress distribution between the soil and piles are carried out.

\section{6.6}

\section{Horizontal Stresses}

When the piles are connected to the structure, horizontal stresses applied per pile are distributed in proportion to their horizontal stiffness.

When the piles are not connected to the structure, horizontal stresses $H_{i}$ are distributed over the piles under compression, in proportion to their vertical loads $N_{i}$ by verifying that $N_{i}^{*} \operatorname{tg} \varphi^{\prime}$ is greater than the horizontal load $H_{1}$ calculated previously, where $\operatorname{tg} \varphi^{\prime}$ concrete $=0.8$.

Comment: Disregarding the soil-footing friction is a safety feature of this mode of operation.

If this calculation in deformation cannot be carried out, the soil involvement can be disregarded. The horizontal stresses are then distributed over the piles alone.

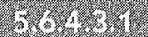

Taking passive soil pressure into account

Passive soil pressure and soil cohesion are generally not taken into account.

Comment: Horizontal stresses beneath the footing underside are thus equal to those applied in the footing head. Nevertheless, when the foundation slab concrete is poured directly into the excavation, the footing passive pressure can be taken into account up to a value determined by the geotechnical engineer, although this must be limited to $30 \%$ of the maximum passive pressure value.

\subsection{0}

\section{Construction measures}

Current regulations and those of chapter 5.1.2 apply and are completed in the following chapters. 
5.

\section{Foundation soil support}

This solution requires the implementation of mitigation measures to protect the bottom of the excavation during construction.

This includes making piles at the bottom of the excavation using a work platform (sub-base layer) suitable for equipment movements.

This sub-base layer will then be used as the foundation soil support, to ensure homogeneous contact between the footing and the soil, thus enabling loads to be transferred from the footing to the soil.

The work platform with a height $\mathrm{H}_{\text {plat }}$ must be installed according to "sub-grade layer" or "road" requirements (LCPC/SETRA 2000a and b), whether they are made of frictional materials (natural gravel) and/or reinforced with binders (cement, lime, etc.).

It is characterized using in-situ "road" or "sub-grade layer" tests (plate bearing tests, etc.), or more standard geotechnical tests (pressuremeter or penetrometer tests), or laboratory tests (CBR or Immediate Bearing Capacity ratio, cohesion measurements, friction angle and water content, etc.).

The aim of these tests is to verify the in-situ compactness of materials and determine their behavior laws by estimating the various common deformation moduli (pressuremeter modulus, if possible, Young's modulus $E$ or oedometric modulus $M$ ), shear characteristics $\left(c^{\prime}, \varphi^{\prime}\right)$ and calculating the settlement and shear strength of this layer.

The soil support's geomechanical characteristics, for example EV2 modulus and platform thickness, vary according to the design study for the foundation system and depend on in-situ soil characteristics.

This distribution layer generally consists of at least $40 \mathrm{~cm}$ of material:

- Natural gravel granular backfill:

- for example, class D1, D2 or D3 or R in accordance with GTR92 (NFP 11-300),

- compacted to 95\% of OPM,

- this gives it a deformation modulus (equivalent to an EV2 modulus) of around $50 \mathrm{MPa}$, an EV2/EV1 ratio $<2.1$, and a friction angle of $40^{\circ}$ for crushed material and $38^{\circ}$ for rolled material;

- For soils treated with binders, the ordinary cohesion characteristics and friction angle to be taken into account for the calculations are $c^{\prime}=50 \mathrm{kPa}$ and $\varphi^{\prime}=25^{\circ}$.

The sub-base layer is to be laid according to professional rules and is subject to standard inspections for the validation of sub-grade layers beneath ground slabs.

Blinding concrete is made as soon as possible after the geotechnical engineer or project manager has validated the work. The sub-base layer must be reconditioned before being covered with this blinding concrete.

It is very important to avoid any disturbance at the bottom of the excavation by taking standard precautions for surfaces (especially for piles in mud, etc.).

To distribute the concentration of foundation-slab peripheral stresses, there must be a load-transfer platform extended over a width corresponding to least the maximum ( $\mathrm{Hmax} / 2 ; 0.5 \mathrm{~m}$ ) beyond the edge of the foundation slab and last row of columns. This is the minimum width to ensure satisfactory compaction.
Construction measures required to ensure that this sub-base layer is not contaminated by the supporting soil are to be implemented (geotextile, anticontamination layer, etc.).

\section{860}

\section{Pile Reinforcement}

Concrete piles are reinforced:

- Longitudinally over the height calculated: at least $4 \mathrm{~m}$; - The entire height in the case of a tension-bending moment;

- Transversally in accordance with current pile regulations.

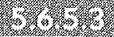

\section{Piles under tensile loads}

Tensile force is not allowed in piles at quasipermanent SLS.

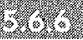

\section{Verification and inspection}

Current regulations and those of $\S 5.1 .2$ apply and are completed in the following chapters.

\section{1.}

\section{Bearing and weathering of the excavation top}

Please refer to $\$ 5.1 .3$.

\section{5.}

Sub-base Layer

\section{7.}

\section{Thickness}

Platform thickness is checked by comparing topographic readings at 3 points per wind turbine.

\section{6)}

Quality

"Sub-grade layer" tests, plate loading, CBR or Immediate Bearing Capacity tests, as well as $\varphi^{\prime}$ and particle-size measurements, are recommended.

Comment: For embankments thicker than $80 \mathrm{~cm}$, a pressuremeter test or CPT can be used.

These tests can be carried out at the following frequencies:

- Bearing tests (a choice between plate loading, $q_{c^{\prime}} p_{1}$ or CBR);

- at least 3 per foundation slab and 3 per construction site,

- Identification (particle size) and/or characterization $\left(\mathrm{C}^{\prime}, \varphi^{\prime}\right)$ tests;

- at least 1 per construction site

Comment: for high-quality natural gravel as characterized above, characterization tests may be dispensed. 


\section{s.}

\section{Mat foundation reinforcements}

The mat foundation is to be designed to withstand:

- Fixed-end moments $\mathrm{M}_{\mathrm{i}}$, of piles when they are embedded in slabs;

- Punching effect of piles in the foundation slab;

- Vertical stresses (compression, tension), moments and shear forces generated by the potential transmission of compressive and tensile stresses to the piles.

Depending on the respective stiffness of each pile and soil under the footing, which is to be justified by the Contractor (especially on heterogeneous ground).

\section{6}

\section{Concrete piles}

The sampling frequency is 1 sample per $100 \mathrm{~m}^{3}$ of concrete installed in the piles, with at least 1 sample every 3 days and 1 sample per site $(6$ specimens per sample).
Concrete characteristics must comply with NF EN 206 and pile installation standards.

\section{(5)}

\section{Shaft integrity}

Shaft integrity of piles is to be checked by testing 1 in every 8 piles:

- Either using an impedance test;

- Or a rebound (echo) test;

- And on all piles by recording the boring and concreting (or injection) parameters in the case of CFA piles, screw piles or micropiles. 


\section{Appendix A (informative)}

\section{Glossary \\ A.1 Geotechnical Action \\ Geotechnical action is defined as the action trans- mitted to the structure by the ground, an embankment, water body or underground water.}

\section{A.2 Operational Load}

The operational load (Standard NF EN 61400 -1) must equal the highest value of:

a) the loads during normal electricity production, taking an average over its life span;

b) the loads during emergency stop for a wind speed chosen to ensure that loads before the stop equal those obtained using a).

\section{A.3 Contracting Authority}

The contracting authority (Law 85-704 \& Standard NFP 94-500) is the legal entity (or natural person) [...] for whom the structure is built. The contracting authority has main responsibility for the structure; this role includes a general interest function that it cannot waive.

\section{A.4 Project Manager}

According to NFP 94-500, the project manager is the legal entity or natural person who designs and/or manages and supervises the installation of the structure on behalf of the contracting authority.

\section{A.5 Technical Supervisor}

See chapters 2.1.2 and 2.2.4.

\section{A.6 Geotechnical Engineer}

The geotechnical engineer (NFP 94-500) is the legal entity or natural person who carries out geotechnical engineering services and/or geotechnical investigations.

\section{A.7 Operator}

The operator is the person who develops a wealthproducing asset.

\section{A.8 Geotechnical study}

Geotechnics (as per NFP 94-500) covers all activities linked to applied soil mechanics, rock mechanics and engineering geology. Geotechnics encompasses the study of soil geotechnical properties, including interactions between the ground and the surrounding structures, and constructing and operating the supplied structure.

Geotechnics focuses mainly on the following earth sciences:

- Geology;

- Hydrogeology;

- Soil and rock mechanics

- Geomaterial rheology;

- Geophysics;

- Geodynamics:

- Geochemistry.

Geotechnical investigations (NFP 94-500) bring together all investigations and surveys carried out using boring ${ }^{(1)}$, sounding ${ }^{(2)}$ and measuring equipment, as well as in situ and laboratory geotechnical tests. These are used to gather geological and geotechnical information about a site's soil and rock conditions. This includes their nature, composition, structure and spatial distribution, as well as their physical, chemical, geomechanical and hydrogeological characteristics. There is a whole range of tests for geotechnical investigations (See Standards NF P 94- Soils: surveying and tests, and Eurocode 7 NF EN 1997-2).

\section{A.9 Project Management}

The project management assignment (Law 85704), which may be entrusted to a private law entity or group of private law entities by the contracting authority, must supply the project with an architectural, technical and economic response [...]. When building a structure, the project management assignment is distinct from the contractor's assignment.

\section{A.10 Technical Inspection}

See chapters 2.1.2 and 2.2.4.

\section{A.11 Miscellaneous}

Geotechnical structures (Standard NFP 94-500) are structures (or parts of a structure) ensuring the transfer of interactions between the overall structure and ground in which it stands. Although non-exhaustive, the most common examples of geotechnical structures are:

- Foundations (footings, mat foundations, wells, piles, supporting-wall units, buried walls, etc.);

- Support structures made using any process (prefabricated walls, diaphgram walls, shotcrete, inclusions, ground nailing, reinforced earth, etc.);

- Earth structures (using aggregate from the site or elsewhere) and ground modifications via earthworks, undercutting, dredging (bank sloping, slope modification, quarrying, embankments, sub-grade layers, dikes, dams, etc.);

- Underground structures, with or without support structures (wells, excavations, galleries, tunnels, storerooms, etc.);

- Drainage, dewatering and pumping structures, etc.

A geotechnical report (Fascicle 62, Article A.2.2 [MELT, 1993], Standard NF P94-500) is drawn up on the basis of the completed tests and local experience of the ground gained from previous construction work and various types of assignment.

Soil (NFP 94-500) [...] is the generic term used by geotechnical engineers to define any natural or artificial ground liable to be mobilized when a structure is built. The term encompasses in-situ and backfill soil and rocks. It is completely different from the ordinary literal sense of the word, which designates only the ground surface. The rest of the soil (sub-soil) consists first of a superficial layer with variable thickness (soil in the agricultural or pedological sense), which results from the weathering of underlying rock. The next layer consists of minerals in the earth's crust, which are rocks in the geological sense of the word.

\footnotetext{
(1) Boring (NFP 94-500): carrying out a linear excavation using a specific boring tool and procedure.

(2) Sounding (NFP 94-500): local, methodical exploration of ground via an excavation, bore hole, probe insertion or using physical techniquos that cause little or no damage. This is to determine the nature and structure of the ground or measure its physical, chemical, mechanical or hydraulic properties
} 


\section{Appendix B}

Development of the " $q_{\text {ref }}$ calculation: definition of the "half-moon" and $S_{\text {ref }}$

B.1. Influence of $\%$ footing completely compressed on maximum soil bearing pressure

For the settlement of a footing subject to eccentric vertical stress $V$, the compressed surface area and average stress applied to this surface must be determined.

The formulae for square or rectangular footings do not apply to circular footings (see the shape of the compressed zone, which is hatched on the drawing below).

The formulae below enable reduction to an equivalent rectangular footing $\mathrm{b}^{\prime} \times 1^{\prime}$ subject to average stress $\sigma_{\mathrm{m}}$.
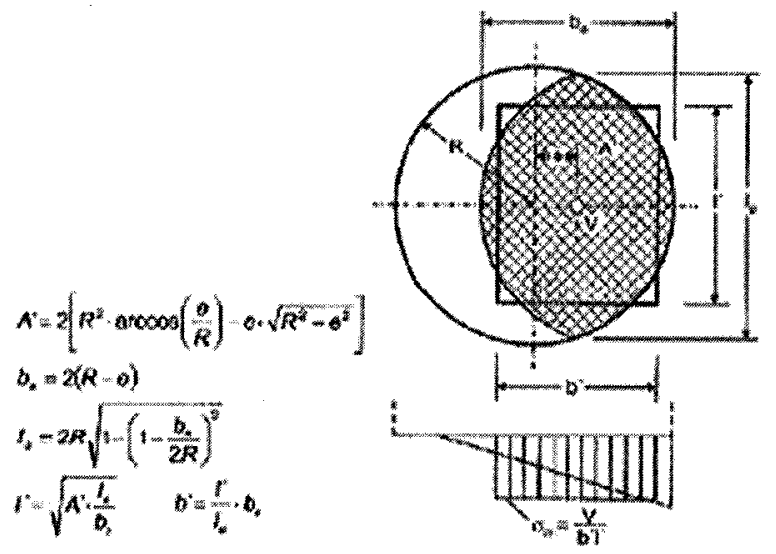

\section{Hicinger 8}

For a wind turbine subject to torque $\left(\mathrm{M}_{\mathrm{ULS}} ; \mathrm{F}_{\mathrm{zULS}}\right)$, the reference surface area $S_{\text {ref }}$ is the hatched zone in the figure above (half-moon: limited by two symmetrical circular arcs in relation to an axis at $\mathrm{e}=\mathrm{M}_{\mathrm{ULS}} / \mathrm{F}_{\mathrm{zULS}}$ from the center of the wind turbine).

\section{B.2. Definition of the completely compressed zone}

\begin{tabular}{|c|c|c|c|c|}
\hline 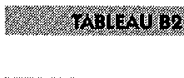 & $\begin{array}{l}\text { Stress u } \\
\text { according }\end{array}$ & $\begin{array}{l}\text { a rec } \\
\text { Navier's }\end{array}$ & $\begin{array}{l}\text { gular } \\
\text { odel. }\end{array}$ & dation ba \\
\hline 81 & & & & $\begin{array}{l}\text { Compreressed } \\
\text { surveredied }\end{array}$ \\
\hline \multirow{2}{*}{$\begin{array}{l}\text { Rectangular* } \\
\text { (BL) }\end{array}$} & $0 \leq e_{n} \leq \frac{B}{6}$ & $\frac{F}{B d}\left(1+6 \frac{e^{2}}{B}\right)$ & $\frac{r}{B D}\left(1-6 \frac{v_{x}^{2}}{B}\right)$ & BL \\
\hline & $\frac{B}{6} \leq e_{3} \leq \frac{B}{2}$ & $\frac{y}{B H} \frac{4}{\sqrt{\left(1-2 \frac{D A}{B}\right)}}$ & 0 & $1,5\left(1-2 \frac{C}{B}\right)$ \\
\hline
\end{tabular}

B.3. Reduction factor $i_{e}$, owing to load eccentricity in the case of a foundation under eccentric vertical load

When the diagram for normal stresses applied to the ground by a foundation is determined in accordance with E.3.6, the bearing reduction factor for taking load eccentricity into account must be calculated using the following expression:

In this expression:

$V_{d}$ is the design value for the vertical component of the action result

$A$ is the total surface area of the foundation base

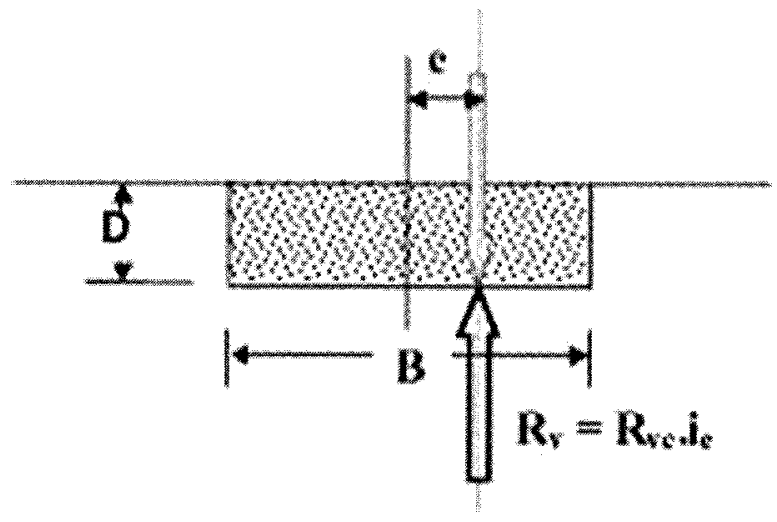

10.10

B.4. Definition of the compressed surface area $S_{\text {comp }}$ and reference surface area $S_{\text {ref }}$

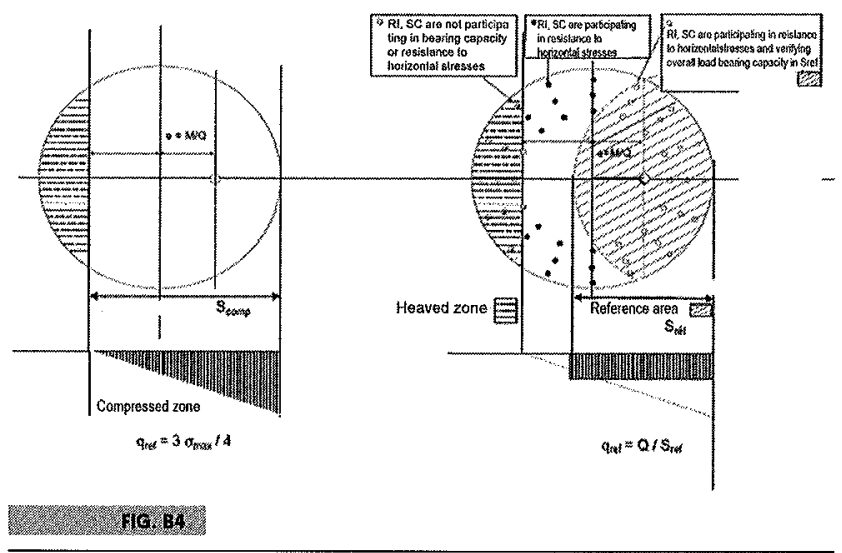




\section{Appendix C}

Degradation curves for $\mathrm{G}$ according to distortion: extracts from the French PS92 Regulations giving orders of magnitude for $V_{s}$

\section{C.1. For Clayey material}

Modulus Degradation Curve (Vucetic \& Dobry, 1991)

Madulus Degradation Curve (Seed et al., 1984)
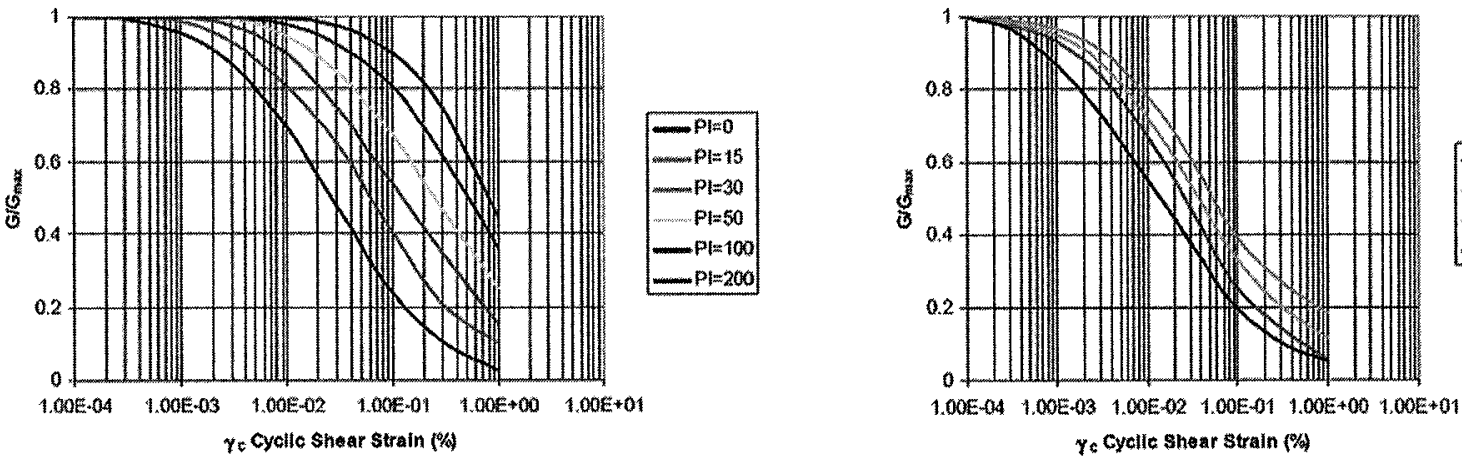

\section{C.2. For Granular Material}

Table 5.2.1 of standard NFP 06013 [PS92 regulations].

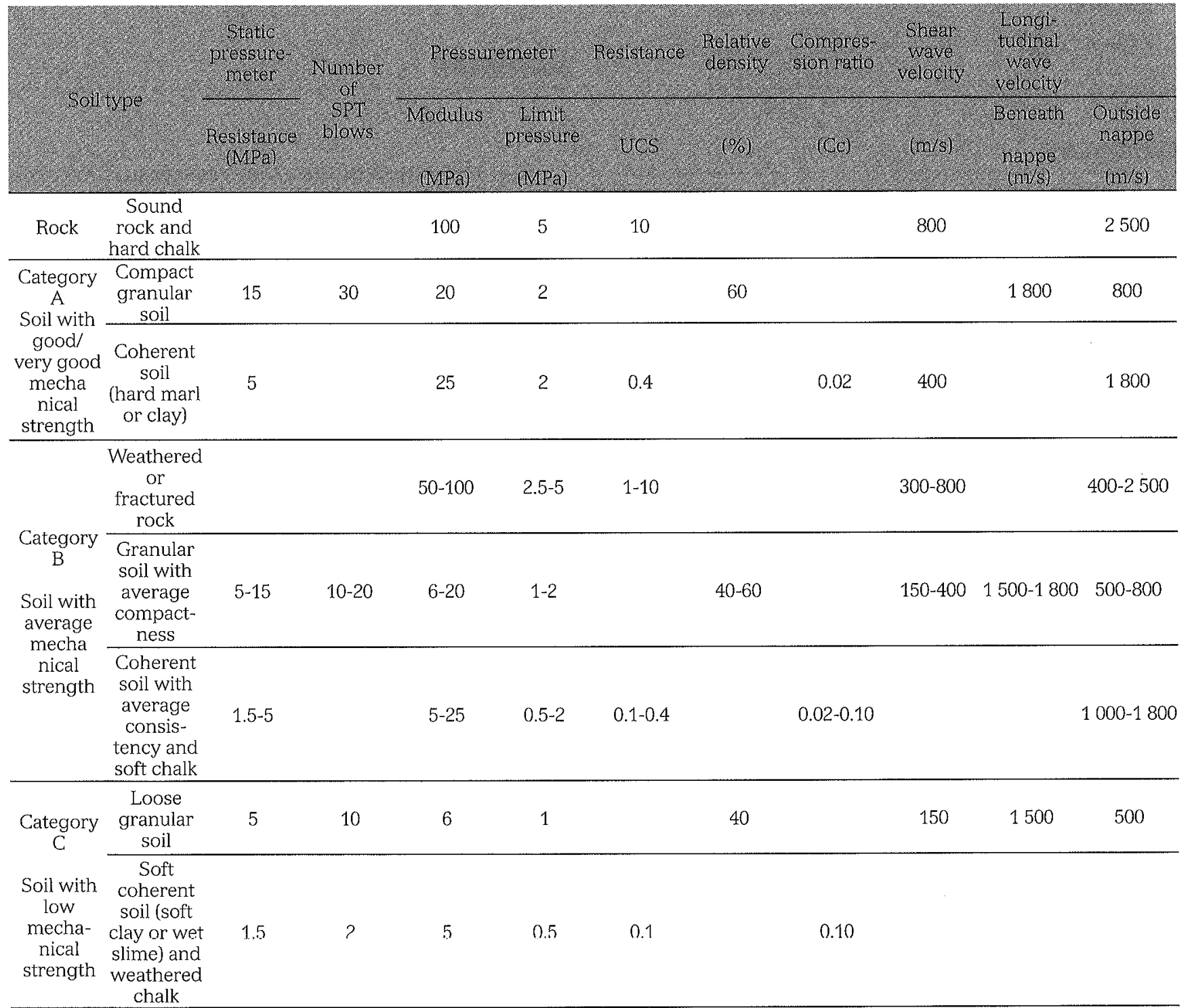




\section{Appendix D}

\section{Calculating $p_{l e}$ according to the imaginary foot- ing method}

TARLEAU bi Calcul de $p_{\mathrm{le}}$ selon la méthode de la semelle fictive.

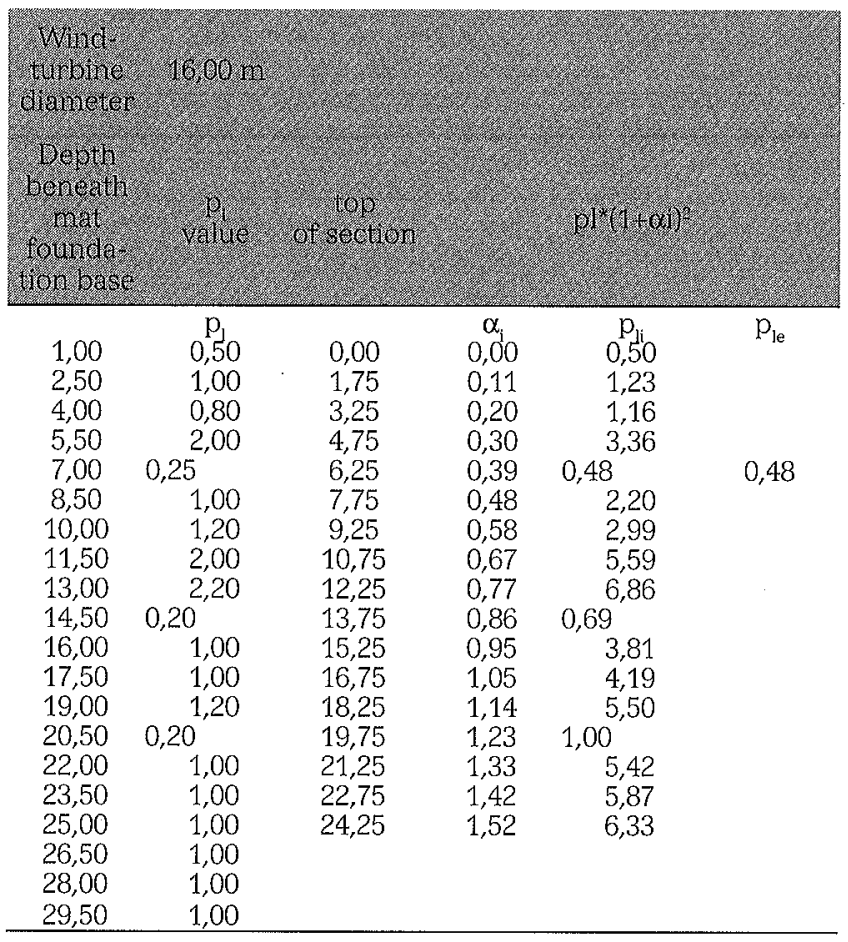

Note: If a second value of $0.25 \mathrm{MPa}$ is measured at a depth of $8.5 \mathrm{~m}$, the corresponding value of $p_{l i}$ will equal 0.55 lower than the value of 0.48 calculated for $p_{1}$ of $0.25 \mathrm{MPa}$ measured at a depth of $7 \mathrm{~m}$.

NB: A third value of $0.25 \mathrm{MPa}$ at a depth of $10 \mathrm{~m}$ also corresponds to a higher $p_{l i}$ value $(0.61 \mathrm{MPa})$. The layer thickness characterized by $p_{1}=0.25 \mathrm{MPa}$ will thus not influence the $p_{l e}$ calculation. On the other hand, this thickness has a crucial role in calculating settlement.

\section{Appendix E}

Table of $f_{\text {cvd }}$ values

(see below)

To use the following table, we take $f_{c k}=f_{c}^{*}$

UNREINFORCED OR SLIGHTLY REINFORCED CONCRETE STRUCTURES

\begin{tabular}{|c|c|c|c|c|c|c|c|c|c|}
\hline 4 & fod & $I_{\mathrm{gs}}$ & $\operatorname{tentaxes}$ & fetad & $\operatorname{led} d l_{0}$ & 6 & $\theta$ & 8 & $4 a_{0 x}$ \\
\hline & $0,8+0.10$ & $0.3 y c k$ & $0.7 \mathrm{tcm}$ & 11 & & & & & \\
\hline 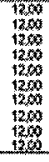 & 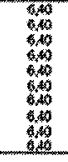 & 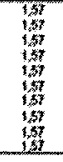 & 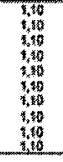 & 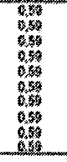 & 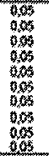 & 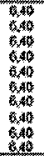 & 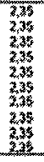 & 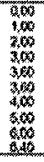 & 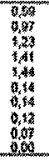 \\
\hline 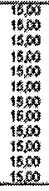 & 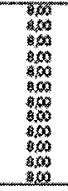 & 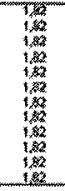 & 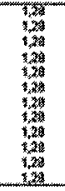 & 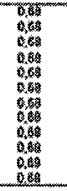 & 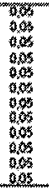 & 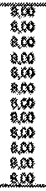 & 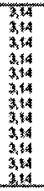 & 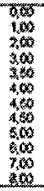 & 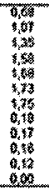 \\
\hline 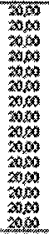 & 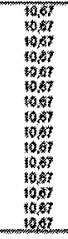 & 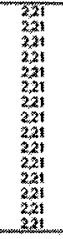 & 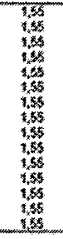 & 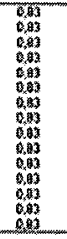 & 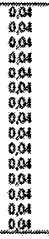 & 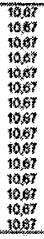 & 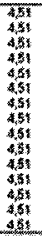 & 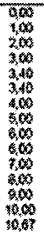 & 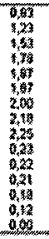 \\
\hline 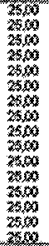 & 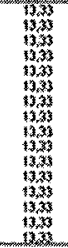 & 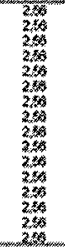 & 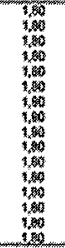 & 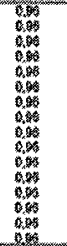 & 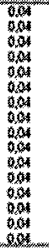 & 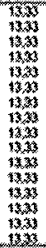 & 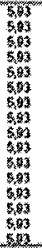 & 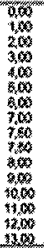 & 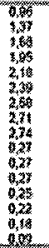 \\
\hline
\end{tabular}

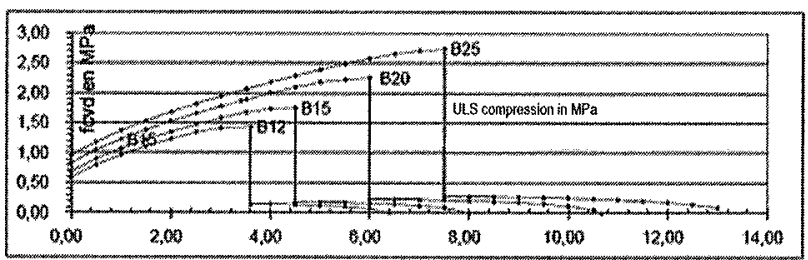

16.16 


\section{References}

\section{Geotechnical survey}

DTU 11.1. - Sondage des sols de fondation. Revue française de géotechnique, décembre 1968.

XP P94-010 - Sols : reconnaissance et essais - Glossaire géotechnique - Définitions Notations - Symboles. (Soils: investiga tion and testing. Geotechnical glossary - Definitions - Notations - Symbols)r 24 p., 1996.

Baguelin F - Rapport du sous-comité Symboles, Unités, Définitions. Comptes rendus du $I X^{c}$ congrès international de Mécanique des Sols et des Travaux de Fondations, Tokyo, 1977, p. 153-170.

Park, C.B., Miller, R.D., Xia, J, - Multichannel analysis of surface waves : Geophysics, v. 64, n³, 1999, p. 800-808.

LCPC - Paramètres de forage en géotechnique. Méthode d'essai ME79, 2010, 54 p.

Norme NF P94-113 - Sols : reconnaissance et essais - Essai de pénétration statique. Soil: Investigation and testing - Cone penetration test, $1996,16 \mathrm{p}$

Norme NF P11-300 - Classification des matériaux utilisables dans la construction des remblais et des couches de forme d'infrastructures routières, 1992, 21 p.

Norme NF P94-074 - Sols : reconnaissance et essais - Essai à l'appareil triaxial de révolution, 1994.

Norme NF P94-110-1 - Sols : reconnaissance et essais - Essai pressiométrique Ménard. Partie 1 : essai sans cycle. (Soil: Investigation and testing - Ménard pressure meter test - Part 1: Test without unload-reload cycle), 2000, $45 \mathrm{p}$.

XP P94-110-2 - Sols : reconnaissance et essais - Essai pressiométrique Ménard - Partie 2 : essai avec cycle. (Soil: Investigation and testing - Ménard pressuremeter test - Part 2: Test with unload - Reload cycle) 1999,8 p

NF P94-157-1 - Sols : reconnaissance et essais - Mesures piézométriques - Partie 1 : tube ouvert. (Soils: Investigation and testing. In situ pore pressure measurement. Part 1: Piezometric tube), $1996,12 \mathrm{p}$.

NF P94-157-2 - Sols : reconnaissance et essais - Mesures piézométriques - Partie 2 : sonde de mesure de pression interstitielle. (Soils: Investigation and testing. In situ pore pressure measurement. Part 2: Pore pressure meter) 1996, $16 \mathrm{p}$.

Norme NF EN ISO 22475-1 - Reconnaissance et essais géotechniques - Méthodes de prélèvement et mesurages piézométriques - Partie 1 : principes techniques des travaux. (Geotechnical investigation and testing - Sampling methods and groundwater measurements - Part 1: Technical principles for execution), 2007, $135 \mathrm{p}$.

XP P94-202 - Sols : reconnaissance et essais - Prélèvement des sols et des roches - Méthodologie et procédures. Soil: investigation and testing. Soil sampling. (Methodology and procedures), 1995, $44 \mathrm{p}$.

NF EN ISO 22476-3 - Reconnaissance et essais géotechniques - Essais en place - Partie 3 : essai de pénétration au carottier. (Geotechnical investigation and testing - Field testing - Part 3: Standard penetration test), $2005,18 \mathrm{p}$.
Techniques Louis Ménard Règles d'utilisation des techniques pressiométriques et d'exploitation des résultats obtenus pour le calcul des fondations. Brochure D60, 1965

Norme NF EN 1997-1 - Eurocode 7, calcul géotechnique, partie I : règles générales. Eurocode 7 : geotechnical design Part 1: General rules), 2005, 145 p.

Norme NF EN 1997-1/NA - Eurocode 7 Calcul géotechnique - Partie 1 : règles générales - Annexe nationale à la NF EN 1997-1:2005. (Eurocode 7 - Geo technical design - Part 1: General rules - National annex to NF EN 1997-1:2005) 2006, $10 \mathrm{p}$.

Norme NF EN 1997-2 - Eurocode 7 : calcu géotechnique - Partie 2 : reconnaissance des terrains et essais. (Eurocode 7: Geo technical design - Part 2: Ground investigation and testing), 2007, $174 \mathrm{p}$.

LCPC/SETRA - Réalisation des remblais et des couches de forme. Guide technique. Fascicule I Principes généraux ( $2^{\mathrm{e}}$ ed.) Réf. D9233-1, LCPC, ISBN 2110857072 2000, 98 p.

LCPC/SETRA 2000. Réalisation des remblais et des couches de forme. Guide technique. Fascicule II. Annexes techniques (2e ed.). Réf. D9233-2, LCPC, ISBN $2110857080,102 \mathrm{p}$

Document Technique Unifié DTU 13.11 Fondations superficielles (norme DTU P11-211). Contract bill for superficial foundations, contract bill of the special clauses, 198814 p. + Modificatif 1 de 1997.

Document Technique Unifié DTU 13.12 Règles pour le calcul des fondations superficielles (norme DTU P11-711). Rules for the calculation of superficial foundations, $1988,18 \mathrm{p}$

Norme P11-212 - DTU 13.2 - Travaux de bâtiment - Travaux de fondations profondes pour le bâtiment - Partie 2 : Cahier des clauses spéciales (Référence commerciale des normes $\mathrm{P} 11-212$ et NF P11-212-2), 1994, $86 \mathrm{p}$.

Norme NFP 94-500 - Missions d'ingénierie géotechnique - Classification et spécifications, Geotechnical engineering missions - Classification and specifications, $2006,38 \mathrm{p}$.

MELT (Ministère de l'Équipement, du Logement et des Transports) - Cahier des clauses techniques générales applicables aux marchés de travaux, Fascicule $n^{\circ} 62$, titre $V$ \& Règles techniques de calcul et de conception des fondations des ouvrages de génie civil m. Textes officiels, $n^{\circ} 93-3,1993,182$ p. Cet ouvrage a égale ment été édité par Eyrolles en 1999.

Norme NF P03-100 - Critères généraux pour la contribution du contrôle technique à la prévention des aléas techniques dans le domaine de la construction. General criteria for the contributionof the technical inspection towards the prevention of technical risks in the construction field, $1995,20 \mathrm{p}$

Durand F. - CFMS, oct. 2009.

\section{Wind turbines}

DIBT - Richtlinie für Windenergieanlagen. Deutches Institut für Bautecknik, Berlin. Directive allemande sur le dimensionnement des éoliennes, 2004, 45 p.
ISO 4354:1997 - Actions du vent sur les structures. Wind actions on structures, 1997, $52 \mathrm{p}$

Norme NF EN 61400 -1 - Éoliennes-partie 1 : exigences de conception. (Wind turbines - Part 1), 2006, $93 \mathrm{p}$

Norme NF EN 1991-1-4/NA - Eurocode 1 Actions sur les structures - Partie 1-4 actions générales - Actions du vent - Annexe nationale à la NF EN 1991-14:2005 - Actions générales - Actions du vent. (Eurocode 1: Actions on structures - Part 1-4: General actions - Wind actions - National annex to NF EN 1991-14:2005 - General actions - Wind actions), 2008, $42 \mathrm{p}$

NF EN 1991-1-4 - Eurocode 1 : actions sur les structures - Partie 1-4 : actions générales - Actions du vent. (Eurocode 1: Actions on structures - Part 1-4: gereral actions - Wind actions), 2005, $124 \mathrm{p}$.

Norme CEI 61400-2 - Aérogénérateurs Partie 2 : exigences en matière de conception des petits aérogénérateurs (Wind turbines - Part 2: Design require ments for small wind turbines), 2006, $188 \mathrm{p}$.

NF EN 60034-14 - Machines électriques tournantes - Partie 14 : vibrations mé caniques de certaines machines de hauteur d'axe supérieure ou égale à $56 \mathrm{~mm}$ - Mesurage, évaluation et limites de l'intensité vibratoire. (Rotating electrical machines - Part 14: Mechanical vibration of certain machines with shaf heights $56 \mathrm{~mm}$ and higher - Measurement, evaluation and limits of vibration severity), 2004, $17 \mathrm{p}$.

NF EN 60034-14/A1 - Machines électriques tournantes - Partie 14: vibrations mécaniques de certaines machines de hauteur d'axe supérieure ou égale à $56 \mathrm{~mm}$ - Mesurage, évaluation et limites de l'intensité vibratoire. (Rotating electrical machines - Part 14: Mechanical vi bration of certain machines with shaft heights $56 \mathrm{~mm}$ and higher - Measurement, evaluation and limits of vibration severity), 2007, 5 p.

\section{Other standard references}

NF X02-006 - Normes fondamentales. Le système international d'unités. Description et règles d'emploi - Choix de multiples et de sous-multiples. (Fundamen tal standards. The international systems of units. Description and rules for use. Choice of multiples and sub-multiples) 1994, $28 \mathrm{p}$.

ISO 2394: 1998 - Principes généraux de la fiabilité des constructions. (General principles on reliability for structures), $1998,79 \mathrm{p}$.

ISO $14688-1$ and $14688-2$

ISO $14689-1$ and $14689-2$

\section{Papers}

Berthelot P. Lamadon Th. - Vérification des fondations d'éoliennes. Document Bureau Veritas Powerpoint. Stage CC $100 \mathrm{~F}, 28$ nov. 2007, 50 p.

Berthelot P., Lamadon Th. - Eoliennes. Re connaissance géotechnique et principes de tondations. Document Bureau Veritas, nov. 2007, $16 \mathrm{p}$.

Berthelot P., Frossard A., Glandy M. - Rigid inclusions : Calculation parameters and 
reception criteria for the distribution layer-ISSMGE, Mexico, 2006.

Berthelot P., Durand F., Frossard A., Glandy M. - Dallages et modules de déformation des couches de sol ; application aux renforcements de sols par inclusions et analyse du comportement du matelas de repartition. $14^{\mathrm{e}}$ Congrès européen, $\mathrm{Ma}$ drid, 2007

Berthelot P., Durand F., Glandy M. - Méthode analytique du comportement d'un matelas de répartition au-dessus d'inclusions rigides et supportant ou non une structure en béton. $15^{\mathrm{e}}$ Congrès européen, Athènes, 2011.

Bustamante M., Grau Ph., Le Kouby A - Cas des éoliennes. Document powerpoint présenté à la journée CFMS du $7 / 4 / 06$ ( sollicitations cyclique et fatigue des matériaux ), 2006, $46 \mathrm{p}$.

Faber T. - Offshore Wind Energy in Europe - Actual Situation and Future Develop ments Proceedings of the Sixteenth International Offshore and Polar Engineering Conference. Lisbon, Portugal, July 1-6, 2007

Frank R. - Fondations profondes. Techniques de l'Ingénieur. C248, 1996, 45 p.

Frank R., Zhao S.R. - Estimation par les paramètres pressiométriques de l'enfoncement sous charge axiale des pieux forés dans les sols fins. Bull. Liai son Labo P. et Ch. N ${ }^{\circ} 119$, mai-juin 1982 p. $17-24$.

Frossard A., Glandy M. - Justification d'une fondation superficielle sur un sol renforcé d'inclusions. Annales ITBTP, février 2002.

Houlsby G.T., Kelly R.B., Huxtable J., Byrne B.W. - Field trials of suction caissons in clay for offshore wind turbine foundations. Géotechnique 55, $\mathrm{n}^{\circ} 4$ 2005, 287-296

Sieffert J. G., Cevaer F. - Manuel des fonc tions d'impédance. Fondations superficielles. Ouest Editions, Presses académiques, 1992, 174 p.

\section{Legislative texts}

Décret $n^{\circ}$ 93-1164 du 11 octobre 1993 relatif à la composition du cahier des clauses techniques générales applicables aux marchés publics de travaux et approuvant ou modifiant divers fascicules.

Loi $n^{\circ} 2005-781$ du 13 juillet 2005 de programme fixant les orientations de la politique énergétique.

Décret 91-1147 relatif aux Demandes de Renseignements (DR) concernant les réseaux existants et la liste des concessionnaires.

\section{Technical inspection}

Article L. 111-23 du Code de la construction et de l'habitation, Partie législative, Livre $I^{\text {er }}$ : Dispositions générales. Titre Ier : Construction des bâtiments. Chapitre Ier : Règles générales. Section 7 : contrôle technique. Modifié par ordonnance $n^{\circ}$ 2005-658 du 8 juin $2005-$ Art. 4 JORF 9 juin 2005
Article L. 111-24 à 26 du code de la construction et de l'habitation.

Article R 111-38 du Code de la construction et de l'habitation, Partie réglementaire Livre $I^{\text {er }}$ : Dispositions générales. Titre Ier : Construction des bâtiments. Chapitre

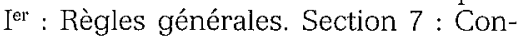
trôle technique. Sous-section 2 : Contrôle technique obligatoire. Modifié par Décret $n^{\circ} 2007-1327$ du 11 septembre 2007 - Art. 2 JORF 12 septembre 2007 en vigueur le $1^{\text {er }}$ octobre 2008.

Articles R 11-27 à 37 et 111-39 à 42 du code de la Construction et de l'Habitation.

Décret $n^{\circ}$ 2007-1727 du 7 décembre 2007 relatif à l'extension du contrôle technique obligatoire à certaines constructions exposées à un risque sismique et modifiant le code de la construction et de l'habitation.

Loi $n^{\circ} 78-12$ du 4 janvier 1978 relative à la responsabilité et à l'assurance dans le domaine de la construction (loi Spinetta).

Loi $n^{\circ} 2008-735$ du 28 juillet 2008

Décret no 78-1146 du 7 décembre 1978 Agrément des contrôleurs techniques.

NF P03-100 - Critères généraux pour la contribution du contrôle technique à la prévention des aléas techniques dans le domaine de la construction. General criteria for the contribution of the technical inspection towards the prevention of technical risks in the construction field, $1995,20 \mathrm{p}$

Loi $n^{\circ} 83-440$ du 2 juin 1983 Donnant force de loi à la $1^{\text {re }}$ partie (législative) du code de la construction et de l'habitation et modifiant certaines dispositions de ce code. Art. 2 (V) (modification de la loi Spinetta).

\section{Earthquakes}

Norme NF P06-013 - Règles de construction parasismique - Règles PS applicables aux bâtiments, dites règles PS 92 . Earthquake resistant construction rules. Earthquake resistant rules applicable to buildings, called PS 92, 1995, $218 \mathrm{p}$

\section{Miscellaneous}

Article 121-3 du Code pénal, Partie législative, Titre II : De la responsabilité pénale. Chapitre Ier : Dispositions générales. Modifié par la loi no 2000-647 du 10 juillet 2000 , art. 1 JORF 11 juillet 2000.

Article 1792-1 du Code civil, Livre III : Des différentes manières dont on acquiert la propriété. Titre VIII : Du contrat de louage, Chapitre III : Du louage d'ouvrage et d'industrie. Section 3 : Des devis et des marchés.

Article 2270 du Code civil (au sujet de la garantie décennale)

Décret $n^{\circ}$ 95-20 du 9 janvier 1995 pris pour l'application de l'article L. 111-11-1 du code de la construction et de l'habitation et relatif aux caractéristiques acoustiques de certains bâtiments autres que d'habitation et de leurs équipements.

Décret $n^{\circ}$ 2007-1327 du 11 septembre 2007 relatif à la sécurité et à l'accessibilité des établissements recevant du public et des immeubles de grande hauteur, modifiant le code de la construction et de l'habitation et portant diverses dispositions relatives au code de l'urbanisme.

Loi $n^{\circ} 85-704$ du 12 juillet 1985 relative à la maîtrise d'ouvrage publique et à ses rapports avec la maîtrise d'ceuvre privée.

Loi $n^{\circ}$ 2003-699 du 30 juillet 2003 relative à la prévention des risques technologiques et naturels et à la réparation des dommages.

Décret $n^{\circ}$ 2004-554 du 9 juin 2004 relatif à la prévention du risque d'effondrement de cavités souterraines et de marnières et modifiant le décret $n^{\circ} 90-918$ du 11 octobre 1990 relatif à l'exercice du droit à l'information sur les risques majeurs.

Article L. 241-1 et 2 - Code des assurances sur l'assurance de responsabilité obligatoire des travaux de bâtiment.

Article L. 242-1 et 2 - Code des assurances sur l'assurance de dommages obligatoire des travaux de bâtiment.

Article L. 243-1 à 8 - Code des assurances sur l'assurance obligatoire des travaux de bâtiment.

Code de l'environnement - Partie législa tive-Livre V : Prévention des pollutions, des risques et des nuisances. Titre $V$ : Dispositions particulières à certains ouvrages ou installations. Chapitre III : Éoliennes.

\section{Other documents}

Philipponnat G. - Paramètres dynamiques du sol. Fondations et ouvrages en terre. Eyrolles, 1997, p. 379-382.

Baugrunddynamik - DGGT, Berlin, 2002

Grundbau-Taschenbuch (Part 1, chapter 1.8 , section 4.2 , picture 38 ).

Cahiers des charges techniques particuliers des différents constructeurs.

Combarieu O. - Calcul d'une fondation mixte, semelles-pieux, sous charge verticale centrée - Note d'information technique LCPC, 1988.

Annales Bâtiment Travaux Publics ( Soulèvement de fondation ), oct.-nov. 1998.

CFMS (Comité Français de Mécanique des Sols et de géotechnique) - Recom mandations sur la conception, le calcul l'exécution et le contrôle des colonnes ballastées sous bâtiments et ouvrages sensibles au tassement. Revue française de géotechnique $\mathrm{n}^{\circ} 111,2011,16 \mathrm{p}$.

USG - Recommandations sur les investigations géotechniques pour la construc tion. Le Moniteur $n^{\circ} 5325$ - 16 décembre 2005. XP P 94-010 (1996), Sols : recon naissance et essais - Glossaire géotechnique - Définitions - Notations - Symboles, décembre, AFNOR

NF X02-006 - Normes fondamentales. Le système international d'unités. Description et règles d'emploi - Choix de multiples et de sous-multiples, 1994.

AFNOR - Présentation des rapports. Recommandation aux auteurs, 1991, 4 p. 